\title{
SUMMARY OF WATER-RESOURCES ACTIVITIES OF THE U.S. GEOLOGICAL SURVEY IN TEXAS--FISCAL YEARS 1989-92
}

Compiled by Kristy E. Uzcategui U.S. GEOLOGICAL SURVEY

Open-File Report 93-112 


\section{U.S. DEPARTMENT OF THE INTERIOR}

BRUCE BABBITT, Secretary

U.S. GEOLOGICAL SURVEY

Dallas L. Peck, Director

For additional information write to:

District Chief

U.S. Geological Survey

8011 Cameron Road, Building A

Austin, TX 78754-3898
Copies of this report can be purchased from:

U.S. Geological Survey

Books and Open-File Reports Section

Denver Federal Center

Box 25425

Denver, CO 80225-0046 
Message from the District Chief

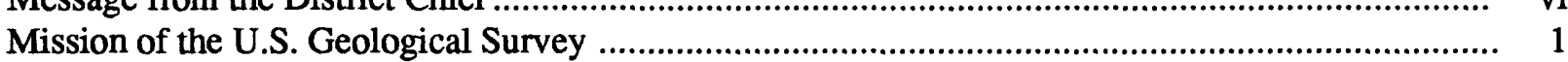

Mission and program of the Water Resources Division.................................................................... 2

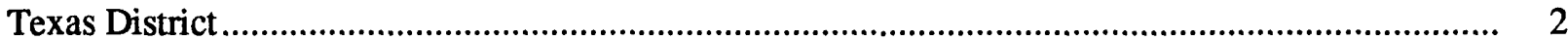

Cooperating agencies......................................................................................................... 6

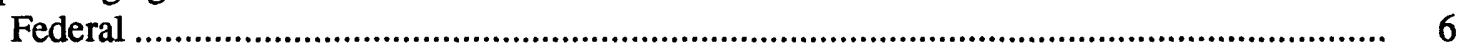

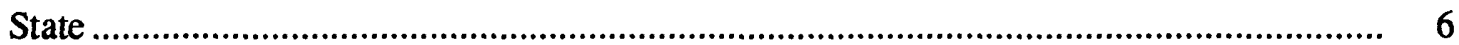

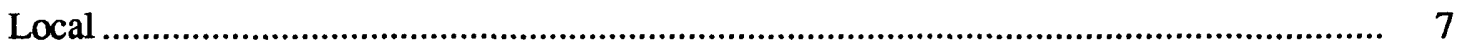

Water-resources data-collection stations and programs............................................................. $\quad 8$

TX 00-001 Surface-water stations ....................................................................................... 9

TX 00-002 Ground-water stations ......................................................................... 11

TX 00-003 Water-quality stations ................................................................................... 13

TX 00-004 Sediment stations.................................................................................... 15

TX 84-005 National Trends Network for monitoring atmospheric deposition..................... 16

TX 78-007 Water use ............................................................................................... 17

Hydrologic investigative and research programs ............................................................. 18

TX 65-028 Urban hydrology study in the Houston metropolitan area ............................... 19

TX 82-075 West Gulf Coast Regional Aquifer-System Analysis (RASA)--

Texas aquifer systems and ground-water atlas of the United States--

Chapter E: Texas and Oklahoma................................................................................. 20

TX 83-080 Solute-transport modeling of ground water in the Hueco

bolson, El Paso-Fort Bliss area............................................................................. 22

TX 83-082 Near-real-time flood routing along Cypress Creek, Harris County................... 23

TX 84-083 Potential impact of diversions of the Trinity River on the water quality of Lake Houston, Texas--Phase I, Prediversions ........................................ 24

TX 84-084 Sources and inflow of nutrients into Lake Lewisville ....................................... 25

TX 85-090 Edwards-Trinity Regional Aquifer-System Analysis (RASA) .......................... 26

TX 85-094 Hydrologic controls affecting ground-water movement in the vicinity of the freshwater/saline-water interface in the Edwards aquifer, San Antonio Region....................................................................................... 28

TX 86-095 Effects of ground-water development in Fort Bend County ............................. 29

TX 86-096 Ground-water contribution of salinity in the upper Colorado River .................. 30

TX 86-097 National lake summary .................................................................................. 31

TX 86-098 Limestone hydrology of the Edwards aquifer, San Antonio area..................... 32

TX 86-101 Geohydrology of the water resources of Oak Spring,

Big Bend National Park

TX 87-102 Kelly Air Force Base installation restoration program, phase II, stage 3

TX 87-103 Trends in water-quality data in Texas........................................................... 35

TX 87-104 Water surface and flow pattern of a major flood at the

Texas Highway 43 crossing of the Sabine River ............................................................. 36

TX 87-105 Current and historical hydrologic conditions of the Edwards-

Trinity aquifer and Comanche Springs, Pecos County.

TX 88-107 Analysis of specific flow paths in the Edwards aquifer,

San Antonio region.

TX 88-108 Monitoring ground-water levels in the High Plains of Texas ........................... 39

TX 88-112 Community structure of aquatic organisms in the

San Antonio River. 
TX 89-113 Study of the saline zone of the Edwards aquifer, San Antonio region.

TX 89-116 Light attenuation and its effects on the quality of water in turbid reservoirs.

TX 89-117 Study of recharge to the Chicot and Evangeline aquifers northwest of Houston.

TX 89-118 Evaluation of methods to calculate irrigated crop acreages using remote-sensing data in Uvalde, Medina, and western Bexar Counties

TX 90-120 Urban hydrology and impacts of water reuse in San Antonio

TX 90-122 Characteristics of salinity in Lake Kemp.

TX 90-123 Renovation of tertiary-treated municipal wastewater by migration through the Hueco bolson aquifer, El Paso.

TX 90-125 Assessment of the potential effects of high-salinity waters on the Highland Lakes

TX 90-126 Streamflow discharges to the Gulf of Mexico.

TX 91-127 National Water Quality Assessment (NAWQA):

Trinity River Basin Study Unit

TX 91-128 Geology and hydrology of the Edwards aquifer in the

Uvalde and Knippa area, Uvalde County

TX 91-129 Statistical and graphical summary of selected water-quality

data from Buffalo Bayou, Houston

TX 91-130 Evaluation of potential bridge scour in Texas.

TX 91-131 Hydrogeologic mapping of the Edwards aquifer recharge zone, Hays and Comal Counties

TX 91-132 Nonpoint-source contamination and eutrophication

of the Sandy Creek Embayment of Lake Travis

TX 91-133 Flood-flow characteristics for selected watersheds in the West Fork Trinity River Basin.

TX 91-134 Estimation of artificial recharge from retention structures

in the Edwards aquifer Recharge Zone near San Antonio.

TX 91-135 Evaluation of the effects of rangeland management practices on water quality and quantity in the Seco Creek Basin near San Antonio.

TX 91-136 Trends in bacteria and nutrient concentrations in tributaries of the North Bosque River, Erath and Hamilton Counties, 1991-94

TX 91-137 Trends in bacteria and nutrient concentrations in tributaries to

Lake Fork Reservoir, Hopkins, Rains, and Wood Counties, 1991-94

TX 91-138 Agricultural and chemical contamination of a shallow aquifer system in north-central Texas.

TX 91-139 Determination of quality of urban storm-water runoff

in the Dallas-Fort Worth Metroplex.

TX 91-140 Ground-water quality monitoring program, Corps of Engineers

Channel Work, Shreveport, Louisiana to Daingerfield, Texas

TX 91-141 Regionalization of flood characteristics in Texas

TX 91-142 Storm-water investigations in the San Antonio metropolitan area.

TX 92-143 Distribution of mercury in sediments in Lavaca and Matagorda

Bays, Calhoun County.

Reports published or approved for publication in fiscal years 1989-92 ........................................ 75

Where to obtain U.S. Geological Survey publications 


\section{ILLUSTRATIONS}

PLATE

Map showing location of active surface-water data-collection stations in Texas-fiscal year 1992

In pocket

\section{FIGURE}

Figure 1. Organizational chart of the Texas District. 


\section{MESSAGE FROM THE DISTRICT CHIEF}

The Water Resources Division of the U.S. Geological Survey has neither regulatory nor developmental authority. Instead, this Division has the principal responsibility within the Federal Government for providing hydrologic information and appraising the Nation's water resources. Hydrologic information and results of water-resources appraisals done by the Survey are made available equally to all interested parties and contribute to descriptions of the location, quantity, quality, and use of water resources and to predictions of the effects of water development on the future availability and quality of water supplies. Planners and managers use this information to locate, design, and operate water-supply facilities such as reservoirs, well fields, and water-treatment plants; to identify effective strategies for protecting the quality of water resources from contamination by toxic or noxious wastes and for locating, designing, and operating waste-disposal facilities; and to allocate available water resources on the bases of court decrees, interstate compacts, international treaties, and water law.

Texas is not without major water-quantity and water-quality problems. Rapid industrialization and population growth have resulted in steadily increasing water requirements and water-quality problems. In much of the State, available storage capacity in existing surface-water reservoirs is barely sufficient to meet water demands during critical droughts. Extensive development of ground water has resulted in severe problems in some areas. In the Texas High Plains, the rate of water use from the High Plains aquifer of the Ogallala Formation greatly exceeds the rate of natural recharge. In the Houston-Galveston area, large-scale pumpage of ground water has resulted in land-surface subsidence. In the HoustonGalveston area and some other areas, large-scale pumpage also is increasing the potential for saline-water intrusion.

Within the constraints of diminishing Federal and State funds, the Texas District of the Water Resources Division is striving to maintain an adequate water-resources data-collection program and to strengthen the investigative program in order to address the priority water-resources issues and problems in the State.

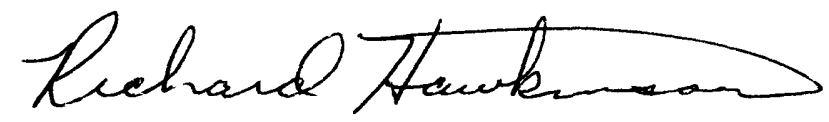

Richard O. Hawkinson

District Chief

U.S. Geological Survey

Austin, Texas 


\title{
SUMMARY OF WATER-RESOURCES ACTIVITIES OF THE U.S. GEOLOGICAL SURVEY IN TEXAS--FISCAL YEARS 1989-92
}

\author{
Compiled by Kristy E. Uzcategui \\ MISSION OF THE U.S. GEOLOGICAL SURVEY
}

The U.S. Geological Survey (USGS) was established by an act of Congress on March 3, 1879, to provide a permanent Federal agency to conduct the systematic and scientific classification of the public lands and to examine the geological structure, mineral resources, and products of national domain. An integral part of that original mission includes publishing and disseminating the earth science information needed to understand, to plan the use of, and to manage the Nation's energy, land, mineral, and water resources.

Since 1879, the research and fact-finding role of the USGS has grown and been modified to meet the changing needs of the Nation it serves. As part of that evolution, the USGS has become the Federal Government's largest earth-science research agency, the Nation's largest civilian mapmaking agency, the primary source of data on the Nation's surface- and ground-water resources, and the employer of the largest number of professional earth scientists. Today's (1992) programs serve a diversity of needs and users. Programs include:

- Conducting detailed assessments of the energy and mineral potential of the Nation's land and offshore areas.

- Investigating and issuing warnings of earthquakes, volcanic eruptions, landslides, and other geologic and hydrologic hazards.

- Conducting research on the geologic structure of the Nation.

- Studying the geologic features, structure, processes, and history of the other planets of our solar system.

- Conducting topographic surveys of the Nation and preparing topographic and thematic maps and related cartographic products.

- Developing and producing digital cartographic data bases and products.

- Collecting data on a routine basis to determine the quantity, quality, and use of surface and ground water.

- Conducting water-resources appraisals in order to describe the consequences of alternative plans for developing land and water resources.

- Conducting research in hydraulics and hydrology and coordinating all Federal water-data acquisition.

- Using remotely sensed data to develop new cartographic, geologic, and hydrologic research techniques for natural resources planning and management.

- Providing earth-science information through an extensive publications program and a network of public access points.

Along with its continuing commitment to meet the growing and changing earth-science information needs of the Nation, the USGS remains dedicated to its original mission to collect, analyze, interpret, publish, and disseminate information about the natural resources of the Nation--providing "earth science in the public service."1

${ }^{1}$ Source: Adapted (and updated December 1984) from U.S. Geological Survey Yearbook for Fiscal Year 1983. 


\section{MISSION AND PROGRAM OF THE WATER RESOURCES DIVISION}

The mission of the Water Resources Division is to provide the hydrologic information and understanding needed for the optimum utilization and management of the Nation's water resources for the overall benefit of the people of the United States.

This is accomplished, in large part, through cooperation with other Federal and non-Federal agencies by:

- Collecting, on a systematic basis, data needed for the continuing determination and evaluation of the quantity, quality, and use of the Nation's water resources.

- Conducting analytical and interpretive water-resource appraisals describing the occurrence, availability, and the physical, chemical, and biological characteristics of surface and ground water.

- Conducting supportive basic and problem-oriented research in hydraulics, hydrology, and related fields of science to improve the scientific basis for investigations and measurement techniques and to understand hydrologic systems sufficiently well to quantitatively predict their response to stress, either natural or manmade.

- Disseminating the water data and the results of these investigations and research through reports, maps, computerized information services, and other forms of public releases.

- Coordinating the activities of Federal agencies in the acquisition of water data for streams, lakes, reservoirs, estuaries, and ground water.

- Providing scientific and technical assistance in hydrologic fields to other Federal, State, and local agencies, to licensees of the Federal Power Commission, and to international agencies on behalf of the Department of State. ${ }^{2}$

\section{TEXAS DISTRICT}

Water-resources activities in Texas include the systematic collection, analysis, and interpretation of hydrologic data, evaluation of water demands, and water-resources research. This report describes the activities of the Water Resources Division of the U.S. Geological Survey in Texas for fiscal years 198992 (October 1989 to September 1992).

The U.S. Geological Survey's activities related to water resources in Texas are under the general direction of Richard O. Hawkinson, District Chief. The Texas District office is located at 8011 Cameron Road, Austin, Texas [zip code: 78754-3898]. The program is executed by professional, technical, and administrative staffs in the District office at Austin; Subdistrict offices at Fort Worth, Houston, and San Antonio; Project office at El Paso; and Field Headquarters offices at Austin, San Angelo, and Wichita Falls. An organizational chart of the Texas District is shown in figure 1.

\footnotetext{
2Source: Adapted from the mission statement by the Chief Hydrologist, September 28, 1984.
} 


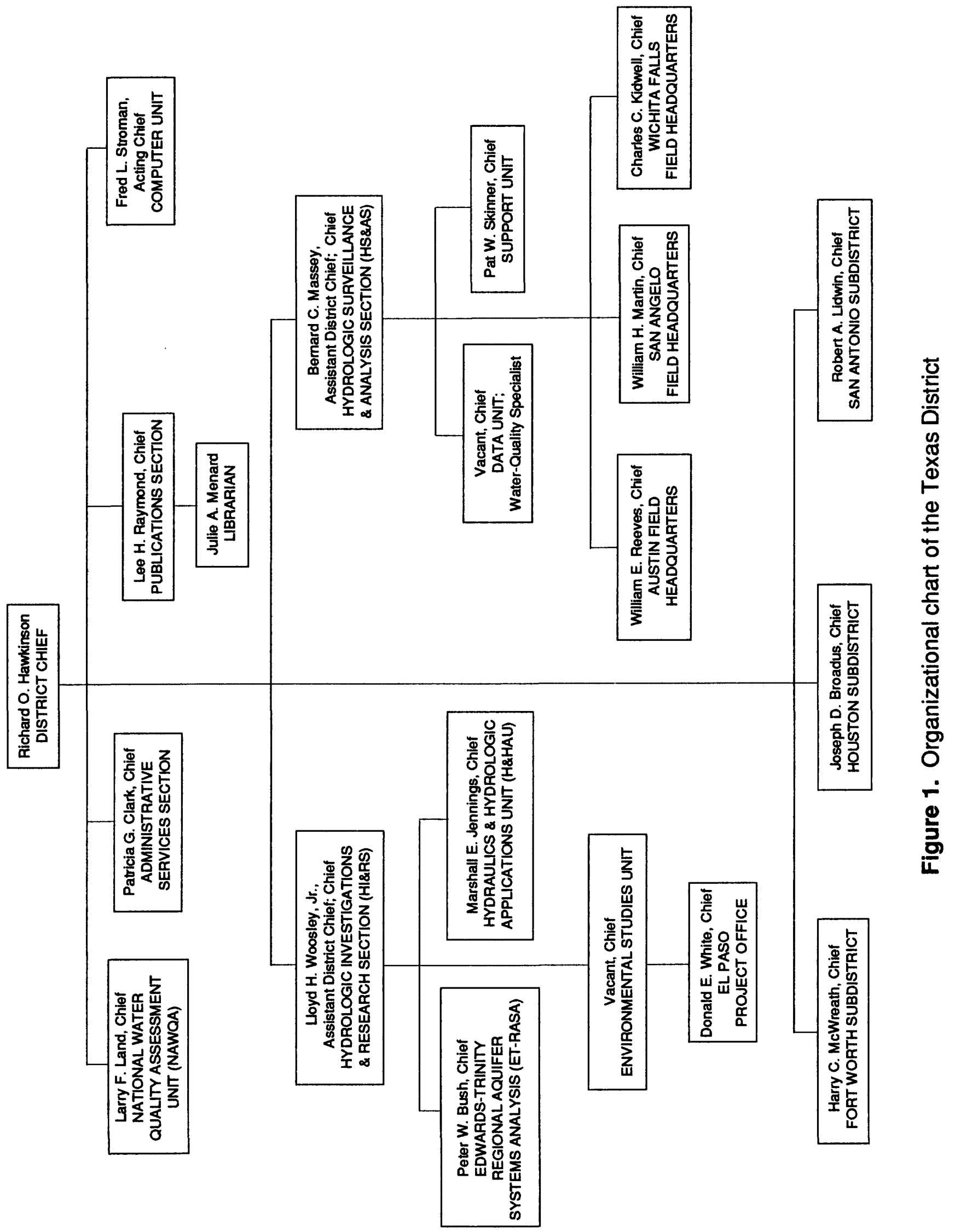


Copies of published and unpublished records, hydrologic data, and some reports may be requested from or through the District office. Information regarding provisional records of stream discharge prior to publication and other hydrologic data collected within their respective areas may be obtained from the Subdistrict offices in Fort Worth, Houston, and San Antonio, the Project office in El Paso, and the Field Headquarters offices in Austin, San Angelo, and Wichita Falls. Requests for information should be addressed as follows:

Joseph D. Broadus

Subdistrict Chief

U.S. Geological Survey

Water Resources Division

2320 La Branch Street, Room 1112

Houston, TX 77004-1099

Telephone: (713) 750-1655

Patricia G. Clark

Administrative Officer

U.S. Geological Survey

Water Resources Division

8011 Cameron Road

Austin, TX 78754-3898

Telephone: (512) 873-3049

Marshall E. Jennings

Chief, Hydrologic and Hydraulics Unit

U.S. Geological Survey

Water Resources Division

8011 Cameron Road

Austin, TX 78754-3898

Telephone: (512) 873-3068

Larry F. Land

Chief, NAWQA

U.S. Geological Survey

Water Resources Division

8011 Cameron Road

Austin, TX 78754-3898

Telephone: (512) 873-3005

William H. Martin

Chief, Field Headquarters

U.S. Geological Survey

Water Resources Division

1409 Knickerbocker Road

San Angelo, TX 76904-5515

Telephone: (915) 655-0616
Peter W. Bush

Project Chief, Edwards-Trinity RASA

U.S. Geological Survey

Water Resources Division

8011 Cameron Road

Austin, TX 78754-3898

Telephone: (512) 873-3055

Richard O. Hawkinson

District Chief

U.S. Geological Survey

Water Resources Division

8011 Cameron Road

Austin, TX 78754-3898

Telephone: (512) 873-3000

Charles C. Kidwell

Chief, Field Headquarters

U.S. Geological Survey

Water Resources Division

318-320A Federal Building

Wichita Falls, TX 76301-3430

Telephone: (817) 766-4052

Robert A. Lidwin

Subdistrict Chief

U.S. Geological Survey

Water Resources Division

435 Isom Road, Suite 234, North Plaza

San Antonio, TX 78216-5149

Telephone: (512) 229-4390

Bernard C. Massey

Assistant District Chief

U.S. Geological Survey

Water Resources Division

8011 Cameron Road

Austin, TX 78754-3898

Telephone: (512) 873-3042 
Harry C. McWreath

Subdistrict Chief

U.S. Geological Survey

Water Resources Division

P.O. Box 6976

Fort Worth, TX 76115-0976

Telephone: (817) 334-5551

Lee H. Raymond

Chief, Publications Section

U.S. Geological Survey

Water Resources Division

8011 Cameron Road

Austin, TX 78754-3898

Telephone: (512) 873-3013

Pat W. Skinner

Lead Hydrologic Technician

U.S. Geological Survey

Water Resources Division

8011 Cameron Road

Austin, TX 78754-3898

Telephone: (512) 873-3044

Vacant

Chief, Data Unit

U.S. Geological Survey

Water Resources Division

8011 Cameron Road

Austin, TX 78754-3898

Telephone: (512) 873-3024

Donald E. White

Hydrologist

U.S. Geological Survey

Water Resources Division

1154 Hawkins Boulevard

El Paso, TX 79925-6437

Telephone: (915) 591-9834
Julie A. Menard

Librarian

U.S. Geological Survey

Water Resources Division

8011 Cameron Road

Austin, TX 78754-3898

Telephone: (512) 873-3020

William E. Reeves

Chief, Austin Field Unit

U.S. Geological Survey

Water Resources Division

8011 Cameron Road

Austin, TX 78754-3898

Telephone: (512) 873-3027

Fred L. Stroman

Computer Programmer/Analyst

U.S. Geological Survey

Water Resources Division

8011 Cameron Road

Austin, TX 78754-3898

Telephone: (512) 873-3066

Vacant

Chief, Environmental Studies Unit

U.S. Geological Survey

Water Resources Division

8011 Cameron Road

Austin, TX 78754-3898

Telephone: (512) 873-3000

Lloyd H. Woosley, Jr.

Assistant District Chief

U.S. Geological Survey

Water Resources Division

8011 Cameron Road

Austin, TX 78754-3898

Telephone: (512) 873-3043 


\section{Cooperating Agencies}

The collection of water-resources data and the conduct of interpretive hydrologic investigations are accomplished in cooperation with Federal, State, and local agencies. Those agencies cooperating with the Texas District of the U.S. Geological Survey in fiscal year 1992 are:

\section{Federal}

Federal Emergency Management Agency

International Boundary and Water Commission, United States and Mexico,

U.S. Section, Amistad and Falcon Reservoirs

Technical Management Team, Lavaca Bay

U.S. Department of Commerce

National Oceanic and Atmospheric Administration

U.S. Department of Defense

Department of the Air Force

Occupational and Environmental Health Laboratory

Air Training Command

Kelly Air Force Base

Wright-Patterson Air Force Base

Department of the Army

Fort Bliss, Texas

Corps of Engineers

Fort Worth, Texas

Galveston, Texas

Tulsa, Oklahoma

Vicksburg, Mississippi

U.S. Department of Agriculture

Soil Conservation Service

U.S. Department of the Interior

Bureau of Reclamation

Fish and Wildlife Service

National Park Service

U.S. Environmental Protection Agency

State

Pecos River Commission

Sabine River Compact Administration

Texas Department of Transportation (formerly Texas State Department of Highways and Public

Transportation)

Texas General Land Office

Texas State Parks and Wildlife Department

Texas State Soil and Water Conservation Board

Texas Water Development Board

University of Texas at Austin 
Local

Cities of:

Abilene

Fort Stockton

Lubbock

Arlington

Fort Worth

Nacogdoches

Austin

Gainesville

Runaway Bay

Carrollton

Garland

Corpus Christi

Georgetown

San Angelo

Dallas

Graham

El Paso

Houston

Barton Springs/Edwards Aquifer Conservation District, Austin

Bexar-Medina-Atascosa Counties Water Improvement District No. 1, Natalia

Brazos River Authority, Waco

Coastal Water Authority, Houston

Colorado River Municipal Water District, Big Spring

Dallas Public Works Department

Dallas Water Utilities Department

Edwards Underground Water District, San Antonio

El Paso Public Service Board

Fort Bend County

Fort Bend Subsidence District

Franklin County Water District, Mount Vernon

Galveston County, Galveston

Greenbelt Municipal and Industrial Water Authority, Clarendon

Guadalupe-Blanco River Authority, Seguin

Harris County Flood Control District, Houston

Harris-Galveston Coastal Subsidence District, Friendswood

High Plains Underground Water Conservation District

Lavaca-Navidad River Authority, Edna

Lower Colorado River Authority, Austin

Lower Neches Valley Authority, Beaumont

North Central Texas Council of Governments, Arlington

North Central Texas Municipal Water Authority, Munday

North Texas Municipal Water District, Wylie

Northeast Texas Municipal Water District, Hughes Springs

Orange County Commissioners Court

Red Bluff Water Power Control District, Pecos

Red River Authority, Wichita Falls

Sabine River Authority of Texas, Orange

Sabine River Compact

San Antonio Department of Environmental Management

San Antonio Department of Wastewater Management

San Antonio Public Service Board

San Antonio Public Works Department, Environmental Development Services

San Antonio River Authority

San Antonio Water Board

San Antonio Water Systems, Water Reuse

(formerly Alamo Water Reuse and Conservation District)

San Jacinto River Authority, Conroe 
Somervell County Water District

Tarrant County Water Control and Improvement District No. 1, Fort Worth

Titus County Fresh Water Supply District No. 1, Mount Pleasant

Trinity River Authority, Arlington

Upper Guadalupe River Authority, Kerrville

Upper Neches River Municipal Water Authority, Palestine

West Central Texas Municipal Water District, Abilene

Wichita County Water Improvement District No. 2

\section{Water-Resources Data-Collection Stations and Programs}

Hydrologic data-collection stations at selected locations throughout Texas are used by the Geological Survey to collect records of stream discharge and stage, lake and reservoir stage, ground-water levels, well and spring discharge, quality of surface and ground water, precipitation, and suspended sediment loads. Each year, new stations are added and others are terminated; thus, the Water Resources Division has a current and historic file of hydrologic data for the State. All data collected are stored in the U.S. Geological Survey National Water Information System (NWIS) and WATSTORE (National Water Data Storage and Retrieval System) and are available on request. These data can be retrieved in machinereadable form or in the form of computer-printed tables or graphs, statistical summaries, and digital plots. Local assistance in the acquisition of information from NWIS and WATSTORE can be obtained from the District Chief in Austin, Texas.

Locations of active (fiscal year 1992) surface-water data-collection stations are shown on plate 1. In addition to the surface-water data-collection stations, the U.S. Geological Survey operates precipitation stations, ground-water level recorders, and daily and intermittent sediment stations. Hydrologic data often are collected for brief periods of time in support of investigative studies, are published in interpretive reports, and are not included in the continuing programs.

The International Boundary and Water Commission, United States and Mexico, operates all streamflow-gaging stations on the Rio Grande and near the mouth of its principal tributaries at and downstream from El Paso, Texas. Records collected at these stations are published in an annual bulletin by the Commission and may be obtained from the Intemational Boundary and Water Commission, U.S. Section, P.O. Box 20003, El Paso, TX 79998.

Continuing hydrologic data-collection programs are summarized in the following pages. Location maps are shown. The summaries include reports proposed during 1989-92 and current (1992) reports. Reports that have been published or approved during 1989-92 are listed in a separate section at the end of this report. 
PROJECT TITLE: Surface-Water Stations

PROJECT NUMBER: TX 00-001

STUDY LOCATION: Statewide

COOPERATING

AGENCY: Multi-agency

PROJECT CHIEF: Bernard C. Massey, District Office, Austin

PROJECT DURATION: Continuous since 1915

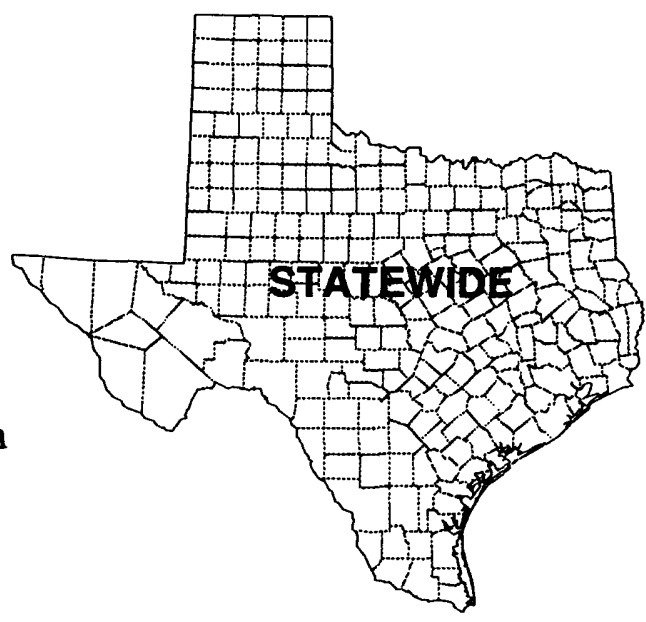

PROBLEM: Under the continuing surface-water data program, involving many Federal, State, and local agencies, data are collected for use in surveillance, planning, design, hazard warning, operation, and management in water-related fields such as water supply, hydroelectric power, flood control, irrigation, bridge and culvert design, bridge scour, wildlife management, pollution abatement, flood-plain management, and water-resources development. Data are collected for current purposes such as assessments, compact and legal requirements, and research or hydrologic studies. The program also supports studies to define the statistical properties of, and trends in, surface water.

OBJECTIVES: A. To collect surface-water data sufficient to satisfy needs for use in the (1) assessment of water resources, (2) operation of reservoirs or industries, (3) forecasting, (4) disposal of wastes and pollution controls, (5) discharge data to accompany water-quality measurements, (6) compact and legal requirements, and (7) research or special studies. B. To collect data necessary for use in analytical studies that define statistical properties of, and trends in, surface water and for use in planning and design.

APPROACH: Partial-record gaging is used instead of complete record gaging where needed. The adequacy of the hydrologic network is reviewed annually and modified as necessary to meet data needs and funding constraints. Surface-water records are computed on a continuing basis, and the data are published annually.

PROGRESS: Hydrologic data at continuous-record and partial-record surface-water stations in Texas were collected as scheduled. The report, "Water resources data, Texas," was published in three volumes each for water years 1988, 1989, and 1990, and in four volumes for water year 1991.

PLANS: Collect hydrologic data at the existing streamflow and reservoir gaging-station network as scheduled. Prepare and publish data for the 1992 water year. Answer information requests as necessary.

\section{PROPOSED REPORTS:}

Buckner, H.D., and Shelby, W.J., Index of surface-water stations in Texas, January 1991: U.S. Geological Survey Open-File Report.

Water resources data, Texas, water year 1992, Volume 1. Arkansas River Basin, Red River Basin, Sabine River Basin, Neches River Basin, Trinity River Basin, and intervening coastal basins: U.S. Geological Survey Water-Data Report for Texas. 
Water resources data, Texas, water year 1992, Volume 2. San Jacinto River Basin, Brazos River Basin, San Bemard River Basin, and intervening coastal basins: U.S. Geological Survey WaterData Report for Texas.

Water resources data, Texas, water year 1992, Volume 3. Colorado River Basin, Lavaca River Basin, Nueces River Basin, Rio Grande Basin, and intervening coastal basins: U.S. Geological Survey Water-Data Report for Texas. 
PROJECT TITLE: Ground-Water Stations

PROJECT NUMBER: TX 00-002

STUDY LOCATION: Statewide

COOPERATING

AGENCIES: City of Austin; City of Georgetown; City of Houston;

Colorado River Municipal Water District; Edwards

Underground Water District; El Paso Public Service Board;

Harris-Galveston Coastal Subsidence District; High Plains

Underground Water Conservation District; Orange County

Commissioners Court; Sabine River Authority; San Antonio

Water Board; Texas Water Development Board; U.S. Bureau of

Reclamation; U.S. Department of the Air Force, Kelly Air Force

Base; U.S. Department of the Army, Corps of Engineers, Fort

Worth, Texas; U.S. Department of the Army, Fort Bliss, Texas

PROJECT CHIEF: Frank C. Wells, District Office, Austin

PROJECT DURATION: Continuous since October 1929

PROBLEM: Water levels in wells, discharge of springs and wells, and water-quality data are key characteristics in monitoring ground-water conditions and trends. The continuing hydrologic data from local subprojects TX 00-00210 (Austin ground water), TX 00-00230 (El Paso ground water), TX 0000250 (Houston ground water), TX 00-00251 (subsidence, Houston area), TX 00-00252 (Orange County ground water), TX 00-00270 (San Antonio ground water) are collected, compiled, and reported under project TX 00-002, ground-water data program. Also included in this program, but not described in detail, are short-term and limited data-collection and investigative activities. These include ground-water conditions at Fort Bliss and the characteristics of the shallow aquifer in the El Paso area.

OBJECTIVE: To provide for the compilation and preparation for publication of data collected from several ground-water studies done by the U.S. Geological Survey in Texas and from records collected from the Statewide observation well program maintained by the Texas Water Development Board.

APPROACH: Water levels in certain key observation wells are measured monthly. These data and others from U.S. Geological Survey programs in Texas and from the Texas Water Development Board are prepared for publication in the "Water resources data, Texas" report and in the U.S. Geological Survey 5-year report on the water levels in observation wells in the selected areas.

PROGRESS: Continuous, daily, and periodic water-quality data were collected at the network of streams and reservoir sites in Texas as scheduled. The hydrologic data-collection report, "Water-resources data, Texas, [Volume 4]" was compiled and published for water years 1991 and 1992. The annual data report for the San Antonio area has been prepared.

PLANS: Continue data collection, compilation, and reporting as needed. 


\section{PROPOSED REPORTS:}

Barbie, D.L., Kasmarek, M.C., Campodonico, Al, Approximate altitude of water levels in wells in the Chicot and Evangeline aquifers in the Houston area, Texas, 1991: U.S. Geological Survey OpenFile Report.

Approximate altitude of water levels in wells in the Chicot and Evangeline aquifers in the Houston area, Texas, 1992: U.S. Geological Survey Open-File Report.

Buckner, H.D., and Shelby, W.J., Index of surface-water stations in Texas, January 1991: U.S. Geological Survey Open-File Report.

Gabrysch, R.K., and Coplin, L.S., (interpretive), Land-surface subsidence, Fort Bend County, Texas: U.S. Geological Survey Open-File Report (Map).

Kasmarek, M.C., Development of ground-water resources in the Orange County area Texas and Louisiana, 1985-spring 1990: U.S. Geological Survey Water-Resources Investigations Report.

Kasmarek, M.C., Barbie, D.L., and Campodonico, Al, Approximate water-level changes in wells completed in the Chicot and Evangeline aquifers, 1977-93 and 1991-93, and measured compaction, 1973-92, in the Houston-Galveston region, Texas: U.S. Geological Survey OpenFile Report.

Locke, G.L., Approximate altitude of water levels in wells in the Chicot and Evangeline aquifers in Fort Bend County, Texas, 1991: U.S. Geological Survey Open-File Report.

Nalley, G.M., and Thomas, G.M., Compilation of hydrologic data or the Edwards aquifer, San Antonio area, Texas, 1991, with 1934-91 summary: U.S. Geological Survey Edwards Underground Water District Bulletin.

Ozuna, G.B., and Small, Ted, Hydrogeology of Lackland Air Force Base, San Antonio, Texas: U.S. Geological Survey Water-Resources Investigations Report.

Hydrogeology of Randolph Air Force Base, Texas: U.S. Geological Survey Water-Resources Investigations Report.

Ozuna, G.B., and Stein, W.G., Quality of the shallow ground water in southwest Bexar County, Texas: U.S. Geological Survey Water-Resources Investigations Report.

Santos, H.X., Approximate altitude of water levels in wells in the Chicot and Evangeline aquifers in Fort Bend County, Texas, 1992: U.S. Geological Survey Open-File Report. 
PROJECT TITLE: Water-Quality Stations

PROJECT NUMBER: TX 00-003

STUDY LOCATION: Statewide

COOPERATING

AGENCY: Multi-agency

PROJECT CHIEF: Frank C. Wells, District Office, Austin

PROJECT DURATION: Continuous since July 1937

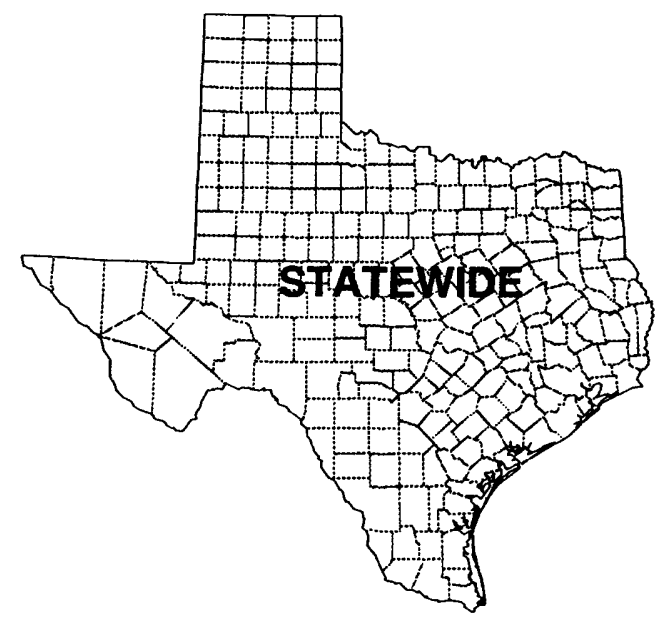

PROBLEM: The water-quality program includes collecting data for inventorying, assessing, and planning for the proper development, management, and utilization of the surface-water resources of the State. Rapid economic growth, population expansion, and increasing use of water for municipal, industrial, and agricultural purposes could cause the quality of the State's surface water to be degraded. Changes in atmospheric composition caused by increased use of fossil fuels may lead to the deposition of acid precipitation and alteration of the quality of runoff. Continuing development of areas around lakes and reservoirs may result in increases of nutrients, eutrophication, and related nuisance conditions. Thirty-four of the approximately 200 water-quality monitoring sites are part of the National StreamQuality Accounting Network, which is used to detect nationwide trends in water quality at key locations throughout the United States.

Water-quality samples are obtained from a network of observation wells to determine the chemical characteristics of ground water in the principal aquifers and to monitor the possible contamination of these aquifers from contaminated streamflow crossing the recharge areas. The adequacy of the continuing water-quality data program is reviewed annually and modified as necessary to provide a baseline of selected chemical, biological, and physical data required to satisfy national, State, and local needs.

OBJECTIVES: (1) To provide a national bank of water-quality data for broad Federal planning and action programs, and (2) to provide data for Federal management of interstate and international waters.

APPROACH: Operate a network of water-quality stations to provide average chemical concentrations, loads, and time trends as required by planning and management agencies.

PROGRESS: Continuous, daily, and periodic water-quality data were collected at the network of streams and reservoir sites in Texas as scheduled. The hydrologic data-collection report, "Water-resources data, Texas," was published in three volumes each for water years 1988, 1989, and 1990, and in four volumes for water year 1991. The ground-water data report, "Water-resources data, Texas, water year 1992, Volume 4," was published.

PLANS: Continue the collection and compilation of water-quality data for the existing network of stations. 


\section{PROPOSED REPORTS:}

Buckner, H.D., and Shelby, W.J., Index of surface-water stations in Texas, January 1991: U.S. Geological Survey Open-File Report.

Water resources data, Texas, water year 1992, Volume 1. Arkansas River Basin, Red River Basin, Sabine River Basin, Neches River Basin, Trinity River Basin, and intervening coastal basins: U.S. Geological Survey Water-Data Report for Texas.

Water resources data, Texas, water year 1992, Volume 2. San Jacinto River Basin, Brazos River Basin, San Bernard River Basin, and intervening coastal basins: U.S. Geological Survey WaterData Report for Texas.

Water resources data, Texas, water year 1992, Volume 3. Colorado River Basin, Lavaca River Basin, Nueces River Basin, Rio Grande Basin, and intervening coastal basins: U.S. Geological Survey Water-Data Report for Texas.

Rast, W.R., Donovan, G.A., and Slade, R.M., Jr., Water quality of Lake Travis, Texas: U.S. Geological Survey Water-Resources Investigations Report. 
PROJECT TITLE: Sediment Stations

PROJECT NUMBER: TX 00-004

STUDY LOCATION: Statewide

COOPERATING

AGENCIES: Lower Colorado River Authority; Texas Water

Development Board; University of Texas at Austin;

U.S. Bureau of Reclamation; U.S. Department of the Army, Corps of Engineers, Fort Worth, Texas, and Tulsa, Oklahoma

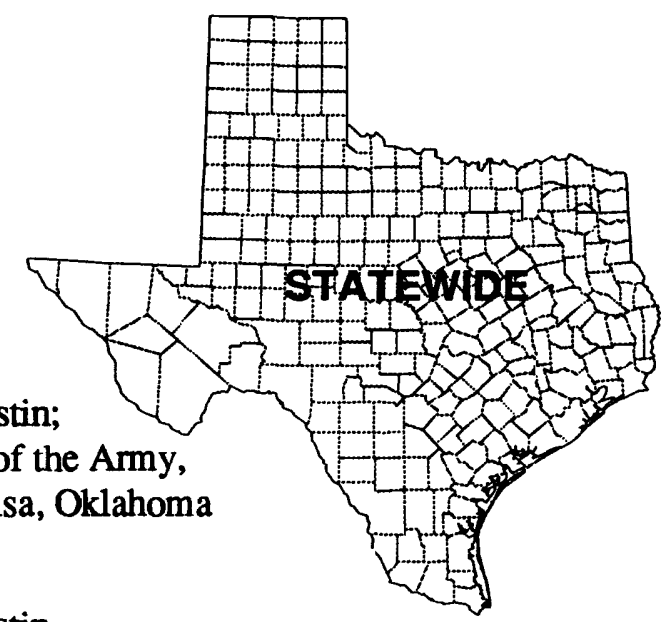

PROJECT CHIEF: Freeman L. Andrews, District Office, Austin

PROJECT DURATION: Continuous since November 1949

PROBLEM: Water-resource planning and water-quality assessment require a nationwide base level of relatively standardized information. Sediment concentrations and discharges in rivers and streams must be defined and monitored.

OBJECTIVES: (1) To provide a national bank of sediment data for use in broad Federal and State planning and action programs, and (2) to provide data for Federal management of interstate and international waters.

APPROACH: Data collected in the sediment data continuing program, involving other Federal agencies and local cooperators, are used for inventorying and defining sediment concentrations and discharges in rivers and streams. Rapid economic growth, population expansion, brush clearing, construction, and changes in land use could cause a change in the averages and trends in concentration, discharge, and particle size of sediment being transported by the rivers and streams. Sediment data are obtained from a network of about 41 stations, under varying flow conditions, to define particle-size distribution of suspended sediment and bed material. This continuing sediment-data program is reviewed annually and modified as necessary to provide a base for specific studies by Federal, State, and local agencies.

PROGRESS: Periodic sediment data were collected at the network of surface-water stations as scheduled. The report, "Water-resources data, Texas," was published in three volumes each for water years 1988, 1989, and 1990, and in four volumes for water year 1991. The ground-water data report, "Water-resources data, Texas, water year 1992, Volume 4," was published.

PLANS: Continue collection and compilation of sediment data for the existing network of stations.

\section{PROPOSED REPORTS:}

Buckner, H.D., and Shelby, W.J., Water resources data, Texas, water year 1992, Volume 1. Arkansas River Basin, Red River Basin, Sabine River Basin, Neches River Basin, Trinity River Basin, and intervening coastal basins: U.S. Geological Survey Water-Data Report for Texas.

Water resources data, Texas, water year 1992, Volume 2. San Jacinto River Basin, Brazos River Basin, San Bernard River Basin, and intervening coastal basins: U.S. Geological Survey WaterData Report for Texas.

Water resources data, Texas, water year 1992, Volume 3. Colorado River Basin, Lavaca River Basin, Nueces River Basin, Rio Grande Basin, and intervening coastal basins: U.S. Geological Survey Water-Data Report for Texas. 
PROJECT TITLE: National Trends Network for Monitoring Atmospheric Deposition

PROJECT NUMBER: TX 84-005

STUDY LOCATION: North-central and southeastern Texas

COOPERATING

AGENCY: None--U.S. Geological Survey funds only

PROJECT CHIEF: Frank C. Wells, District Office, Austin

PROJECT DURATION: Continuous since October 1983

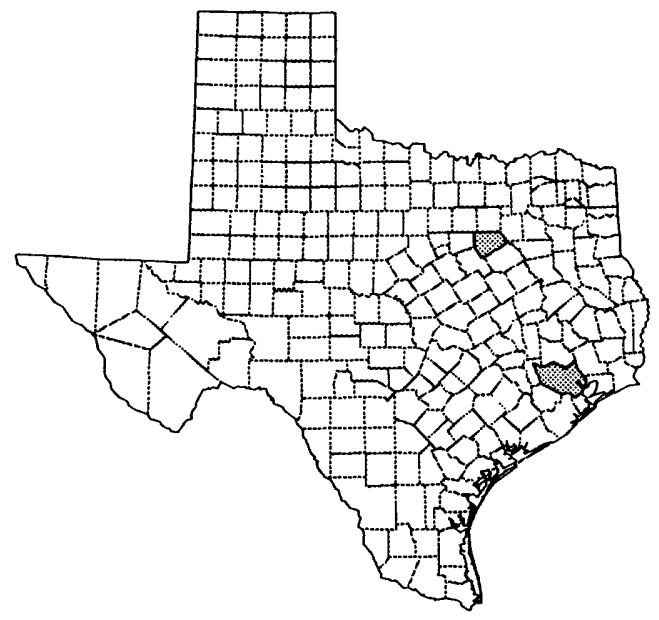

PROBLEM: The potential damage from acid rain is great. More knowledge of precipitation chemistry and resulting effects on the environment in the Nation are necessary to help avert future problems.

OBJECTIVES: (1) To determine variations in atmospheric deposition that occur on a week-to-week basis, and (2) to collect wet and dry deposition products for analysis of elements and compounds that can contribute to the chemical composition of surface waters.

APPROACH: (1) Set up monitoring stations as part of the National Trends Network; (2) maintain stations, make onsite measurements, process samples, and submit samples to an analytical laboratory; and (3) verify data retrievals and report on results.

PROGRESS: Data were collected on a weekly basis from one continuing station in the Fort Worth Subdistrict and one station in the Houston Subdistrict.

PLANS: Continue to collect data from the two sites and transmit samples of atmospheric deposition to the laboratory for analysis. Prepare reports at the regional and national levels. 
PROJECT TITLE: Water Use

PROJECT NUMBER: TX 78-007

STUDY LOCATION: Statewide

COOPERATING

AGENCIES: City of Houston; Edwards Underground Water

District; El Paso Public Service Board; Harris-

Galveston Coastal Subsidence District; San Antonio

Public Works Department; Texas Water Development Board

PROJECT CHIEF: Dee L. Lurry, District Office, Austin

PROJECT DURATION: Continuous since October 1977

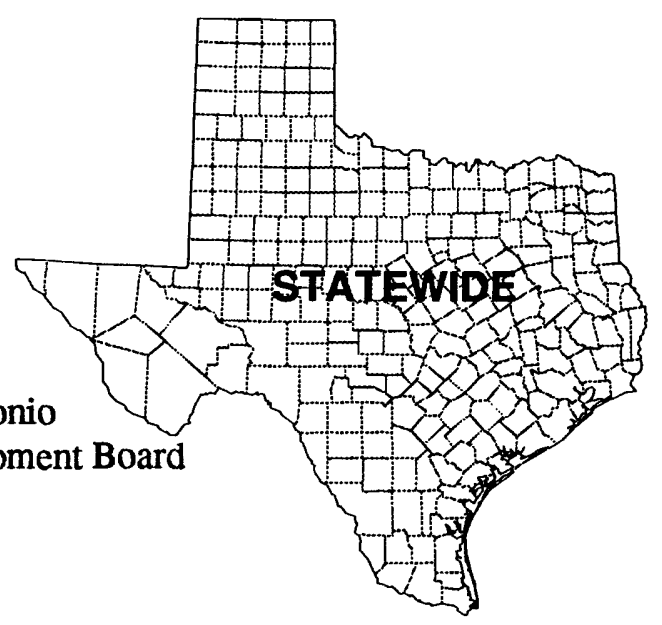

PROBLEM: Texas waters are undergoing increasing demands for domestic, industrial, agricultural, and other uses, and concerns for greater protection of water quality are increasing. Adequate information on uses of water, to complement that being collected to describe the quantity and quality of water, ultimately will aid decision makers in resolving many critical water problems such as resource allocation, environmental impact, energy development, and resource development.

OBJECTIVES: (1) To transfer water use from the Texas Water Development Board (TWDB) computerized data base to the U.S. Geological Survey (USGS) Aggregated Water-Use Data System (AWUDS), (2) to continue a program at the State level that collects and compiles water-use data and to develop and operate a State-level computer data-handling system to disseminate data to local users, and (3) to estimate 1990 water use for 13 categories for inclusion in a report on water use in the United States.

APPROACH: The project responsibilities are divided between the USGS and TWDB. Direction, management, and standards development to meet the national needs will be the responsibility of the USGS whereas the State needs will be the responsibility of the TWDB. The major operational responsibilities of the USGS include quality control review of the latest available data from TWDB and revision of data to conform to USGS water-use guidelines. Those guidelines include submission of 13 categories of water-use data by 254 counties, 1,044 eight-digit Hydrologic Unit codes, and 12 major aquifers to the AWUDS maintained by Reston. The major operational responsibility of the TWDB is to copy selected water-use data to computer tapes from existing TWDB files.

PROGRESS: The TWDB has continued the annual data-collection and compilation program for several categories of water use except irrigation. Water use for irrigation is determined every fifth year, with 1989 being the last year for estimation. Annually, the TWDB has prepared a computerized data tape for use by the USGS for entry into the USGS data base. Data for ground-water usage in Houston, San Antonio, and El Paso areas are being compiled. Water-use data for 1990 for 13 categories of use was compiled into aggregated software and submitted for publication by Reston Headquarters in a national water-use report.

PLANS: Publish data compiled for 1990 in a water-resources investigations report similar in format to a previous withdrawal report for 1985 . Propose to work on site-specific water-use information on a regional level.

\section{PROPOSED REPORT:}

Lurry, D.L., Estimated freshwater withdrawals in Texas, 1990: U.S. Geological Survey Water-Resources Investigations Report. 


\section{Hydrologic Investigative and Research Programs}

To accomplish the mission of conducting analytical and interpretive water-resources appraisals and basic problem-oriented research, the U.S. Geological Survey conducts the hydrologic investigative and research programs. These programs may concentrate on the ground-water, surface-water, or waterquality disciplines or integrate any combination of them. Specialized data-collection efforts often are part of the individual program. The areal extent for a study ranges from a county or smaller area to several States. These programs generally are 1 to 5 years in duration, but may last over 10 years if substantial data collection is required. Each program is concluded with one or more interpretive reports. Intermediate data reports often are published.

The investigative and research programs in Texas are described in the following pages. The summaries include projects that were funded or that were completed except report during any or all of the years 1989-92. Reports that have been published or approved for publication during 1989-92 are listed in a separate section at the end of this report. 
PROJECT TITLE: Urban Hydrology Study in the Houston Metropolitan Area

PROJECT NUMBER: TX 65-028

STUDY LOCATION: Southeastern Texas

COOPERATING

AGENCIES: City of Houston; Harris County Flood Control District; Texas Water Development Board; U.S. Department of the Army, Corps of Engineers, Galveston, Texas

PROJECT CHIEF: Fred Liscum, Subdistrict Office, Houston

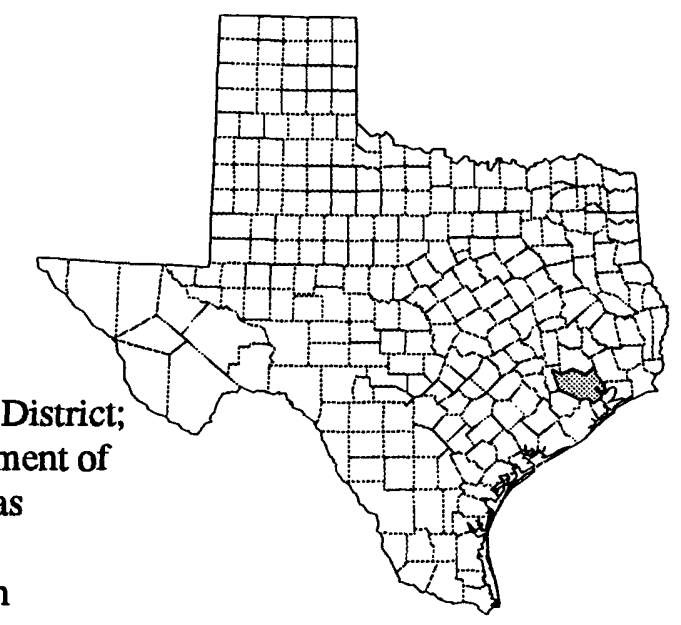

PROJECT DURATION: Continuous since July 1964

PROBLEM: The city of Houston experiences severe flood problems associated with storm-water runoff. The quality of water discharged from urbanized areas also is of concem. Few hydrologic data are available to make adequate decisions for controlling peak runoff or for establishing land-use practices to minimize the adverse impacts of runoff water quality on receiving streams.

OBJECTIVES: (1) To collect hydrologic data for studies to determine the effects of urbanization on flood discharge and total runoff with variations in rainfall patterns, rainfall intensity, and drainage areas; (2) to delineate actual floods in order to determine flood-hazard areas; (3) to provide water-quality data for selected areas of differing land use from water samples collected during runoff, which differ by season and magnitude; (4) to establish techniques for predicting flood frequencies in an urbanizing area; and (5) to determine the effects of urban development on storm runoff.

APPROACH: Drainage basins with different hydrologic characteristics will be instrumented to collect simultaneous rainfall-runoff data. Field surveys will be done to determine areas affected by unusual floods. Water-quality samples will be collected in selected areas to reflect the relations among water quality, land use, season, and flood magnitude. Regression analyses will be used to determine possible relations between flood-peak magnitude or flood-runoff volumes and drainage-basin characteristics. Mathematical models will be used to determine the effects of urbanization on the coastal area.

PROGRESS: Data has been finalized for a 25-year summary report. Finalization of data for a 5-year report is being processed as verified. Work on the "Effects of urban development" report has begun.

PLANS: Complete reports on (1) statistical summary and review of the hydrologic data, and (2) statistical analysis of the effects of urban development on storm runoff. Prepare a 5-year data report. The project has converted to continuous 5-year data reports and annual interim letter reports.

\section{PROPOSED REPORTS:}

Brown, D.W., and Paul, E.M., Houston urban 5-year report, 1990-95: U.S. Geological Survey Open-File Report.

Liscum, Fred, Effects of urbanization on flood peaks and volumes in the Houston, Texas area: U.S. Geological Survey Water-Resources Investigations Report.

Liscum, Fred, Brown, D.W., Locke, G.L., and Kasmarek, M.C., Statistical summary of hydrologic data for urban studies in the Houston metropolitan area, Texas, 1964-89: U.S. Geological Survey Open-File Report. 
PROJECT TITLE: West Gulf Coast Regional Aquifer-System Analysis (RASA)--Texas Aquifer Systems and Ground-Water Atlas of the United States--Chapter E: Texas and Oklahoma

PROJECT NUMBER: TX 82-075

STUDY LOCATION: Southeastern Texas

COOPERATING

AGENCY: None--U.S. Geological Survey funds only

PROJECT CHIEF: Paul D. Ryder, District Office, Austin

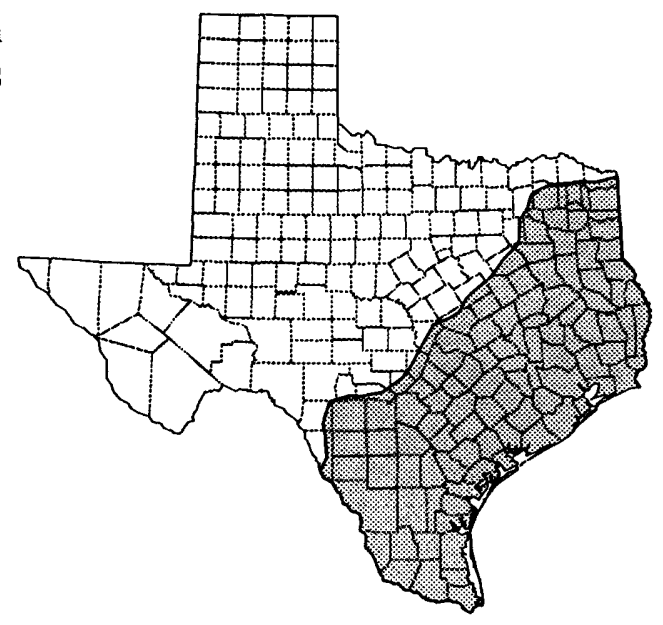

PROJECT DURATION: March 1982 to September 1992

PROBLEM: The Texas part of the West Gulf Coast (WGC) Regional Aquifer-System Analysis (RASA) has areas of large ground-water development that have problems associated with large decreases of aquifer heads, subsidence, and saltwater intrusion. Other areas in the Texas part have potential for additional development of ground water, but the effects of those increases are not known. The Water Resources Division has accumulated vast quantities of ground-water data over many years, and this information has been published in reports of local to regional scale. Planners, the lay public, consultants, governmental regulatory agencies, and congressional staffers routinely request information about aquifer locations and nationwide ground-water conditions. These inquiries often are not handled efficiently or adequately by our present resources. The Atlas contains a summary of the most important ground-water information that the U.S. Geological Survey has collected and published over many years.

OBJECTIVES: In support of the multistate WGC-RASA program, the Texas District will (1) contribute in the definition and determination of the interrelation of the major and minor aquifer systems of Tertiary and Quaternary ages, (2) participate in the development of a computerized data base, (3) correlate the continuity of aquifers with adjacent States, (4) develop and calibrate ground-water flow models, and (5) estimate future water needs for the purpose of estimating the aquifer's response to future withdrawals. Chapter E of the Atlas will (1) provide a summary for the Texas and Oklahoma part of the Nation's ground-water resources for an audience that includes Federal to local governmental agencies, congressional staffers, colleges and universities, planners and managers, consultants, and the lay public; and (2) synthesize ground-water information, that now exists at many different study scales, into a document that can be used to respond to requests from the above groups and others.

APPROACH: Viable aquifers and confining beds will be identified and delineated, and aquifer parameters and confining-bed characteristics will be identified. These will be used to develop digitalcomputer models that will be coordinated on a regional scale (intra-State) and used as tools in the overall planning and management of the area's ground-water resources. Existing interpretations will be synthesized, merged, and abutted as necessary. Specific maps and other products will be constructed as needed. The scale of the Atlas will permit only the important aquifers in Texas and Oklahoma to be illustrated and discussed. The latest interpretations and compilations made by RASA studies and national water summaries will be incorporated.

PROGRESS: Professional Paper 1416-E, entitled "Hydrology of the Texas Gulf Coast Aquifer Systems," by P.D. Ryder and A.F. Ardis, has received Director's approval, and is in the Publications Management Unit for further processing by the Geologic Division. The report also is available as Open- 
File Report 91-64. The report includes a quantitative description of the flow system resulting from the calibration of a 3-dimensional, 14-layer digital model. The hydrologic investigations atlas, "Groundwater atlas of the United States--Chapter E: Oklahoma and Texas," by P.D. Ryder, has been approved. A report by E.T. Baker, showing hydrostratigraphic strike and dip sections, representing 1,585 miles of the Coastal Plain of Texas, has received colleague review.

PLANS: Obtain Director's approval for report on hydrostratigraphic strike and dip sections.

\section{PROPOSED REPORT:}

Baker, E.T., Jr., Stratigraphic nomenclature and geologic sections of the Coastal Plain of Texas: U.S. Geological Survey Open-File Report. 
PROJECT TITLE: Solute-Transport Modeling of Ground Water in the Hueco Bolson, El Paso-Fort Bliss Area

PROJECT NUMBER: TX 83-080

STUDY LOCATION: Far West Texas and south-central New Mexico

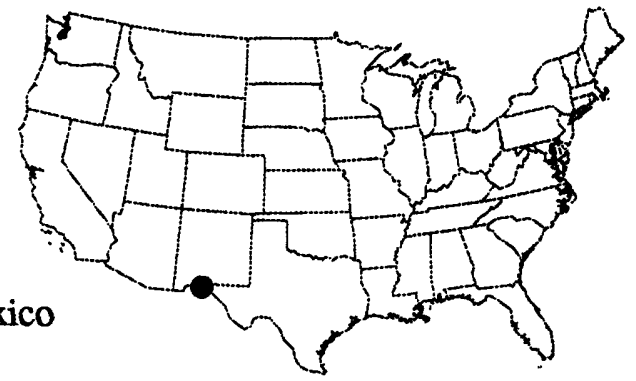

COOPERATING

AGENCIES: El Paso Public Service Board; Texas Water Development

Board; U.S. Department of the Army, Corps of Engineers, Fort Bliss, Texas

PROJECT CHIEF: George E. Groschen, Subdistrict Office, San Antonio

PROJECT DURATION: October 1982 to September 1986

PROBLEM: More than 10 million acre-feet of fresh ground water in the Hueco bolson is being depleted. The quality of the freshwater is threatened by the intrusion of saline water that almost surrounds the freshwater reservoir. Furthermore, there is interest in recharging the aquifer with treated wastewater. The potential for contamination resulting from continued and increased pumpage is unknown. The hydrologic relation between the saline water and the freshwater is poorly understood.

OBJECTIVES: (1) To define and quantify the hydrologic effects of historic and projected pumping through the use of a solute-transport ground-water flow model, (2) to use this model to determine the movement of saline water, and (3) to determine the model's reliability and parameter sensitivity and recommend procedures for improving its reliability and accuracy.

APPROACH: (1) Review previous studies to develop a conceptual model of the hydrologic system and to compile data, (2) set up the revised U.S. Geological Survey three-dimensional heat and solute transport model, (3) calibrate and test the mathematical model for reliability and accuracy, and (4) use the model to simulate pumping stress to predict salinity and water levels for selected water-withdrawal plans.

PROGRESS: Final revisions to the report were made. Report was sent to Region, approved, and forwarded to Reston for approval. The project is complete except for the report.

PLANS: Approve the report as water-supply paper and print it as open-file, pending publication of water-supply paper.

\section{PROPOSED REPORT:}

Groschen, G.E., Numerical-simulation analysis of the movement of saline water in the Hueco bolson aquifer, El Paso, Texas, and adjacent areas: U.S. Geological Survey Water-Supply Paper. 
PROJECT TITLE: Near-Real-Time Flood Routing along Cypress Creek, Harris County

PROJECT NUMBER: TX 83-082

STUDY LOCATION: Southeast Texas

COOPERATING

AGENCY: Harris County Flood Control District

PROJECT CHIEF: Fred Liscum, Subdistrict Office, Houston

PROJECT DURATION: January 1983 to September 1986

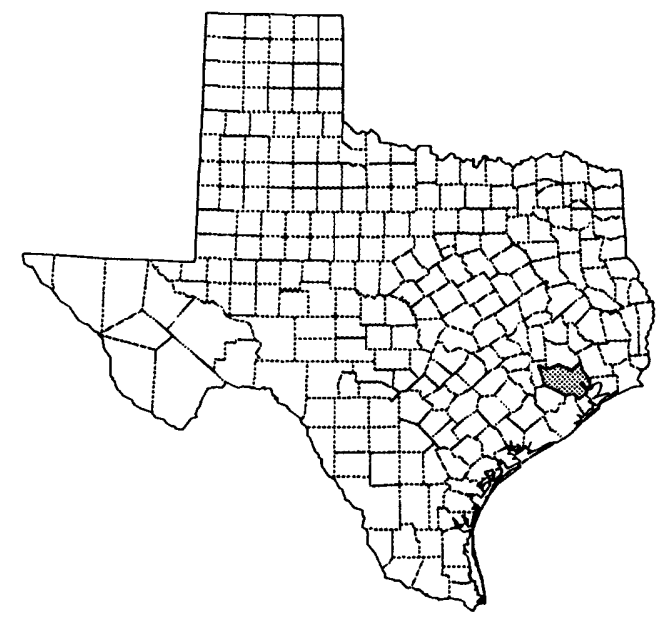

PROBLEM: Some of the most intense urban growth in the Houston metropolitan area is occurring in northern Harris County. Cypress Creek flows through this urbanized area before discharging into Lake Houston. Typical of southeast Texas, the area is relatively flat, and in urban areas, the channel has been rectified to improve conveyance. Because of the large extent of urbanization and its continued increase, flood-warning methods are needed to aid local agencies in warning residents of impending flooding.

OBJECTIVE: To develop a procedure for routing floods using near-real-time hydrologic data in the lower reach of Cypress Creek.

APPROACH: The selected modeling approach includes the use of a distributed hydrologic-based watershed model and a hydraulic-based streamflow routing model. The storm-rainfall-driven watershed model will be applied independently in the upper and lower parts of the basin to generate inflow data needed by the routing model. The routing model will predict the magnitude and timing of the flood wave at selected points along the streams. Near-real-time storm-rainfall data will be used in the watershed model to generate inflow to the routing model.

PROGRESS: Model results are complete. The project is complete. No reports are planned. 
PROJECT TITLE: Potential Impact of Diversions of the Trinity

River on the Water Quality of Lake Houston, Texas--Phase I, Prediversions

PROJECT NUMBER: TX 84-083

STUDY LOCATION: Northeast Houston

COOPERATING

AGENCY: City of Houston

PROJECT CHIEF: Fred Liscum, Subdistrict Office, Houston

PROJECT DURATION: Continuous since October 1983

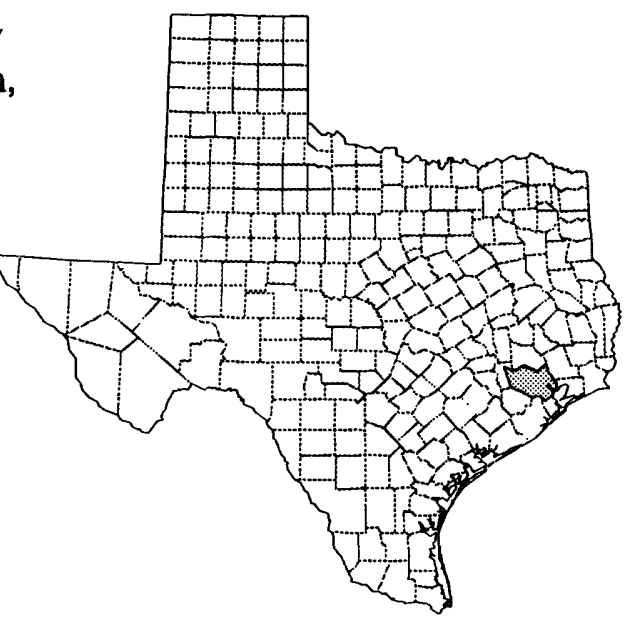

PROBLEM: Rapid growth in the Houston metropolitan area is resulting in increased demand for industrial and municipal water supplies. Because of problems associated with ground-water development and the limitation of resources, additional surface water must be made available to ensure an adequate supply. Current plans for providing additional water include diversions of surface water from the Trinity River, through Luce Bayou, into Lake Houston. Diversion of nutrient-laden water from the Trinity River may adversely affect the quality of water in Lake Houston.

OBJECTIVES: (1) To define the areal and temporal variations in water quality and stratification patterns in Lake Houston under current conditions, (2) to define the areal and temporal variations in water quality of inflows to Lake Houston from streams in the San Jacinto River Basin, (3) to relate the water quality of inflows to the water quality in Lake Houston, (4) to define the temporal variations in the quality of water available for diversion from the lower Trinity River, and (5) to predict the potential impact of diversions from the Trinity River on the water quality of Lake Houston.

APPROACH: The study is designed to (1) measure the quantity and quality of the natural inflow into Lake Houston from major streams; (2) collect comparable data on the Trinity River, near the point of diversion; and (3) determine the seasonal and areal variations of the chemical, physical, and biological characteristics of the water in Lake Houston. The periodic analysis and interpretation of the data will relate the response of the water quality in Lake Houston to its natural inflows using multiple regression techniques and its predicted response to mixing natural inflows with diversion of Trinity River water using a dynamic lake model.

PROGRESS: Data report tables are finalized. Model has been adapted and calibration runs have begun.

PLANS: Publish data report to summarize data collected from August 1983 through September 1989.

\section{PROPOSED REPORTS:}

Goss, R.L., and Liscum, Fred, Hydrologic data for Lake Houston near Houston, Texas, 1983-90: U.S. Geological Survey Water-Resources Investigations Report.

Liscum, Fred, and Rast, W.R., The water-quality impacts of interbasin transfer of water to Lake Houston, Texas: U.S. Geological Survey Water-Resources Investigations Report. 
PROJECT TITLE: Sources and Inflow of Nutrients into Lake Lewisville

PROJECT NUMBER: TX 84-084

STUDY LOCATION: Northeast Texas

COOPERATING

AGENCY: Dallas Water Utilities Department

PROJECT CHIEF: Scott Gain, Subdistrict Office, Fort Worth

PROJECT DURATION: October 1983 to September 1988

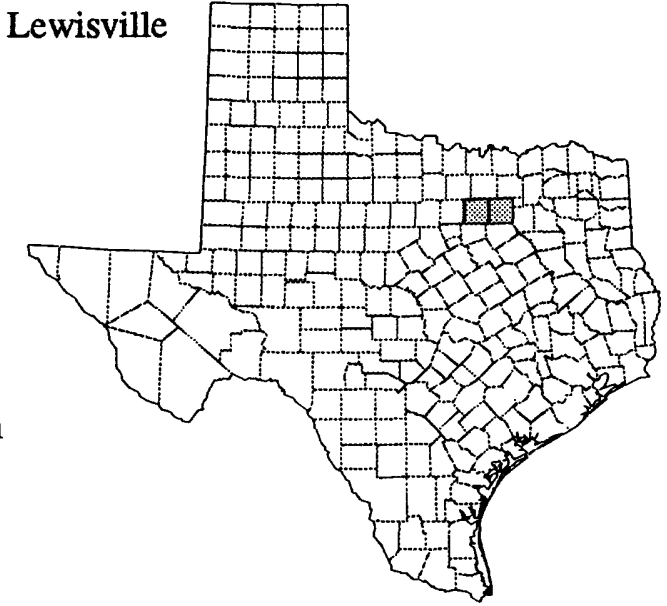

PROBLEM: Lake Lewisville is located on the northern fringes of the rapidly growing Dallas-Fort Worth metropolitan area and is a major source of water for Dallas. During summers, algal blooms in the lake often result in taste and odor problems and consequently increase the cost of water treatment for the city. Before appropriate actions can be taken for the management of the lake's water quality, the source of nutrient loading must be identified and evaluated in terms of magnitude of input, effect on lake nutrient dynamics, and management feasibility.

OBJECTIVES: (1) To evaluate potential nitrogen, phosphorus, and organic carbon loading by streams tributary to Lake Lewisville; (2) to identify the streams having the most nutrients; (3) to determine annual loads of nitrogen and phosphorus from three of those streams; and (4) to evaluate the relative importance of point and nonpoint sources to loads of nitrogen and phosphorus contributed to the lake.

APPROACH: The study includes the collection of two unique data sets. The first is the results of field and lab analyses on samples collected in each of two synoptic surveys--one survey at low flow and one at high flow. During synoptic surveys, samples were collected and discharges were measured at 30 sites on streams within the drainage basin of Lake Lewisville. The synoptic sampling data, along with other data previously published for major streams in the basin, were intended to meet the first two objectives.

The second data set includes the results of more comprehensive sampling at three sites that have the potential to affect the quality of water in the lake. Runoff data from four storms at these sites will be used to calculate annual loads to the lake. These data, in addition to reported loads by wastewater treatment plants discharging into Lake Lewisville, will be used to meet the third and fourth objectives of the study.

PROGRESS: The project is complete except for the report.

\section{PROPOSED REPORT:}

Gain, W.S., Nitrogen and phosphorus loading of Lewisville Lake, north-central Texas, 1984 to 1987: U.S. Geological Survey Open-File Report. 
PROJECT TITLE: Edwards-Trinity Regional Aquifer-System Analysis (RASA)

PROJECT NUMBER: TX 85-090

STUDY LOCATION: Central and northeast Texas, southeast Oklahoma, and southwest Arkansas

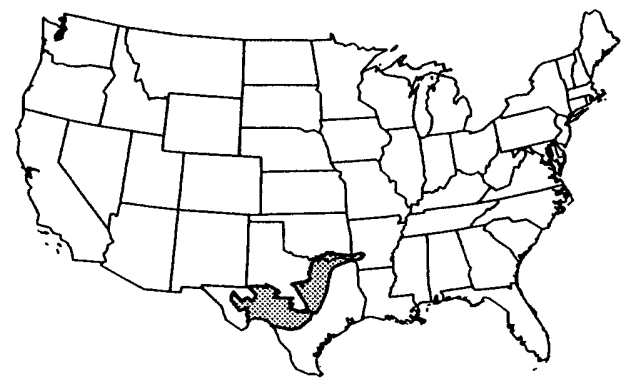

COOPERATING

AGENCY: None--U.S. Geological Survey funds only

PROJECT CHIEF: Peter W. Bush, District Office, Austin

PROJECT DURATION: January 1986 to September 1993

PROBLEM: Continued use of water from aquifers of the Cretaceous age in the study area has the potential to lower water levels, decrease streamflows, and cause deterioration of water quality. Lower water levels in aquifers could decrease springflow and aquifer discharge to streams in discharge areas, and could increase aquifer recharge from streams in recharge areas. In some areas, moderately saline water occurs in aquifers or zones of aquifers adjacent to pumping centers. Continued pumping creates a potential for contamination of the water supply.

OBJECTIVE: (1) To better understand the long-term water-yielding potential of the aquifers that compose the Edwards-Trinity regional aquifer system, and (2) to provide regional descriptions of the hydrogeologic framework, the water chemistry, and the ground-water flow system.

APPROACH: A multidisciplinary approach will be used. Geologists will construct a hydrogeologic framework that divides the aquifer system into regional aquifers and confining units on the basis of permeability. Ground-water modelers will use the hydrogeologic framework to construct digital flow models on regional scales. Geochemists will describe the water chemistry and interpret the flow system based on the water chemistry. Different interpretations or hypotheses of the structure of the aquifer system and patterns of flow suggested by geologic, hydrologic, and geochemical studies will be tested with the digital models.

PROGRESS: In the waning stages of a RASA project, the emphasis of work is on reports. Five reports have been published--three reports in post-approval processing, four reports in review, three proposed reports, and two reports in the planning stage. The most comprehensive report to date (in review) is a hydrologic overview of the aquifer system that will serve as the foundation for the hydrogeologic framework professional paper, which is proposed. A report documenting application of a regional singlelayer steady-state finite-element model is in review. Calibration of a multilayer, transient finite-element model of the Hill Country-Balcones fault zone area is progressing. Interpretation of analyses of samples collected in the Hill Country has begun. Proposed hydrogeologic sections in the northern study area are in progress.

PLANS: Complete a draft of the hydrogeologic framework professional paper. Complete calibration of the multilayer, transient Hill Country-Balcones fault zone model. Document interpretations of Hill Country sampling in a report. Complete hydrogeologic sections in the northern project area. Complete drafts of proposed reports, and continue to guide reports in review through the process. 


\section{PROPOSED REPORTS:}

Baker, E.T., Jr., Hydrogeologic sections of the Edwards-Trinity aquifer and its confining units, northcentral Texas, southeast Oklahoma, and southwest Arkansas: U.S. Geological Survey Geophysical Investigations Maps.

Barker, R.A., and Ardis, A.F., Hydrogeologic framework of the Edwards-Trinity aquifer system, westcentral Texas: U.S. Geological Survey Professional Paper.

Barker, R.A., Bush, P.W., and Baker, E.T., Jr., Hydrogeologic overview of the Edwards-Trinity aquifer system, west-central Texas: U.S. Geological Survey Water-Resources Investigations Report.

Bush, P.W., Dissolved solids, concentrations, and hydrochemical facies in water of the Edwards-Trinity aquifer system, west-central Texas: U.S. Geological Survey Water-Resources Investigations Report.

Bush, P.W., and Barker, R.A., Summary of the hydrology of the Edwards-Trinity aquifer system, westcentral Texas: U.S. Geological Survey Professional Paper.

Kuniansky, E.L., Ground-water flow in the Edwards-Trinity aquifer system, west-central Texas: U.S. Geological Survey Professional Paper.

Kuniansky, E.L., and Holligan, K.Q., Simulations of flow in the Edwards-Trinity aquifer system and contiguous hydraulically connected units, west-central Texas: U.S. Geological Survey WaterResources Investigations Report.

Lee, R.W., Geochemical characterization of ground water in the Trinity aquifer of the Hill Country, westcentral Texas: U.S. Geological Survey Water-Resources Investigations Report.

Lurry, D.L., Withdrawals from the Edwards-Trinity aquifer system and contiguous hydraulically connected units, west-central Texas, 1989-90: U.S. Geological Survey Water-Resources Investigations Report.

Wynn, K.H., Potentiometric surface the Edwards-Trinity aquifer system and contiguous hydraulically connected units, west-central Texas, 1988-90: U.S. Geological Survey Water-Resources Investigations Report. 
PROJECT TITLE: Hydrologic Controls Affecting Ground-Water Movement in the Vicinity of the Freshwater/ Saline-Water Interface in the Edwards Aquifer, San Antonio Region

PROJECT NUMBER: TX 85-094

STUDY LOCATION: South-central Texas

COOPERATING

AGENCIES: Edwards Underground Water District, San Antonio Water Board

PROJECT CHIEF: George E. Groschen, Subdistrict Office, San Antonio

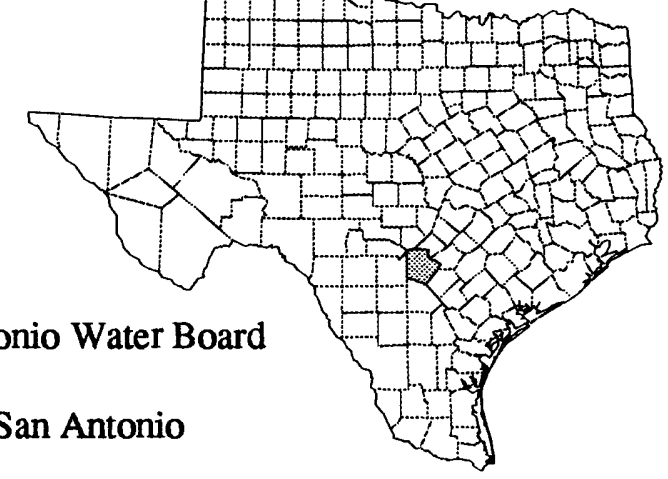

PROJECT DURATION: October 1984 to September 1986

PROBLEM: The Edwards aquifer in the vicinity of San Antonio is a very productive and highly utilized freshwater confined carbonate aquifer. The freshwater zone of the aquifer is bordered by the saline zone that extends downdip from the freshwater body. The line of separation between these two zones is locally called "the bad-water line." The intent of the study is to obtain hydrogeologic and hydrochemical data that will be used to develop a hypothesis on the hydrologic controls affecting the flux in this part of the aquifer.

OBJECTIVES: (1) To delineate the three-dimensional shape of the interface between the freshwater and saline water, (2) to obtain data on the vertical and horizontal circulation in the vicinity of the "bad-water line," and (3) to establish permanent monitoring wells to determine transient changes in water quality.

APPROACH: A test drilling program is designed whereby three different clusters of wells are drilled in the aquifer. A well cluster is located in the freshwater zone, in the transient zone between the fresh and saline zones, and in the saline zone. Extensive testing of formation was conducted at each cluster. Tests include vertical flow tests and aquifer yield tests. Geophysical logging provided porosity, lithology, and water-quality tools to determine vertical and lateral variations.

PROGRESS: An extra colleague review was done, and the author responded to it. The project is complete except for the report.

PLANS: Review, process, and publish report.

\section{PROPOSED REPORT:}

Groschen, G.E., Analysis of data from test sites along the freshwater/saline-water interface of the Edwards aquifer, San Antonio, Texas: U.S. Geological Survey Open-File Report, pending Water-Supply Paper. 
PROJECT TITLE: Effects of Ground-Water Development in Fort Bend County

PROJECT NUMBER: TX 86-095

STUDY LOCATION: East-central Texas

COOPERATING

AGENCY: Fort Bend County

PROJECT CHIEF: Glenn L. Locke, Subdistrict Office, Houston

PROJECT DURATION: October 1985 to September 1987

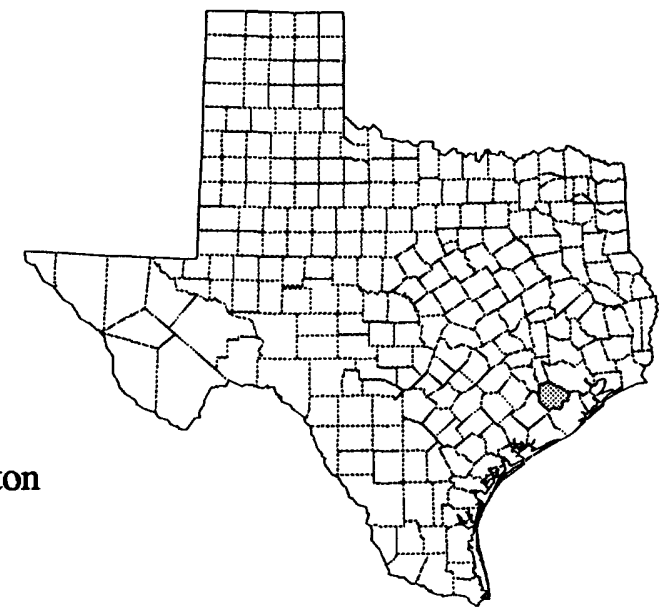

PROBLEM: Fort Bend County is one of the fastest growing counties in the United States and is dependent entirely on ground water for supply. An investigation of the ground-water resources of Fort Bend County was done by the U.S. Geological Survey in 1968-69. Since 1969, the increased development in Fort Bend County and the growth of the city of Houston has caused increased production of ground water. Fort Bend County has been impacted by declines in water levels, land-surface subsidence, and possibly, encroachment of saltwater from salt domes and by updip migration. Although the city' of Houston has only one water well in Fort Bend County, declines in water levels in Fort Bend County as a result of pumpage in adjacent Harris County have been significant. Two large well fields ( 25 to 30 million gallons per day) in Fort Bend County have been planned by the city of Houston, which is causing concern to Fort Bend County officials. Information on the current and potential impact of development is needed for planning purposes, which may include the creation of a subsidence control district.

OBJECTIVES: (1) To update information collected in 1968-69, (2) to determine the impact of recent development of ground water in Fort Bend County and the western part of Harris County, and (3) to delineate the areas most susceptible to land-surface subsidence.

APPROACH: Well inventory, pumpage inventory, and water-level measurement networks will be updated and expanded as necessary to provide adequate control in critical areas. A limited program of sampling wells in areas near salt domes, particularly the Blue Ridge Dome, will be instituted to monitor any salinity changes. Maps of water-level altitudes and changes since the county report (1969) will be made. Available data on land-surface subsidence will be collected. Areas most susceptible to landsurface subsidence, based on clay thickness (determined in this study) and compressibility (from studies in adjacent areas), will be described.

PLANS: The project is complete and the report is published. 
PROJECT TITLE: Ground-Water Contribution of Salinity in the Upper Colorado River

PROJECT NUMBER: TX 86-096

STUDY LOCATION: Northwest Texas

\section{COOPERATING}

AGENCY: Colorado River Municipal Water District

PROJECT CHIEF: Raymond M. Slade, Jr., District Office, Austin

PROJECT DURATION: October 1985 to September 1989

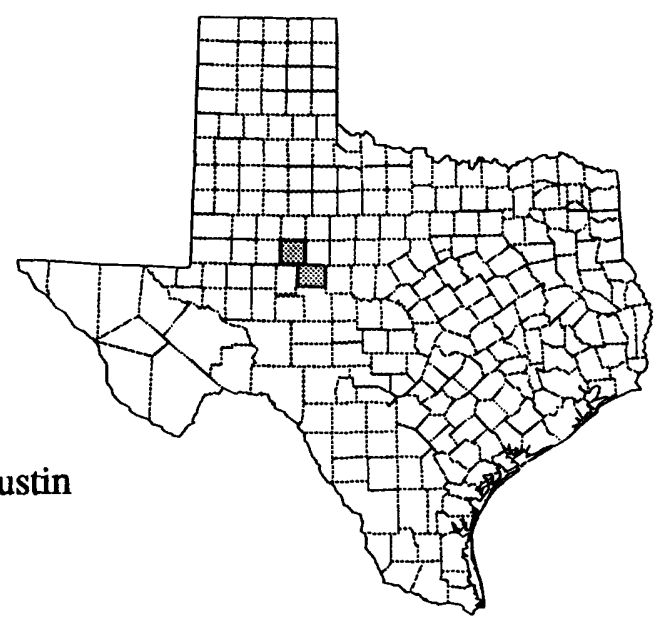

PROBLEM: Trends showing increasing concentrations of dissolved solids are occurring in a 40-mile reach of the Colorado River upstream from E.V. Spence Reservoir. From October 1972 to September 1982, the flow-adjusted concentration of dissolved solids in the Colorado River at Colorado City increased at an average rate of more than 270 milligrams per liter per year. Similarly, the flow-adjusted concentration of dissolved solids in streamflow at Beals Creek near Westbrook increased at an average rate of more than 270 milligrams per liter per year. Several studies indicate that ground water contributes significantly to the salinity of the Colorado River upstream from E.V. Spence Reservoir. However, the trends of increasing salinity in surface waters after 1972 is strong evidence that the inflow of saline ground water between Colorado City and the E.V. Spence Reservoir has resulted from causes other than the natural discharge of shallow ground water.

OBJECTIVES: (1) To delineate the source areas of saline ground-water inflow and determine the quality and quantity of ground water to the study reaches, (2) to identify and describe the aquifers that contribute water to the streams, (3) to determine the historical ground-water conditions in the aquifer, (4) to determine the current ground-water conditions, (5) to locate and describe oil-field activities, and (6) to investigate the feasibility of using indirect techniques to identify specific sites of saline-water discharge.

APPROACH: (1) Conduct several base-flow reconnaissances of the quantity and quality of streamflow in the upper Colorado River and lower reaches of Beals Creek, Elm Creek, and the Concho River; (2) map the thickness and extent of aquifers that crop out or underlie the study area; (3) conduct a literature search; retrieve (from computer storage) water-level, water-quality, and related data in the study area, and tabulate and analyze such data to detect any changes or trends; (4) locate and inventory selected water wells and springs; (5) collect about 50 water samples from the inventoried wells and analyze the water for major inorganic chemical constituents; (6) locate and map all wells drilled in the area; (7) tabulate the quantity of salt water disposed, and indicate the methods of disposal; (8) tabulate data on secondaryrecovery operations; and (9) test indirect methods of locating saline-water seeps.

PROGRESS: The report was written and reviewed. Technical reviews were done by a District employee and two non-District employees. The project is complete except for the report.

\section{PROPOSED REPORT:}

Slade, R.M., Jr., and Buszka, P.M., Characteristics of streams and aquifers and causes and sources of salinity in the Upper Colorado River Basin, Texas: U.S. Geological Survey Water-Resources Investigations Report. 
PROJECT TITLE: National Lake Summary

PROJECT NUMBER: TX 86-097

STUDY LOCATION: Statewide

COOPERATING

AGENCY: None--U.S. Geological Survey funds only

PROJECT CHIEF: Walter R. Rast, District Office, Austin

PROJECT DURATION: October 1985 to September 1990

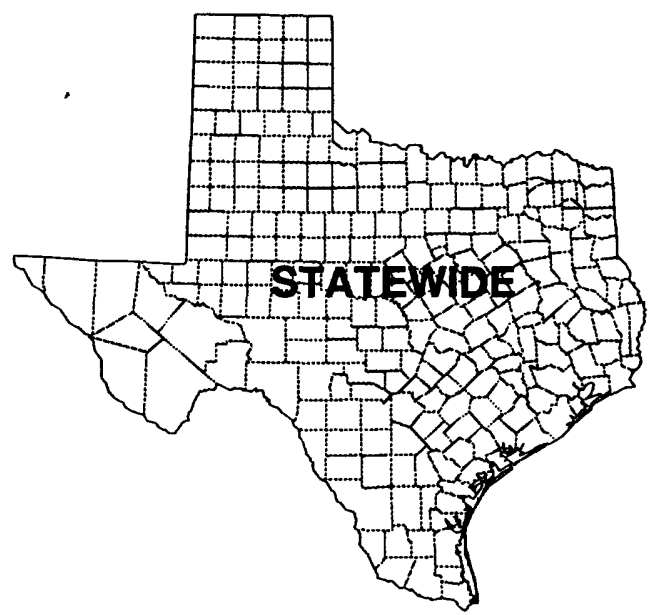

PROBLEM: Deterioration of water quality in receiving lakes and reservoirs is an inevitable consequence of human settlement in a drainage basin. Furthermore, problems of surface-water-quality deterioration will increase in importance in the United States as the extent of ground-water-quality deterioration becomes more widespread and as finite water resources are stressed with future population and economic growth. In order for scientifically sound management of the Nation's water resources to be achieved, we need to provide accurate lake and reservoir information and data for officials and agencies responsible for policy formulation.

OBJECTIVES: (1) To identify and compile relevant water-related information and data bases descriptive of the overall water quality of the Nation's lakes and reservoirs, and (2) to use the data bases to prepare a summary of the water quality of the Nation's lakes and reservoirs, especially conditions descriptive of the deterioration of water quality.

APPROACH: (1) Identify and compile water-quality data from existing data bases and written reports from Federal, State, and local studies; (2) determine the adequacy of such information for providing an assessment of the water quality of the Nation's lakes and reservoirs; and (3) using appropriate statistical and graphic techniques, prepare an assessment of the overall water quality of the Nation's lakes and reservoirs.

PLANS: The project is complete. 
PROJECT TITLE: Limestone Hydrology of the Edwards Aquifer, San Antonio Area

PROJECT NUMBER: TX 86-098

STUDY LOCATION: South-central Texas

COOPERATING

AGENCY: San Antonio Water Board

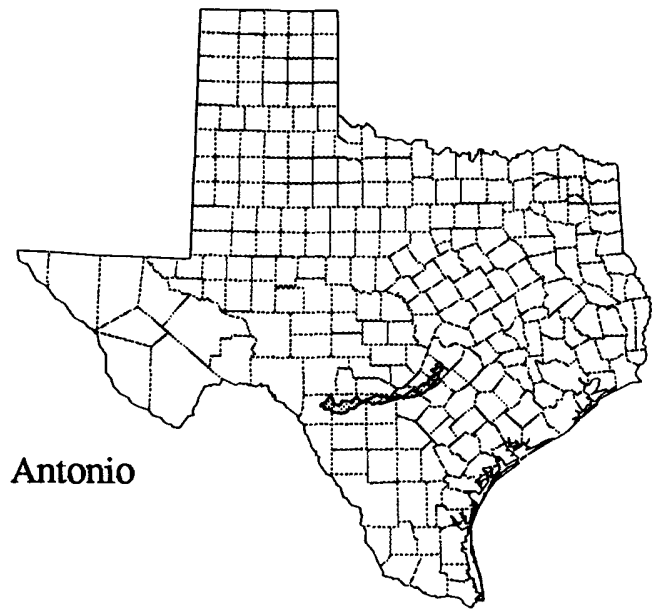

PROJECT DURATION: March 1986 to September 1986

PROBLEM: The Edwards aquifer is one of the most important limestone aquifers in the United States. It is a highly permeable and productive aquifer that has been designated the sole source of water supply for San Antonio and other towns in south-central Texas. The area demands for water are increasing rapidly, and this growth is projected to accelerate dramatically as the corridor between San Antonio and Austin undergoes expected population, agricultural, and industrial expansion. For the past 80 years, the U.S. Geological Survey has collected, analyzed, and published a great deal of information concerning the Edwards aquifer and the streams which recharge the aquifer. A consolidation of previously published U.S. Geological Survey reports will be prepared and become available to a large and diverse audience concerned with understanding the Edwards aquifer.

OBJECTIVE: To prepare a single document that integrates current knowledge of, with intuition concerning, scientific flow and storage within the Edwards aquifer in the San Antonio area. The report will serve as a source and guide of the geology and hydrology of the Edwards aquifer. The intended audience of the report primarily will be the practitioner in the field of water resources and the technical reader. The report will be prepared as a water-supply paper.

APPROACH: All previously published reports and data and the current understanding of the hydrogeologic characteristics of the Edwards aquifer will be used in this project.

PROGRESS: Review comments were incorporated into the report. The report is in the Publications Section. The project is complete except for the report.

PLANS: Process and publish the report.

PROPOSED REPORT:

Maclay, R.W., Geology and hydrology of the Edwards aquifer and the San Antonio area, Texas: U.S. Geological Survey Open-File Report pending Water-Supply Paper. 
PROJECT TITLE: Geohydrology of the Water Resources of Oak Spring, Big Bend National Park

PROJECT NUMBER: TX 86-101

STUDY LOCATION: West Texas

COOPERATING

AGENCY: National Park Service, Central Region

PROJECT CHIEF: Emest T. Baker, Jr., District Office, Austin

PROJECT DURATION: June 1986 to September 1989

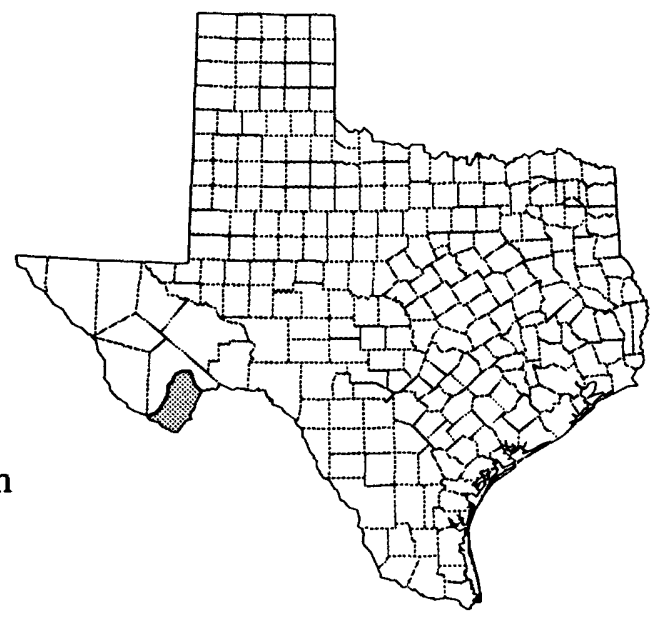

PROBLEM: Oak Spring is the sole source of water for a major developed area in Big Bend National Park. There is concern that water may migrate from sewage lagoons to the aquifer that supplies Oak Spring and contaminate the spring. There is also concern regarding the ability of Oak Spring to continue to provide sufficient quantities of water for the developed area.

OBJECTIVES: (1) To describe the hydrology of the aquifer supplying Oak Spring, (2) to determine the source of water supplying the spring and determine if the source includes the sewage lagoons, (3) to determine the quality of water in the aquifer, (4) to determine the direction and rate of ground-water movement, (5) to determine the changes in water quality in the aquifer between the lagoons and the spring, and (6) to determine the factors that affect the quantity and quality of water from the spring.

APPROACH: (1) Map the surface geology related to Oak Spring, (2) study the subsurface geologic features controlling water movement using test drilling and geophysical surveys (borehole and surface). Test holes will define hydraulic properties of the aquifer and serve to monitor water quality, and (3) collect water samples from springs, test wells, lagoons, and other sources, and analyze samples for a wide range of constituents and properties. Compare the results with historical data. Recorders will be installed in Oak Spring.

PROGRESS: The report has been written and is in Reston Headquarters awaiting approval. The project is complete except for the report.

PLANS: Respond to review comments; publish and distribute report.

\section{PROPOSED REPORT:}

Baker, E.T., Jr., Buszka, P.M., and Woodward, D.G., Hydrogeology and geochemistry of water of the Basin and Oak Spring areas of the Chisos Mountains, Big Bend National Park, Texas: U.S. Geological Survey Water-Resources Investigations Report. 
PROJECT TITLE: Kelly Air Force Base Installation Restoration Program, Phase II, Stage 3

PROJECT NUMBER: TX 87-102

STUDY LOCATION: Southwest Texas

COOPERATING

AGENCY: U.S. Department of the Air Force, Occupational and Environmental Health Laboratory

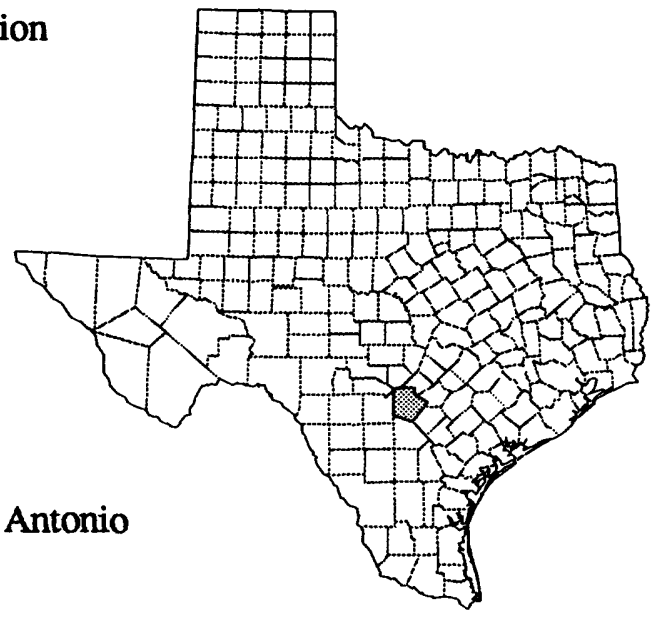

PROJECT DURATION: October 1986 to September 1988

PROBLEM: The Installation Restoration Program (IRP) of the Department of Defense (DOD) is a comprehensive program that identifies hazardous waste sites and evaluates the risks they pose to public health and to the environment on active, inactive, or formerly used DOD property.

OBJECTIVES: (1) To confirm the presence or absence of contamination within two specific sites of investigation, (2) to determine the extent and degree of contamination and the potential for migration of those contaminants, (3) to identify public health and environment hazards resulting from migrating pollutants, and (4) to delineate additional investigations that might be required.

APPROACH: (1) Review the Air Force IRP Phase I report; (2) drill about 50 shallow wells for sampling water, (3) collect and analyze soil cuttings, (4) collect samples for water-quality analyses from each well and emphasize volatiles and other pollutants, (5) estimate the magnitude, extent, and direction in which detected contaminants are moving, and (6) recommend actions following the study.

Water quality, soil quality, and hydrogeologic data will be analyzed and interpreted to estimate the magnitude and extent of contaminants and the direction in which those contaminants are moving. The data also will be used to identify potential environmental consequences of discovered contamination, based upon Federal and State standards.

PLANS: The project is complete except for the report.

\section{PROPOSED REPORT:}

Ozuna, G.B., Buszka, P.M., and Nalley, G.M., Ground-water contamination at two sites on Kelly Air Force Base, Texas: U,S. Geological Survey Water-Resources Investigations Report. 
PROJECT TITLE: Trends in Water-Quality Data in Texas

PROJECT NUMBER: TX 87-103

STUDY LOCATION: Statewide

COOPERATING

AGENCY: None--U.S. Geological Survey funds only

PROJECT CHIEF: Terry L. Schertz, Branch of Quality Assurance, Golden, Colorado

PROJECT DURATION: October 1986 to September 1991

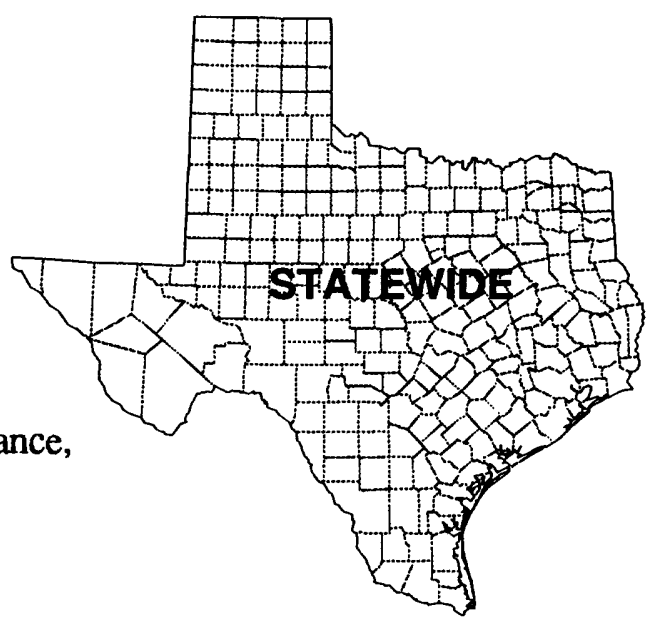

PROBLEM: The Texas District has a relatively long-term (1968 to present) water-quality data base for more than 150 streamflow-gaging stations located throughout the State. Examination of these data will provide valuable information on the changes in water quality under a wide variety of hydrologic conditions. The extent of spatial and temporal trends will enable water-planning, management, and regulating agencies to determine if water-quality management practices have had a substantial impact on improving water-quality conditions in the State.

OBJECTIVES: (1) To select sites from the Texas water-quality data base that have the appropriate characteristics necessary for trend detection, (2) to develop the methods needed to process extensive data sets with complicated patterns of variability and produce temporal trend results, and (3) to examine temporal trend results for evidence of regional patterns. A second phase to the project will incorporate sources of ancillary information and more detailed analysis of the flow and concentration data to establish possible causes of the trends detected in the first phase. The procedures developed and tested in this project are intended to serve as a prototype for future studies of large water-quality networks.

APPROACH: Data analysis will be done for the selected sites using a combination of subjective decisions and automated procedures designed to handle trend detection in large, complex data sets. The chemical parameters to be examined for detectable trends will include inorganic, trace element, nutrient, and pesticide constituents. Physical parameters such as water temperature, $\mathrm{pH}$, dissolved oxygen, specific conductance and biological oxygen demand also will be examined. The regional patterns of detectable trends in each constituent will be examined in more detail for possible sources in the second phase. Correlation between the trends and related ancillary data will be used to determine the most probable causes of the trends.

PROGRESS: The final report on the analysis and interpretation of trends in water-quality data in Texas is scheduled for completion by July 1992. The project is complete except for the report; the first draft is complete. The text was submitted for colleague review in July 1992.

PLANS: Complete the project.

\section{PROPOSED REPORT:}

Schertz, T.L., Wells, F.C., and Ohe, D.J., Sources of trends in water-quality data in Texas: U.S. Geological Survey Water-Resources Investigations Report. 
PROJECT TITLE: Water Surface and Flow Pattern of a Major Flood at the Texas Highway 43 Crossing of the Sabine River

PROJECT NUMBER: TX 87-104

STUDY LOCATION: Northeast Texas

COOPERATING

AGENCY: Texas Department of Transportation

PROJECT CHIEF: Dennis R. Myers, Subdistrict Office, Fort Worth

PROJECT DURATION: January 1987 to September 1988

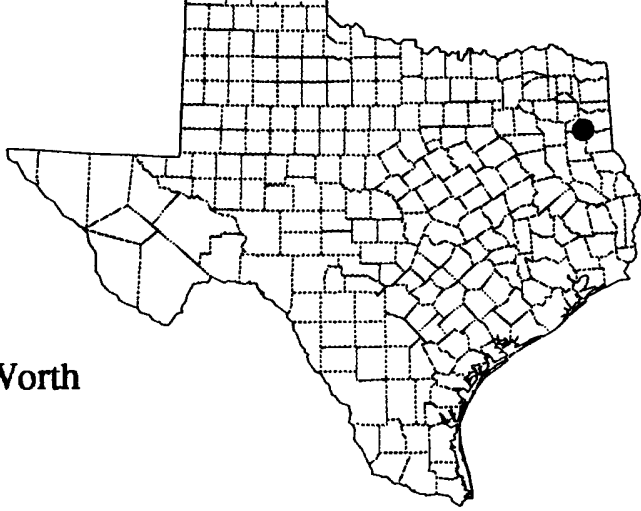

PROBLEM: Texas Highway 43 is overtopped by 10 -year recurrence interval floods on the Sabine River. The Texas Department of Transportation plans to raise the elevation of the highway and to reconstruct the bridges to safely withstand floods having a 50-year recurrence interval. The new bridge and embankment designs have been prepared and approved, but construction has been delayed pending environmental and historical assessments. An opportunity exists to evaluate the designs by utilizing a mathematical simulation of flood flows to determine if the cost of the construction can be decreased.

OBJECTIVES: (1) To assess the proposed bridge and embankment designs for conveying runoff from floods having a 50-year recurrence interval, (2) to explore a more efficient design with respect to the placement and height of the bridges and embankments, and (3) to compare the designs to a no-highway alternative.

APPROACH: The study will involve the use of a two-dimensional finite-element surface-water flow model. Given the inflow and outflow at the limits of the reach, topography, and roughness of the flood plain and geometry of the bridges and embankments, the model can compute the depth and velocity in two dimensions at each node of a network of elements. The network of elements can be detailed sufficiently to represent adequately the opening of the bridges, the location of the embankment, and the location of the main channel. The results from the model can be used to map the water surface, flow distribution, and velocity patterns in the flood plain and in and around the bridge openings. The model simulation will assume steady-state conditions.

PROGRESS: The project is complete. 
PROJECT TITLE: Current and Historical Hydrologic Conditions

of the Edwards-Trinity Aquifer and

Comanche Springs, Pecos County

PROJECT NUMBER: TX 87-105

STUDY LOCATION: Southwest Texas

COOPERATING

AGENCY: City of Fort Stockton

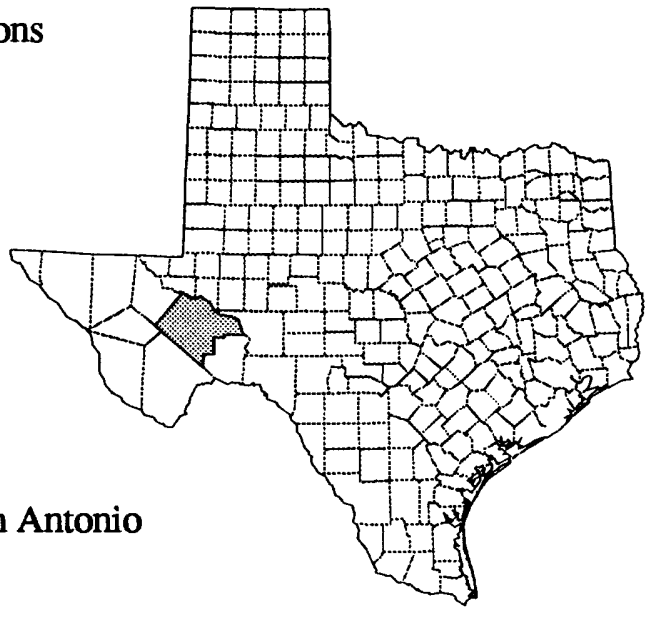

PROJECT DURATION: January 1987 to September 1988

PROBLEM: To assess the possibility of Comanche Springs flowing at significant rates and on a permanent basis, the city of Fort Stockton and Pecos County will need to know (1) the historical conditions of the aquifer system that supplied water to the Springs when it flowed freely; (2) the associated ground-water pumping and water-level declines when the flow began to diminish; and (3) the ground-water pumping that has led to the current water-level and water-quality characteristics of the aquifer system. Independent of the interest in Comanche Springs, a documentation of the current and historical conditions of the water-level and water-quality characteristics of the Edwards-Trinity aquifer system in all of Pecos County is needed to provide a basis for planning and management decisions.

OBJECTIVES: (1) To estimate the predevelopment water levels, (2) to describe the current conditions of the ground-water levels and water-quality characteristics of the aquifer, (3) to define the relation between the ground-water levels and the flow at Comanche Springs, and (4) to illustrate the ground-water flow patterns for the predevelopment and current (1992) water-level conditions.

APPROACH: The approach largely depends on the description of the ground-water resources in reports and data files. These reports and data will provide the basis for framework of the aquifer system and for estimating the historical water-level conditions. The current conditions will be determined by water-level measurements in about 125 wells and for water-quality characteristics in about 30 wells. Wells with historical record will be selected where possible. The water-level monitoring will be done in the winter, when pumpage is the least during the year. Water samples will be collected in the summer. To meet the other stated objectives, much of the data will be mapped and graphed to facilitate the analyses and interpretations using the principles of hydrology and geology and the knowledge of the Edwards-Trinity aquifer system. To the extent possible, the analysis and interpretation will be from predevelopment to the mid-1950's, to the mid-1970's, and to current (1992) time.

PROGRESS: The project is complete except for the report.

PLANS: Publish the report. 
PROJECT TITLE: Analysis of Specific Flow Paths in the Edwards Aquifer, San Antonio Region

PROJECT NUMBER: TX 88-107

STUDY LOCATION: South-central Texas

COOPERATING

AGENCY: San Antonio Water Board

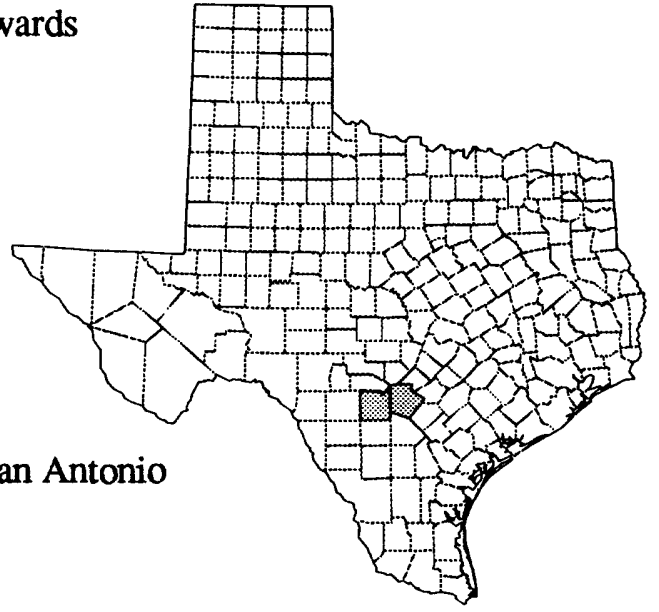

PROBLEM: Defining flow paths and residence times for water along flow paths is made difficult and uncertain as a result of the great anisotropy created by fault barriers. The delineation of flow cannot be made on the basis of the gradients determined by water-level measurements. The largest gradients are located near barrier faults and are apparently steepest across the faults. The location and extent of the faults play a major role in controlling the direction of the flow of the water that enters the aquifer. These regional flow paths and the local complexities play a major role in determining the residence time of water in the aquifer and the potential for contamination to reach supply wells.

OBJECTIVES: (1) To better understand the various structural and stratigraphic characteristics and the control they have on the flow of water, (2) to integrate available information on the structure and geometry of the aquifer in order to infer the major directions of flow down fault blocks and the change in direction of the flow, and (3) to delineate the major paths that a parcel of recharge water would take from the point of recharge until it is discharged near San Antonio or one of the major springs.

APPROACH: There are 12 specific techniques that will be combined: (1) Review literature, (2) study the record of recharge to each subbasin, (3) digitize geologic information (4) determine flow paths of water that is recharged in Bexar County, (5) assemble cross sections along the major flow path leading to San Antonio, (6) fill in details and gaps in the cross sections using other recently (1992) collected data, (7) plot chemical and head data along the flow paths, (8) plot all available tritium data, (9) investigate and apply new tracers or reapply old tracers, (10) level specifically selected wells, (11) review drillers' and geophysical logs, and (12) study the historical range of water levels to determine low water levels in northern Bexar County.

PROGRESS: The water-supply paper was submitted to the supervisor June 13,1991 . The hydrologic atlas report is being revised by G.B. Ozuna, author, following colleague review. The project is complete except for the reports.

\section{PROPOSED REPORTS:}

Groschen, G.E., Analysis of factors controlling flow of water and geochemistry in selected zones of the Edwards aquifer, San Antonio region, Texas: U.S. Geological Survey Water-Supply Paper.

Stein, W.G., and Ozuna, G.B., Hydrogeologic framework of the Edwards aquifer recharge zone, Bexar County, Texas: U.S. Geological Survey Hydrologic Investigations Atlas. 
PROJECT TITLE: Monitoring Ground-Water Levels in the High Plains of Texas

PROJECT NUMBER: TX 88-108

STUDY LOCATION: Northwest Texas

COOPERATING

AGENCY: Texas Water Development Board

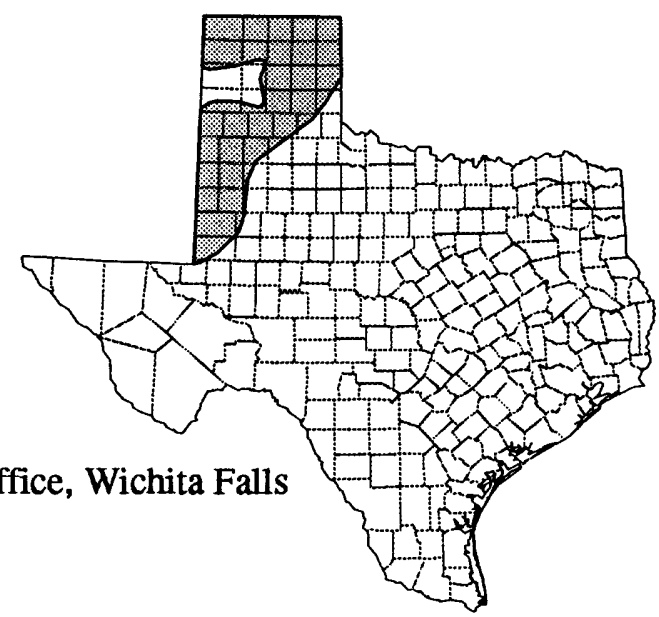

PROJECT DURATION: March 1988 to September 1993

PROBLEM: Because of the continued decline in ground-water levels in much of the High Plains aquifer and its potential long-term impact on the Nation's economy, the U.S. Congress requested the U.S. Geological Survey (USGS) measure the variations of the aquifer's water levels over 5 years to determine the causes and to periodically report the findings to them. These findings are needed to develop watermanagement plans.

OBJECTIVE: The project is to be part of a program for monitoring the water levels in the High Plains aquifer and for explaining the causes for the water-level changes. This project is limited to Texas but is to be coordinated with similar projects in the other High Plains States.

APPROACH: The project will be executed jointly by the USGS and the Texas Water Development Board (TWDB). The network of wells for the project will come mostly from the current network operated by TWDB. The network will be expanded by the USGS to include several wells and recorders for which historical data are available. About six wells will have recorders; several hundred other wells will be measured manually once a year. The data will be entered into the USGS ground-water site inventory (GWSI) data base.

PROGRESS: Operation and maintenance of all data-collection stations and all data-collection tasks were completed for the year. All data were entered into the GWSI system and will be published for the 1992 water year.

PLANS: Operate and maintain the data-collection stations, perform the data-collection tasks, enter the data into GWSI, publish, and assist the regional office in preparing a water-surface map for the winter conditions.

\section{PROPOSED REPORT:}

Land, L.F., and Kidwell, C.C., Ground-water levels in the High Plains aquifer, Texas, 1988-1993: U.S. Geological Survey Open-File Report. 
PROJECT TITLE: Community Structure of Aquatic Organisms in the San Antonio River

PROJECT NUMBER: TX 88-112

STUDY LOCATION: San Antonio, Texas

COOPERATING

AGENCIES: San Antonio Department of Wastewater Management, San Antonio Public Works Department

PROJECT CHIEF: R. Lynn Taylor, District Office, Austin

PROJECT DURATION: August 1988 to September 1996

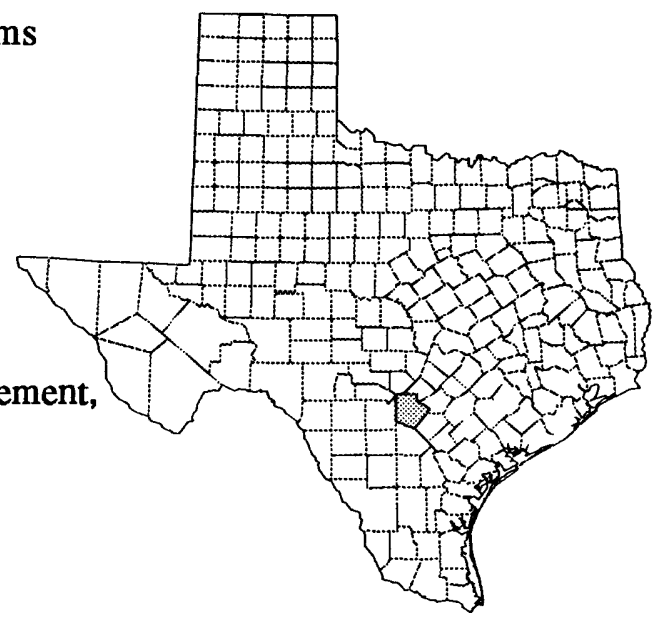

PROBLEM: The City of San Antonio Environmental Management is scheduled to construct a wastewater-treatment plant north of San Antonio International Airport. The city has plans to reuse wastewater from this treatment plant as part of a regional water-supply system for San Antonio. A major use of this water would be to irrigate city owned properties in and around Olmos Basin Park and Brackenridge Park. Return flow from these irrigated areas will enter into Olmos Creek and the San Antonio River. A second planned use is for direct discharge to Olmos Creek to augment flows.

The city of San Antonio wants to be in compliance with water-quality standards established by the Clean Water Act of 1972. Study of the aquatic ecosystem of the San Antonio River could provide a direct indication of water-quality degradation and resultant negative impacts on aquatic biota. Two sites on Salado Creek were added to this study during water year 1991.

OBJECTIVES: (1) To provide baseline physical, chemical, and biological data for Olmos Creek and the San Antonio River in Olmos Basin Park and Brackenridge Park, (2) to determine the effects of wastewater effluent on the aquatic ecosystem in a 2.6 mile reach of Olmos Creek and the San Antonio River downstream from Olmos Park and through Brackenridge Park, and (3) to define causal relations between changes in physical and chemical data and observed changes in the aquatic community. The objectives are the same for the Salado Creek study sites.

APPROACH: Data collection for the project will continue for 7 years--4 years preceding and 3 years following the completed construction of the wastewater-treatment plant near the airport. One sampling site will coincide with a site previously sampled by the San Antonio River Authority during their 1-year ecological assessment of the upper San Antonio River.

The major sampling effort will be done five times each year--twice during low flow in early spring and three times during low flow in the summer. Physical, chemical, and biological sampling will be done at three sites. One site will be in Olmos Creek, just below Olmos Dam. Olmos Dam only operates during flood events to lessen the impact of high flows on the city of San Antonio. Two sites will be in the San Antonio River--one at the northern boundary of Brackenridge Park and one downstream near the southem boundary of Brackenridge Park. A continuous streamflow station has been established at each of these sites.

Trend analysis will be used to indicate changes in water quality after the wastewater-treatment plant is on line. Any changes in water quality will be correlated, if possible, with changes in the biotic community, as indicated by various biotic or diversity indices. Evaluations of the biotic community will 
be based not only on numbers of organism types but also on number of organisms in groups with similar functions in the environment. Correlations between various water-quality constituents and specific types of organisms and organisms with specific functional relations in the community will be examined to define cause and effect relations for observed community changes.

The Salado Creek study follows the approach outlined above for the San Antonio River. The upstream site is located in the northern part of San Antonio at loop 410. The downstream site is located in the southem part of the city at Military Drive. A continuous streamflow-gaging station was already established at each site.

PROGRESS: During five sampling periods, water samples were collected for chemical analyses of major dissolved constituents, nutrients, and trace elements. Because of drought conditions in south Texas, lack of streamflow at the upstream San Antonio River station precluded sampling during one of the sampling periods scheduled for the project. High flows during the end of April and the beginning of May precluded the scheduled sampling at all sites during that sampling period. Water quality was similar among sites for each of the sampling periods; however, nutrient concentrations were largest at the most downstream site in the study area, except nitrate concentrations, which were largest at the middle site. Samples were collected for phytoplankton, periphyton, and benthic invertebrate analyses during each sampling period. Results of biological sample analyses have been received and tabulated from the laboratory for the first 2 years of data. There was flow at both sites on Salado Creek for all sampling periods. High flows in May precluded sampling that month.

PLANS: Prepare data report for the fourth year of effort. Write interpretive report describing the baseline conditions present in the San Antonio River during the first 4 years, unless the treatment plant still is not on line and the city authorizes a fifth year of baseline collection. Reports for data collection on Salado Creek are proposed as part of the San Antonio urban project (TX 90-120).

\section{PROPOSED REPORTS:}

Taylor, R.L., Baseline biological, chemical, and physical data for lower Olmos Creek and the upper San Antonio River, Texas, 1990: U.S. Geological Survey Open-File Report.

Taylor, R.L., Baseline biological, chemical, and physical data for lower Olmos Creek and the upper San Antonio River, Texas, 1991: U.S. Geological Survey Open-File Report.

Taylor, R.L., and Ferreira, R.F., Baseline biological, chemical, and physical data for lower Olmos Creek and the upper San Antonio River, Texas, 1989: U.S. Geological Survey Open-File Report. 
PROJECT TITLE: Study of the Saline Zone of the Edwards Aquifer, San Antonio Region

PROJECT NUMBER: TX 89-113

STUDY LOCATION: South-central Texas

COOPERATING

AGENCY: San Antonio Water Board

PROJECT CHIEF: George E. Groschen, Subdistrict Office, San Antonio

PROJECT DURATION: February 1989 to September 1992

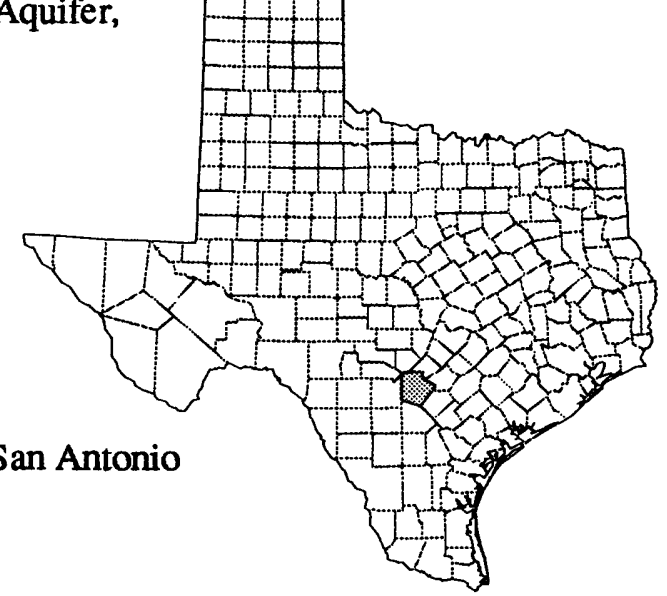

PROBLEM: Saline-water intrusion from the downdip boundary of the Edwards aquifer into the freshwater is hydraulically possible. Because the Edwards aquifer is the sole source of water for more than 1 million people, it is critical to know how rapidly and in what quantity the saline water will move. Should intrusion occur, the highly leached freshwater part of the aquifer may allow rapid mixing of the saline water and contamination of the most productive part of the aquifer, which supplies much of the city of San Antonio and is on the flow path to major springs to the northeast.

OBJECTIVE: To better understand the conditions that control the salinity and hydraulics of the salinewater zone and thereby to assess the potential for saline water to move into the freshwater zone of the aquifer during periods of drought and coincidental depressed water levels.

APPROACH: (1) Develop several working conceptual models of the hydrogeologic framework of the downdip boundary of the Edwards aquifer; (2) develop and test one or several numerical geochemical models with existing and new data. The models will be used to identify the geochemical reactions that dominate or control the development of the aquifer; (3) collect data on water levels, water chemistry, isotopes of several elements, saline-water production, existing petrographic and petrologic information, and salinity profiles in available wells; (4) perform a trend analysis of selected water-quality constituents; and (5) prepare a final report.

PROGRESS: Data compilation was completed. From discussion with the Region, it was decided that two reports would best satisfy the objective. Two report outlines were prepared.

PLANS: Complete report preparation and publish reports.

\section{PROPOSED REPORTS:}

Groschen, G.E., Geology and geochemistry of the saline-water zone of the Edwards aquifer, south Texas: U.S. Geological Survey Water-Resources Investigations Report.

Hydrology of the saline-water zone of the Edwards aquifer, south Texas: U.S. Geological Survey Water-Resources Investigations Report. 
PROJECT TITLE: Light Attenuation and Its Effects on the Quality of Water in Turbid Reservoirs

PROJECT NUMBER: TX 89-116

STUDY LOCATION: Southeast Texas

COOPERATING

AGENCY: City of Houston

PROJECT CHIEF: Walter R. Rast, District Office, Austin

PROJECT DURATION: May 1989 to September 1991

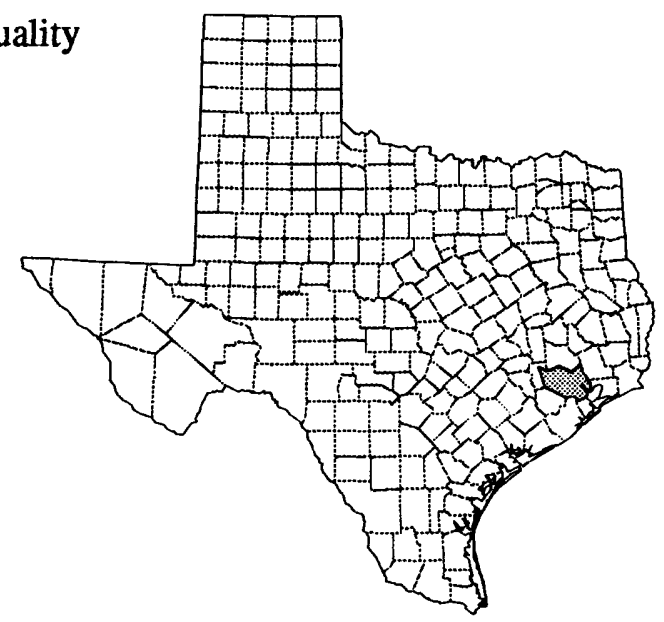

PROBLEM: Studies indicate an understanding of the limnological effects of nonchlorophyll-related light attenuation is essential to understanding the relation between nutrients, algae, and, ultimately, the eutrophication process in reservoir ecosystems. Little effort has been made to assess or to quantify these factors in reservoir systems in the southem and southwestern United States. Consequently, related findings from natural lakes in the north-central and midwestem south and southwest are commonly used for management of water quality.

OBJECTIVES: (1) To measure the water transparency and light-attenuation characteristics of Lake Houston, (2) to identify and measure the organic and inorganic components in the water column that affect or control its light-attenuation capacity, and (3) to quantitatively relate these components to the optical properties of Lake Houston and to the water-quality parameters affected by these components, which include algal biomass and productivity and water transparency.

APPROACH: (1) Quantify the organic and inorganic components in the water column that affect or control the light-attenuation characteristics of Lake Houston; (2) measure the optical properties of Lake Houston over the annual cycle as a function of depth, varying concentrations of chlorophyll, organic and inorganic particulate matter and dissolved color in the water column; (3) quantify the proportions of light-attenuation capacity related to algal pigments, organic and inorganic particulate matter, and dissolved color, (4) statistically relate these causative factors to the measured water transparency and light-attenuation characteristics; (5) statistically contrast the measured light-attenuation and related waterquality characteristics to those of temperate-zone natural lakes; and (6) evaluate the effects of the optical properties and light-attenuation characteristics in regard to assessment of the trophic status and eutrophication-related water quality of Lake Houston.

PROGRESS: The project is complete except for the report.

PLANS: Publish the final report.

\section{PROPOSED REPORT:}

Rast, W.R., Components of light attenuation and water transparency, Lake Houston, Texas: U.S. Geological Survey Water-Resources Investigations Report. 
PROJECT TITLE: Study of Recharge to the Chicot and Evangeline Aquifers Northwest of Houston

PROJECT NUMBER: TX 89-117

STUDY LOCATION: Northwest Houston, Texas

COOPERATING

AGENCY: Harris-Galveston Coastal Subsidence District

PROJECT CHIEF: Dana L. Barbie, Subdistrict Office, Houston

PROJECT DURATION: May 1989 to September 1991

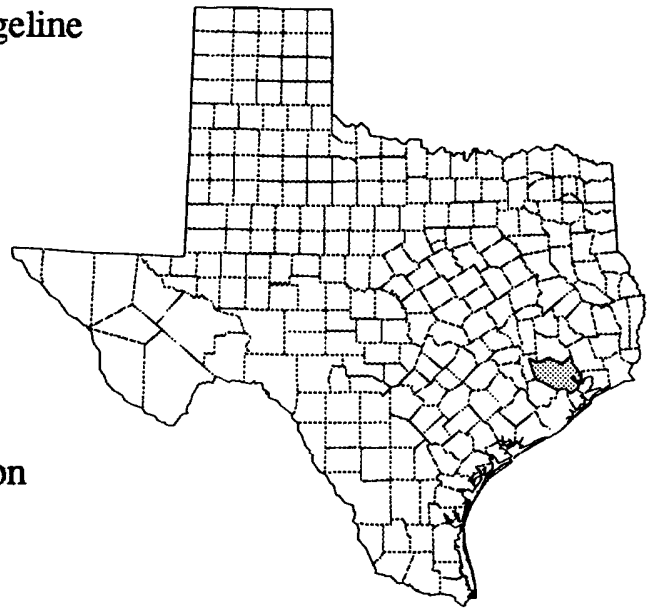

PROBLEM: Many studies of ground-water availability in the Houston area have been done since 1930. These studies have indicated that large volumes of water are being recharged through the outcrops of the Chicot and Evangeline aquifers. However, questions have arisen as to whether most of the water being pumped within the Houston area comes from storage or from recharge through the outcrops of the aquifers.

OBJECTIVES: (1) To define the current depth and estimate the change in depth to the zone of saturation within each aquifer's outcrop, (2) to approximate the rate and magnitude of recharge, and (3) to attempt to characterize the shallow subsurface materials.

APPROACH: The study will emphasize the use of shallow surface geophysics, current and historical water levels, environmental tritium concentrations, and drillers' and electric logs. Geophysical surveys, water-level data, and drillers' logs will be used to determine the depth to the water table within each aquifer's outcrop and possibly, the characteristics of the subsurface materials. These data will be supplemented with test drilling and the installation of clusters of monitoring wells at three sites. The data will greatly support the analysis of the geophysical data. Water samples also will be collected from several wells and analyzed for environmental tritium for dating purposes.

PROGRESS: One hundred twenty surface-refractive geophysical data points were completed. The report was completed and is in review. The project is complete except for the report.

PLANS: Process and publish the report.

\section{PROPOSED REPORT:}

Barbie D.L., Kasmarek, M.C., Locke, G.L., and Campodonico, Al, Recharge through the outcrops of the Chicot and Evangeline aquifers northwest of Houston: U.S. Geological Survey Water-Resources Investigations Report. 
PROJECT TITLE: Evaluation of Methods to Calculate Irrigated Crop Acreages Using Remote-Sensing Data in Uvalde, Medina, and Western Bexar Counties

PROJECT NUMBER: TX 89-118

STUDY LOCATION: South-central Texas

COOPERATING

AGENCY: Edwards Underground Water District

PROJECT CHIEF: Lee H. Raymond, District Office, Austin

PROJECT DURATION: May 1989 to September 1992

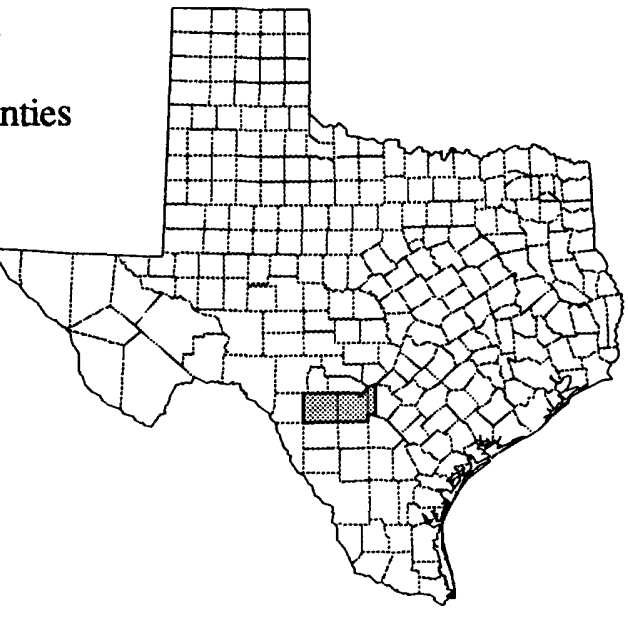

PROBLEM: Ground-water discharge from the Edwards aquifer is evaluated annually as part of the compilation of hydrologic data for the aquifer in a cooperative project by the U.S. Geological Survey and the Edwards Underground Water District. Ground-water discharge from the Edwards aquifer in Uvalde and Medina Counties is used primarily for irrigation of crops. The volume of water applied to irrigated crops is used as an estimate of this discharge. The quantities of irrigated crop acreages for Uvalde, Medina, and western Bexar Counties are difficult to obtain, and a new method of estimating acreage must be developed.

OBJECTIVES: (1) To evaluate methods for identifying crop types and calculating the number of acres of each crop type using remote-sensing data for 1989. The methods to be explored include digital processing of satellite images and visual inspection of aerial photographs; and (2) to develop an operational procedure for calculating irrigated crop acreages in order to estimate the volume of water used to irrigate crops in Uvalde and Medina Counties on an annual basis.

APPROACH: Satellite images will be obtained during early and late summer. Several image-processing techniques will be compared to determine which gives the best separation of crop types and of irrigated from nonirrigated crops in the study area.

PROGRESS: The 1989 analysis was completed and the report was approved in August, 1992. The project was extended through fiscal year 1992, at the request of the cooperator, to evaluate the use of Landsat Thematic Mapper data for the 1991 crop year. Two images were collected and are being processed using image-processing software. A brief report is being written to document these results.

PLANS: Complete the brief report evaluating the 1991 test results.

\section{PROPOSED REPORT:}

Raymond, L.H., and McFarlane, S.I., Evaluation of the use of Landsat Thematic Mapper data to identify crop types and estimate irrigated acreage, Uvalde and Medina Counties, Texas, 1991. 
PROJECT TITLE: Urban Hydrology and Impacts of Water Reuse in San Antonio

PROJECT NUMBER: TX 90-120

STUDY LOCATION: San Antonio, Texas

COOPERATING

AGENCIES: San Antonio Department of Wastewater Management, San Antonio Public Works Department

PROJECT CHIEF: Marshall E. Jennings, District Office, Austin

PROJECT DURATION: October 1989 to September 1994

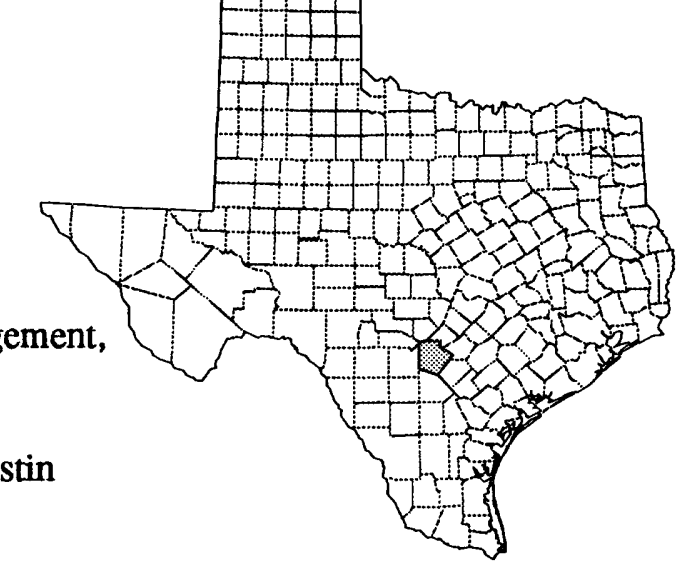

PROBLEM: In order to assist the city of San Antonio with water-reuse planning and water-resources planning, a network of streamflow-gaging and lake stations and associated hydrologic investigations has been proposed. During fiscal years 1990-92, these studies focused on the Salado Creek watershed. Two streamflow-gaging stations, in existence since 1960, will form the initial hydrologic network. Eventually the hydrologic network will extend to other stream systems within the city as part of a multiyear investigation. The entire study area will encompass the stream network affected by the city's water-reuse program. State-of-the-art watershed and hydraulic routing models will be used to construct an urban water-mass balance of the affected watershed systems. The mass balance will include detailed characterization of urban stream and urban lake quality. A separate analysis will be made of urban floodpeak frequency for the San Antonio metropolitan area.

OBJECTIVES: Objectives for fiscal years 1990-92 included work on the Salado Creek watershed system, which will be used as a prototype for further studies of the entire San Antonio urban hydrologic system. Because of the impact on the water balance by the previously uncapped Edwards well, J 21, a special investigation of this well and nearby related water levels was done. Objectives included: (1) Studies to define the low- and high-flow water budget of Salado Creek to near its confluence with the San Antonio River; (2) water-quality sampling for low- and high-flow conditions for the Salado Creek watershed and model-calibration studies using a watershed- and channel-hydraulic transport simulation model; (3) investigation of the relation of $\mathrm{J} 21$ well flow and $\mathrm{J} 17$ water levels. Use of other nearby water levels to establish a predictive relation; and (4) data base preparation and initial model calibration for a regional study of urban flood-frequency characteristics in San Antonio.

APPROACH: (1) Do a series of low-flow gain-and-loss studies using streamflow-measurement techniques during 1990-92. Water-quality samples were taken for key chemical constituents; (2) sample high-flow water quality for one or two typical conditions at the gaging station and National Pollution Discharge Elimination System locations in Salado Creek; (3) calibrate watershed-channel flow models using available data including information collected by the Texas Water Commission; (4) review measurement programs for the $\mathrm{J} 21$ well flow and relations with nearby index wells. As funds permit, accurately measure $\mathrm{J} 21$ well flow for several diurnal periods at different levels of the Edwards aquifer. Relate J 21 well flow to Salado Creek discharge using a control volume approach; and (5) update the data base for flood-frequency data in the San Antonio metropolitan area. Perform initial calibrations of the U.S. Geological Survey (USGS) record-extension urban watershed model on six flood-hydrograph sites.

PROGRESS: A final low-flow, gain-and-loss investigation with water-quality analysis was completed in July 1992. All data are compiled in a project data base for analysis. Preliminary assessment of the 
Hydrologic Simulation Program FORTRAN (HSPF) was made for use with San Antonio urban watershed data. Simulation results for peak-flow frequency using the USGS Rainfall Runoff Model record extension model have been completed. The J 21 well was capped on about October 1, 1991 .

PLANS: Calibrate and verify studies using the HSPF model for Salado Creek and extend to the entire city. Extend data collection and model analyses to adjacent watersheds. Complete citywide floodfrequency analyses for urban watersheds.

\section{PROPOSED REPORTS:}

Jennings, M.E., Rast, W.R., and Pudar, R.S., Urban hydrologic investigations for Salado Creek, San Antonio, Texas: U.S. Geological Survey Water-Resources Investigations Report.

Koch, Tom, and Jennings, M.E., Plans for an urban hydrologic mass-balance simulation approach to evaluate water use, San Antonio, Texas: Poster presented at the Annual Meeting, American Water Resources Association, Denver, Colorado, November 1990.

Johnson, D.W., and Jennings, M.E., Urban flood-frequency analysis for San Antonio, Texas: Paper for Fall Meeting, American Water Resources Association, Texas Section, Fort Worth, Texas, November 1992. 
PROJECT TITLE: Characteristics of Salinity in Lake Kemp

PROJECT NUMBER: TX 90-122

STUDY LOCATION: North-central Texas

COOPERATING

AGENCY: Red River Authority, Wichita Falls, Texas

PROJECT CHIEF: Charles C. Kidwell, Field Headquarters Office, Wichita Falls

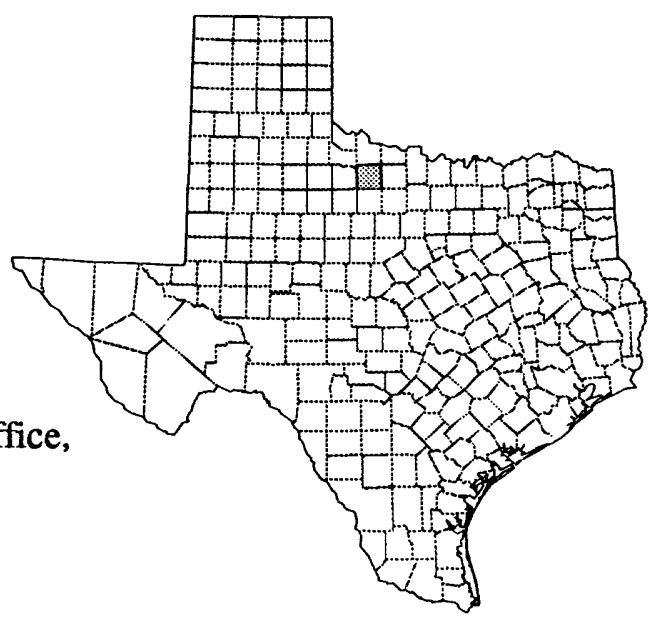

PROJECT DURATION: October 1989 to September 1993

PROBLEM: The U.S. Department of the Army, Corps of Engineers, is diverting highly mineralized water (approximately 20,000 milligrams per liter of dissolved solids) from the South Wichita River into Truscott Brine Lake near Truscott, Texas. During high flow, when water in the river is less mineralized, water is allowed to pass downstream to enter Lake Kemp. The reduction of highly mineralized water into Lake Kemp during periods of low flow, as well as inflow of large volumes of relative dilute water during periods of high flow, should result in a significant reduction of dissolved solids in Lake Kemp in the next several years. To determine the effectiveness of the salt control structure and to supply water managers with information regarding the suitability of water in Lake Kemp, water-quality surveys and analyses of Lake Kemp are needed.

OBJECTIVES: The objectives of this study are to monitor areal and temporal variations in salinity in Lake Kemp for 3 years. At the conclusion of the monitoring period, data will be assembled and interpreted to (1) document the quantity of chloride being diverted by the Chloride Control Project; (2) provide summaries of volume-weighted average concentrations of dissolved solids, chloride, and other select inorganic constituents in Lake Kemp during the 3-year monitoring period; and (3) relate changes in volume-weighted average dissolved solids and dissolved chloride concentrations in Lake Kemp to the quantity of these constituents being diverted by the Chloride Control Project.

APPROACH: Salinity surveys will be done three times per year to determine areal and temporal variations in specific conductance and select major inorganic ions. Salinity profiles will be developed at a minimum of six cross sections. At each cross section, field measurements of dissolved oxygen, specific conductance, temperature, and $\mathrm{pH}$ will be made. Water samples will be collected during the course of the study, over a wide range of conductance values, to determine relations between specific conductance and selected major inorganic ions. Based on these relations, volume-weighted average concentrations of selected inorganic constituents may be determined for the entire reservoir. Dissolved solid loads, dissolved chloride loads, and loads of other select inorganic chemical constituents will be calculated from the continuous monitoring of discharge and specific conductance at the South Wichita River near Benjamin.

PROGRESS: Continue to do three water-quality surveys. All data collection will be completed in August 1992.

PLANS: Prepare and publish the report.

PROPOSED REPORT:

Kidwell, C.C., Characteristics of Salinity in Lake Kemp: U.S. Geological Survey Water-Resources Investigations Report. 
PROJECT TITLE: Renovation of Tertiary-Treated Municipal

Wastewater by Migration through the

Hueco Bolson Aquifer, El Paso

PROJECT NUMBER: TX 90-123

STUDY LOCATION: Northeast El Paso, Texas

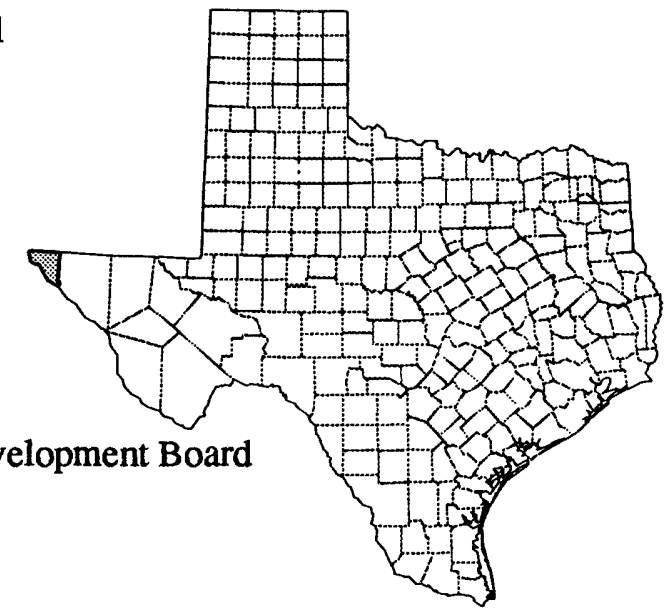

PROJECT DURATION: July 1990 to September 1992

PROBLEM: Because of projected increases in water demand, about 4 billion gallons of tertiary-treated, chlorinated wastewater have been injected into the heterogeneous, unconsolidated alluvial sediments of the Hueco bolson aquifer between 1985-89 as a treatment method. A need exists to determine the effect of the wastewater on the future potability of ground water near the project. The major compounds of interest in the wastewater are the trihalomethanes (THM): Chloroform, dichlorobromomethane, dibromochloromethane, and bromoform. An understanding of the effects of ground-water flow rate, sorptive interactions, and biotransformations on THM residence time and fate is necessary to avoid future limitations on water use.

OBJECTIVES: (1) To define the occurrence and relative retardation of THM compounds with respect to a conservative, anionic or neutral tracer of wastewater; (2) to determine the relation of THM compounds occurrence to redox conditions in ground water; (3) to determine the importance of sorptive interactions with organic carbon in the aquifer on THM distribution; (4) to determine whether biotransformation of THM compounds is a likely process for their removal from the aquifer; and (5) to define the relative importance of processes such as sorption, biotransformation, and physical dilution by mixing with native ground water to the fate of THM compounds.

APPROACH: In component (1), existing geologic, hydrologic, and water-chemistry data will be used to describe the hydrogeologic characteristics of the aquifer. Existing wells will be sampled for potential tracers of injected wastewater and species related to trihalomethane formation. In component (2), the variability of hydrogeologic and geochemical properties of aquifer sediments related to injected wastewater transport will be investigated at two locations. New piezometers at four to five locations and existing wells will be sampled for the same constituents as in component (1). In component (3), a computer simulation will assess the importance of sorption, biotransformation, and mixing-related dilution to the fate of THM compounds in ground water.

PROGRESS: Results from fiscal year (FY) 1990 sampling were used during the second year of the project (October 1991 to September 1992) to locate wells for monitoring progress of the injected water through the aquifer. End-member mixing analysis of the FY 1990 water-chemistry data was used to estimate the relative proportion of injected water to background water at existing wells using boron, chloride, and nitrate concentrations and stable isotopic ratios of oxygen-18 to oxygen-16. Trihalomethane compounds were detected at several production wells in concentrations that are substantially smaller in proportion than that of the injected water. Microbial analyses of water samples indicate that aerobic conditions prevail in ground water. A data report summarizing existing 
hydrogeologic data and water chemistry and microbial data from the FY 1990 samples was prepared. Existing wells were resampled, and a pumpback test was conducted to evaluate geochemical conditions related to THM fate adjacent to the well.

PLANS: Prepare a report that contains an interpretation of the principal processes responsible for attenuation of THM concentrations in the Hueco bolson aquifer, using the results of water chemistry and microbial analyses from FY 1990 and FY 1991 samplings. Conduct a second pumping test to verify the coincidence of below-ambient concentrations of dissolved oxygen and THM compounds near a sampled injection well. These conditions now suggest that THM compounds are biotransformed shortly after injection and are removed from ground water. Drill six observation wells near one of the injection wells during the second quarter of FY 1992. Analyze core samples of aquifer sediments for organic carbon content and the concentration of sorbed trihalomethane compounds. Compile results from these analyses and water chemistry analyses from the new wells with existing hydrogeologic data to simulate the rate of trihalomethane migration through the aquifer.

\section{PROPOSED REPORTS:}

Brock, R.D., Buszka, P.M., and Godsy, E.M., Hydrogeologic data, water quality, and microbial determinations from selected wells near the Hueco bolson recharge project, El Paso, Texas, 1990: U.S. Geological Survey Open-File Report.

Buszka, P.M., Brock, R.D., and Hooper, R.P., Delineation of reclaimed water in the Hueco bolson aquifer by end-member mixing analysis, El Paso, Texas: U.S. Geological Survey WaterResources Investigations Report.

Buszka, P.M., Chlorination by-products from injected, treated wastewater through the Hueco bolson aquifer, El Paso, Texas: U.S. Geological Survey Water-Resources Investigations Report. 
PROJECT TITLE: Assessment of the Potential Effects of HighSalinity Waters on the Highland Lakes

PROJECT NUMBER: TX 90-125

STUDY LOCATION: Central-southeastern Texas

COOPERATING

AGENCIES: City of Austin, Lower Colorado River Authority

PROJECT CHIEF: Walter R. Rast, District Office, Austin

PROJECT DURATION: July 1990 to September 1991

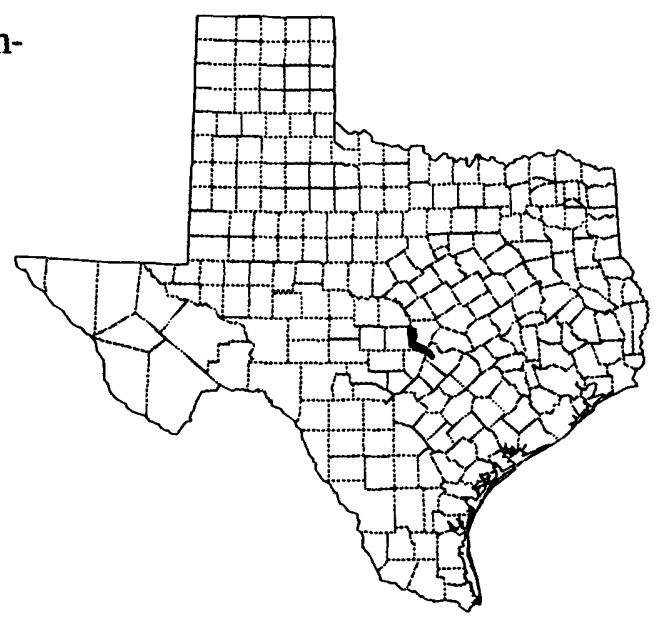

PROBLEM: During 1986-87, unprecedented heavy rains washed hundreds of thousands of tons of salt into E.V. Spence Reservoir in central Texas. Since then, highly saline waters discharged from E.V. Spence Reservoir have entered the upper end of the Highland Lakes, the linearly connected series of seven reservoirs located on the lower Colorado River. These saline waters ultimately will flow through the entire Highland Lakes series, with the potential to significantly affect the water quality of the lakes for many water uses.

OBJECTIVES: (1) To statistically describe the salinity-related water quality of the Highland Lakes; (2) to calibrate the reservoir mass-balance model (RESOP) for analyzing the hydrologic and salinity characteristics of the Highland Lakes; and (3) to predict the potential salinity-related water-quality impacts of selected hydrologic scenarios for the Highland Lakes, and to compare those results with existing Federal and Texas water-quality criteria.

APPROACH: (1) Compile and screen salinity-related water quality and physical data for the Highland Lakes; (2) statistically analyze the salinity-related water quality of the Highland Lakes (Buchanan, Inks, LBJ, Marble Falls, Travis, Austin, and Town); (3) calibrate RESOP; (4) use RESOP to predict the waterquality impacts of the high-salinity waters on the Highland Lakes, as defined by the hydrologic scenarios identified; and (5) compare the predicted water-quality conditions with Federal and Texas quality criteria for drinking water and other relevant water uses.

PROGRESS: The project is complete except for the report.

PLANS: Complete and publish the final report.

\section{PROPOSED REPORT:}

Rast, W.R., Salinity modeling of the Highland Lakes, Texas: U.S. Geological Survey Water-Resources Investigations Report. 
PROJECT TITLE: Streamflow discharges to the Gulf of Mexico

PROJECT NUMBER: TX 90-126

STUDY LOCATION: Lower reaches of the streams that discharge into the Gulf of Mexico

COOPERATING

AGENCY: U.S. Environmental Protection Agency

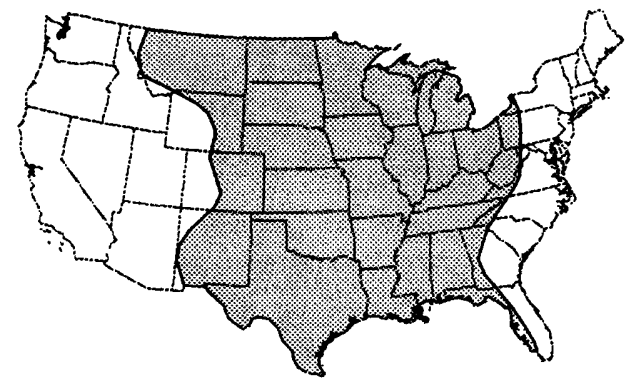

PROJECT CHIEF: Raymond M. Slade, Jr., District Office, Austin

PROJECT DURATION: August 1990 to September 1993

PROBLEM: The U.S. Environmental Protection Agency (USEPA) has initiated the Gulf of Mexico Program with the purpose of developing and implementing a comprehensive strategy for managing and protecting the resources of the Gulf. The strategy will achieve a balance between the needs and demands of human-related activities and the preservation and enhancement of living marine resources in the Gulf. One of the Program subcommittees is responsible for assessing freshwater inflow. The U.S. Geological Survey is conducting studies for the subcommittee in order to meet their objectives.

OBJECTIVES: (1) To characterize streamflow and trends in streamflow to the Gulf of Mexico for each major stream; and (2) to relate the trends in streamflow to changes in precipitation, water impoundments, water use, or land use.

APPROACH: The study addresses several specific objectives, on an annual basis, related to the stated general objective. The 1990 study (a) identifies the availability and extent of the data that may be useful in freshwater inflow studies; (b) divides the area contributing freshwater to the Gulf of Mexico into hydrologic segments; (c) shows the historical trends of streamflow into the bays and estuaries of the Gulf; and (d) identifies existing Federal, State, and regional regulations which affect streamflow into the Gulf of Mexico.

The 1991 study, now completed, (1) presents case studies of temporal trends in streamflow for four basins (Nueces, Trinity, Pearl, and Atchafalaya) that discharge into the Gulf; (2) compares trends in annual-mean, -maximum, and -minimum discharges at 7 to 10 streamflow gages in each basin to trends in associated annual precipitation in each basin for their common periods of records, about 40 to 70 years; (3) compares available data for historic and current surface-water withdrawals to the streamflow trends; and (4) determines the effects of reservoirs on streamflow characteristics; some of the gages selected for the analyses are upstream and downstream from those reservoirs.

The 1992 study is being prepared and will determine and present seasonal trends in streamflow to the Gulf for each of 44 major streams identified in the first report. Trends will be determined for annualmean, -maximum, and -minimum discharges for each stream on a monthly basis. A statistical summary of the trends will be presented, and graphical representations of selected trends will be presented in the report.

A fourth study will be conducted in 1993. The major objective of this study is to determine and present distributions in seasonal (monthly) streamflow to the Gulf of Mexico for each of the 44 major streams identified in the first report. The distributions will be based on an early and late period for each season so that temporal changes in the streamflow may be identified. 
PROGRESS: The report for the 1992 study has been approved. Most of the analyses for the third report were completed.

PLANS: Complete the reports and have them approved for release. Begin analyses on the fourth report.

\section{PROPOSED REPORTS:}

Greene, K.E., and Slade, R.M., Jr., Status of the Gulf of Mexico: Case studies on trends in streamflow, precipitation, and surface-water withdrawals, and effects of reservoirs: U.S. Geological Survey Administrative Report to the freshwater inflow subcommittee of the Gulf of Mexico Program, U.S. Environmental Protection Agency.

Jennings, L.J., and Slade, R.M., Jr., Status of the Gulf of Mexico: Trends in monthly-mean, -minimum, and -maximum inflow from streams: U.S. Geological Survey Administrative Report to the freshwater inflow subcommittee of the Gulf of Mexico Program, U.S. Environmental Protection Agency. 
PROJECT TITLE: National Water Quality Assessment (NAWQA):

Trinity River Basin Study Unit

PROJECT NUMBER: TX 91-127

STUDY LOCATION: North-central and southeast Texas

COOPERATING

AGENCY: None--U.S. Geological Survey funds only

PROJECT CHIEF: Larry F. Land, District Office, Austin

PROJECT DURATION: Continuous since October 1990

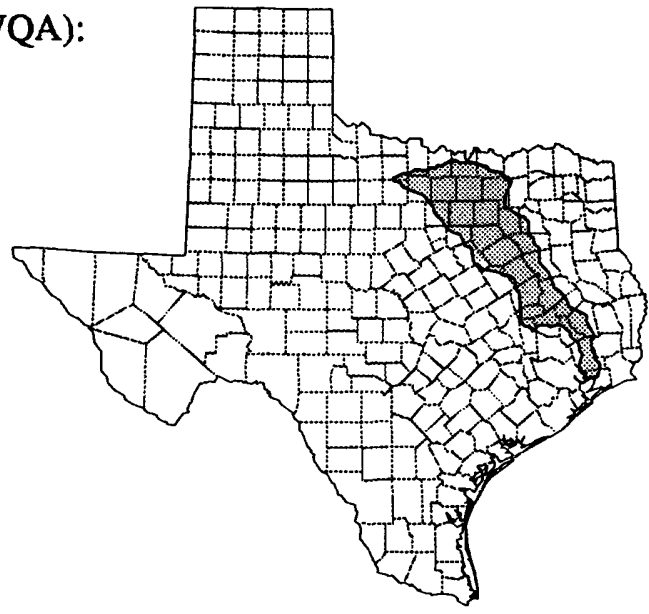

PROBLEM: There is a need for a description of the status and trends in the quality of the Nation's ground- and surface-water resources for the development of a local, regional, and national understanding of what natural and human factors affect the water-quality conditions and trends.

OBJECTIVES: (1) To provide a consistent description of current water-quality conditions; (2) to define long-term trends in water quality; and (3) to identify, describe, and explain the major factors that affect observed water-quality conditions and trends.

APPROACH: Phase I of the project consists of compiling and analyzing existing water-quality data and ancillary data with the goal of characterizing the environmental setting and the historical water-quality conditions in the basin. Phase II consists of data collection and hydrologic and biologic investigations. The major goal of these efforts is to determine the conditions and characteristics of the surface water, ground water, bed sediments, tissue of aquatic animals, and biological communities and habitats.

PROGRESS: The project unit staffing is very nearly complete. All significant sources of water-quality data have been compiled into a computerized data base. A substantial part of these data have been graphed for study and analysis. The compilation, review, and formatting of ancillary data are nearly complete. Two phases of work plans have been prepared and reviewed. Plans are being formulated on the designs and locations of the data collection networks. Field reconnaissance is underway, as is planning for a sediment survey of Lake Livingston. The environmental setting report is in first draft, an annotated outline has been prepared for the nutrient retrospective report, and data have been compiled for the pesticide retrospective report.

PLANS: Focus primarily on data collection, involving all components of the project, including scheduled and event monitoring of streams, occurrence and distribution surveys for contaminants in surface and ground water and sediment and animal tissue along streams, and characterizing the biologic communities and habitats along streams. Several reports of the surveys are expected but are not yet planned.

\section{PROPOSED REPORTS:}

Ulery, R.L., and Brown, M.F., Water-quality assessment of the Trinity River Basin--Analysis of available information on pesticides, 1970-90: U.S. Geological Survey Open-File Report.

Van Metre, P.C., and Reutter, D.C., Water-quality assessment of the Trinity River Basin--Analysis of available information on nutrients and suspended sediment, 1972-1990: U.S. Geological Survey Open-File Report.

Ulery, R.L., Van Metre, P.C., and Crossfield, A.S., Environmental setting and implications for water quality, the Trinity River Basin, Texas: Journal article. 
PROJECT TITLE: Geology and Hydrology of the Edwards Aquifer in the Uvalde and Knippa Area, Uvalde County

PROJECT NUMBER: TX 91-128

STUDY LOCATION: Uvalde County, Texas

COOPERATING

AGENCY: San Antonio Water Board

PROJECT CHIEF: George E. Groschen, Subdistrict Office, San Antonio

PROJECT DURATION: October 1990 to September 1994

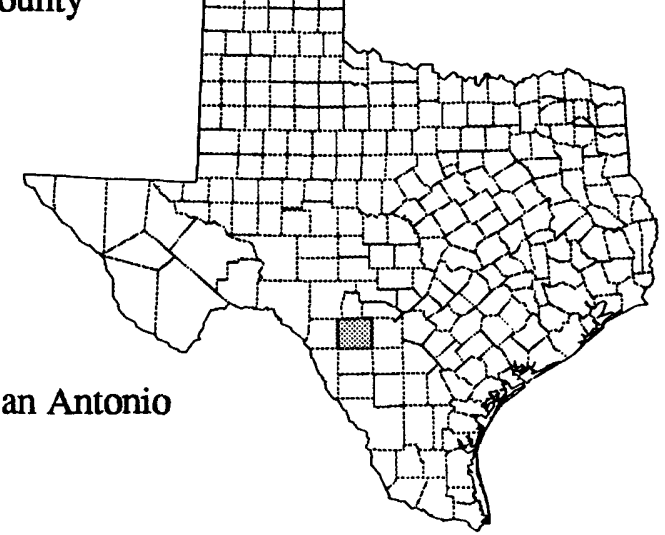

PROBLEM: More and more water is withdrawn from the Edwards aquifer by municipalities and irrigators in the San Antonio area and surrounding counties. Studies need to determine if (1) the geological and structural complexity of the area underlying the cities of Uvalde and Knippa in Uvalde County prevent water from flowing eastward from the western recharge areas, and (2) recharge that enters the aquifer in Uvalde and Kinney Counties is diverted to aquifers overlying the Edwards aquifer.

OBJECTIVES: (1) To describe structural and stratigraphic characteristics of the Edwards aquifer in the area; (2) to determine the flow patterns in the aquifer; (3) to determine the relations among the Edwards, alluvium aquifer, and other minor aquifers in the area; and (4) to estimate the volume of water in storage under varying conditions and estimate a ground-water budget.

APPROACH: (1) Compile existing well-inventory, geologic, water level, and other information; (2) determine the utility of refraction seismic data for mapping water tables or alluvium thickness, or both, and carry out. Reconnaissance level hydrogeologic mapping will be done in Uvalde County; (3) collect water-level and water-quality data from all aquifers; (4) develop a preliminary 3-dimensional groundwater flow simulation of the area; and (5) collect well withdrawal data from all aquifers and streamflow measurements on the Leona and Nueces Rivers.

PROGRESS: Well inventory was 50-percent completed. Mass water-level measurements were made. Fifteen water-quality samples were taken and analyzed. Data compilation was initiated.

PLANS: Complete well inventory. Complete data compilation. Make several mass water-level measurements. Test applicability of seismic techniques for thickness and water levels.

\section{PROPOSED REPORT:}

Groschen, G.E., Geology and hydrology of the Uvalde-Knippa area: U.S. Geological Survey WaterResources Investigations Report. 
PROJECT TITLE: Statistical and Graphical Summary of Selected Water-Quality Data from Buffalo Bayou, Houston

PROJECT NUMBER: TX 91-129

STUDY LOCATION: Houston, Texas

COOPERATING

AGENCY: City of Houston

PROJECT CHIEF: Richard L. Goss, Subdistrict Office, Houston

PROJECT DURATION: October 1990 to September 1992

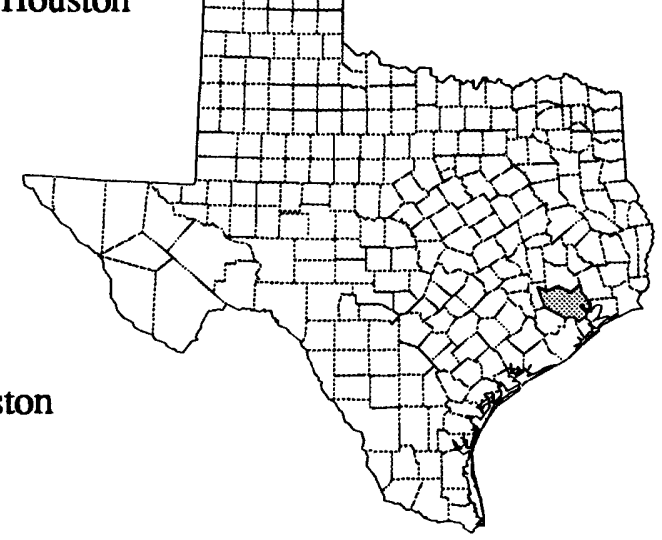

PROBLEM: Buffalo Bayou is the major stream that drains the Houston metropolitan area. Much of the bayou's length is through downtown Houston. The city would like to maintain this part of the bayou in a state which would be beneficial to the city and residents and attractive to visitors to the area. The U.S. Geological Survey has provided water-quality information to the city for three minimonitor sites along Buffalo Bayou since 1986. These sites have been used to collect data for stage and for three waterquality properties (specific conductance, temperature, and dissolved oxygen).

OBJECTIVE: This study will contain a summary of water-quality data that have been collected at the three minimonitor sites along Buffalo Bayou (at Shepherd Drive, Main Street, and the Turning Basin) from April 1986 to March 1991.

APPROACH: Standard statistical summaries, such as mean, standard deviation, maximum, minimum, and selected percentiles will be prepared for each constituent at all three sites using daily values and instantaneous values of maximum and minimums. These statistical summaries will be done for three classification conditions: (1) The entire data set, (2) data classified by runoff conditions, and (3) seasonal classification of data. Trends will be explored by using standard nonparametric statistical methods such as Seasonal Kendall test and Mann-Whitney-Wilcox rank sum test. Plots will be prepared to illustrate the data. Box plots will be used to show differences among the sites. Plots of diumal patterns will be displayed for each site. An attempt will be made to correlate mean daily wind data with mean daily averaged readings of specific conductance, temperature, and dissolved oxygen.

PROGRESS: Data have been collected, analysis has begun, and the report has been started.

PLANS: Publish the report.

PROPOSED REPORT:

Brown, D.W., and Paul, E.M., Statistical and graphical summary of selected water-quality data from Buffalo Bayou at Houston, Texas: U.S. Geological Survey Open-File Report. 
PROJECT TITLE: Evaluation of Potential Bridge Scour in Texas

PROJECT NUMBER: TX 91-130

STUDY LOCATION: Statewide

COOPERATING

AGENCY: Texas Department of Transportation

PROJECT CHIEF: David D. Dunn, District Office, Austin

PROJECT DURATION: March 1992 to September 1994

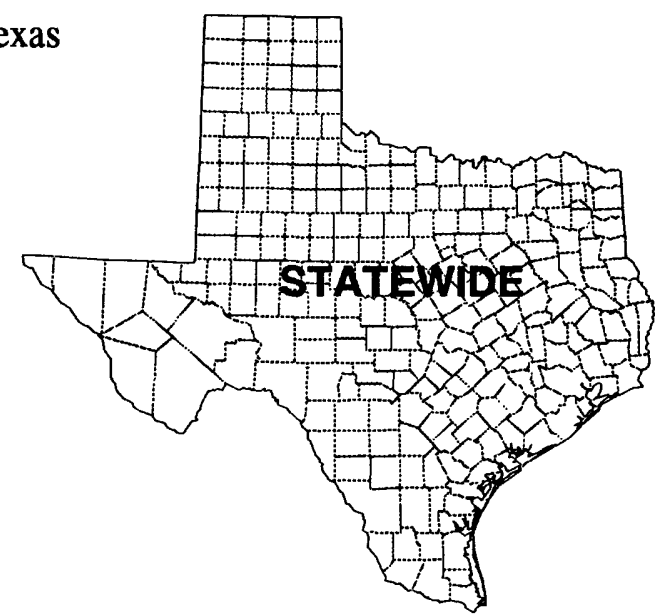

PROBLEM: The Federal Highway Administration has established a requirement, on the Federal Aid System, that all State highway agencies evaluate the bridges that cross water for susceptibility to scourrelated failure. A schedule has been proposed that will have all on-system bridges screened and evaluated for scour susceptibility within the next few years. In the State of Texas, there are more than 11,000 bridges over water. An assessment by the Texas Department of Transportation (TXDOT) indicates that as many as 8,000 of these bridges may be susceptible to scour because of inadequate foundations or unstable river-channel conditions. Because there is such a large number of State-owned bridges and limited resources to repair or replace them, an efficient procedure of identifying and evaluating scour-susceptible bridges is needed. Such a procedure should complement and extend TXDOT procedures for bridge evaluation. The U.S. Geological Survey (USGS) has the capability and interest to assist TXDOT in hydraulic assessments related to bridge scour.

OBJECTIVES: (1) To evaluate existing methods for determining potential for scour at bridges; (2) to assist TXDOT in identifying structures that are scour critical; and (3) to assist TXDOT in the development of a scour analysis procedure to be used by its various local districts in evaluating bridges in their respective jurisdictions.

APPROACH: About 170 bridges in various regions of the State have been identified by local TXDOT districts as being scour susceptible. (1) Perform a cursory Level I analysis at each bridge in fiscal year (FY) 1991 based upon the procedure developed by the Tennessee District of the USGS. The Tennessee Level I analysis will be investigated for adoption by TXDOT as a screening tool with modifications to adapt the procedure to conditions in Texas. (2) Perform Level II analyses on about 20 of the bridges following guidelines developed by the Federal Highway Administration. A Level II analysis consists of bridge hydraulic and ultimate scour depth calculations performed for specified recurrence-interval or overtopping peak discharges. Twelve Level II analyses will be performed in FY 1991, and an additional six Level II analyses will be performed in FY 1992. The Level II analysis method will be evaluated and modifications to the method will be investigated for adoption by TXDOT. (3) Perform a Level III analysis in FY 1991, and another in FY 1992, at selected bridge sites. A Level III analysis is performed using a mobile bed computer model simulation to determine long-term bed elevation changes in response to stresses made to the river system.

PROGRESS: About 140 Level I analyses were performed and entered into the scour data base. The remainder were replaced by several scour measurements made during the flooding, which occurred during December 1991 and January 1992. The scour measurements were compiled into an administrative data report and given to TXDOT and to the Office of Surface Water for entry into the national bridge scour data base. Twelve Level II analyses were completed, and the scour analyses reports were 
transmitted to TXDOT June 1, 1992 as data reports for their review. A bridge failure, which occurred near San Antonio May 18, 1992, is being documented with (1) indirect measurement of peak discharge, (2) ground-penetrating radar to determine the extent of the scour formed by the flood, and (3) Level II analysis. Work is progressing on the additional six Level II analyses.

PLANS: Investigate various methods to lessen the amount of expensive field work (primarily surveying) with the 18 Level II analyses to determine if the procedures can be streamlined for cost efficiency. Perform additional Level II and Level III analyses. Establish guidelines to identify procedures and report formats to be used by the local TXDOT districts as they begin performing Level II analyses of bridges in their jurisdictions. 
PROJECT TITLE: Hydrogeologic Mapping of the Edwards Aquifer Recharge Zone, Hays and Comal Counties

PROJECT NUMBER: TX 91-131

STUDY LOCATION: Central Texas

COOPERATING

AGENCY: Edwards Underground Water District

PROJECT CHIEF: Theodore A. Small, Subdistrict Office, San Antonio

PROJECT DURATION: March 1991 to March 1994

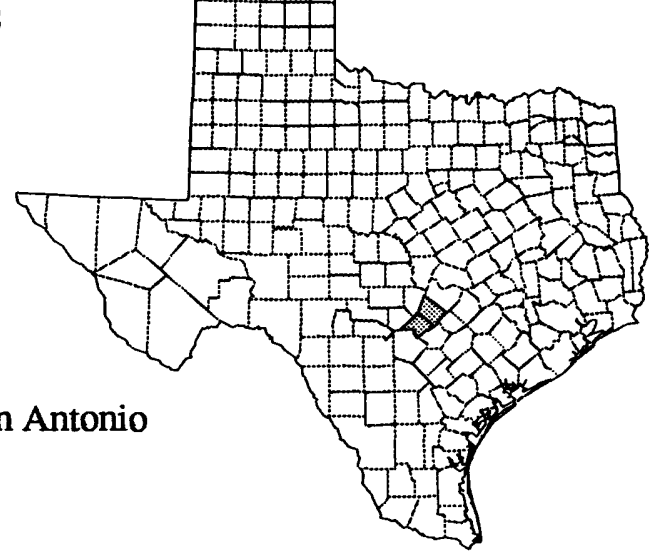

PROBLEM: The hydrogeology of the Edwards aquifer recharge zone in Hays and Comal Counties has not been specifically delineated. A knowledge of these controls on the aquifer is important for the proper development, management, and protection of the aquifer.

OBJECTIVE: To identify and map the hydrogeologic features of the Edwards aquifer recharge zone in Hays and Comal Counties in detail to better understand the processes controlling the flow of water into and through the aquifer.

APPROACH: All existing well logs and available geologic maps of the area will be compiled and used in the mapping process. The Edwards Group will be mapped using eight hydrostratigraphic subdivisions. Field observations of the hydrostratigraphic units, along with caves and other karst features, will be located and delineated on topographic maps.

PROGRESS: Report outline and work plan were completed. Mapping is being completed.

PLANS: Complete mapping. Digitize topographic field map of geology in Comal County.

PROPOSED REPORTS:

Ozuna, G.B., and Small, T.A., Hydrogeologic framework of the Edwards aquifer recharge zone, Comal County, Texas: U.S. Geological Survey Water-Resources Investigations Report, map. Hydrogeologic framework of the Edwards aquifer recharge zone, Hays County, Texas: U.S. Geological Survey Water-Resources Investigations Report, map. 
PROJECT TITLE: Nonpoint-Source Contamination and Eutrophication of the Sandy Creek Embayment of Lake Travis

PROJECT NUMBER: TX 91-132

STUDY LOCATION: Central Texas

COOPERATING

AGENCY: Lower Colorado River Authority

PROJECT CHIEF: Walter R. Rast, District Office, Austin

PROJECT DURATION: January 1991 to September 1993

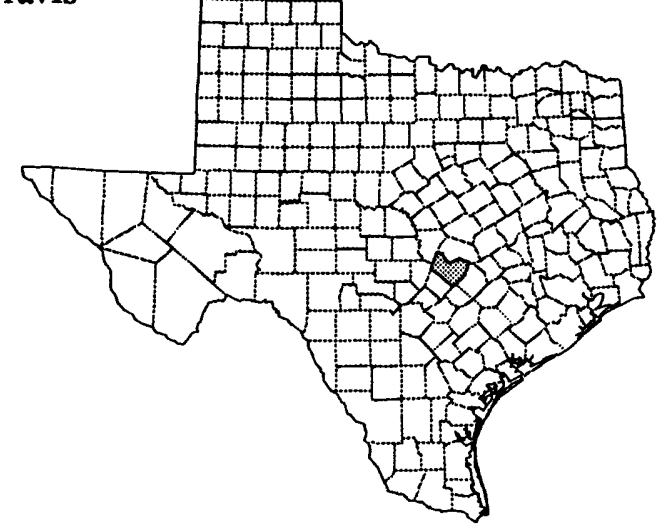

PROBLEM: Lake Travis, one of the Highland Lakes of central Texas, has exhibited increasing degradation over the past decade, primarily from nonpoint contaminant sources in its drainage basin. The Lower Colorado River Authority (LCRA) enacted a basinwide nonpoint-source control ordinance to attempt to alleviate that degradation. However, because of the inherent difficulty in assessing water quality in reservoirs on a whole-lake basis, an embayment of Lake Travis (Sandy Creek arm) is being used as an "early-warning system" to assess (1) the potential water-quality and trophic impacts of nonpoint-source contaminants in its sub-watershed, and (2) the general effectiveness of the LCRA nonpoint-source ordinance.

OBJECTIVES: (1) To assess the water quality and trophic status of the Sandy Creek embayment, and (2) to relate these conditions to nonpoint-contaminant sources in its drainage basin.

APPROACH: (1) Measure water-quality and trophic parameters in the Sandy Creek arm, (2) apply a hydrodynamic and water-quality model to assess the impacts of nonpoint-source contaminant loads to the embayment, and (3) relate the measured and predicted water-quality and trophic condition of Sandy Creek arm to the whole reservoir.

PLANS: During early fiscal year (FY) 1992, install four tributary sampling sites and begin the tributary sampling program. Continue the water-quality monitoring program in the Sandy Creek arm. Calibrate the water-quality model, CE-QUAL-W2 with data from the FY 1991 and FY 1992. Make initial reconnaissance runs with the model. Sample a minimum of four storm events, on the tributaries and in the Sandy Creek arm. Based on initial data analyses, make any necessary adjustments to the tributary and in-cove monitoring program.

\section{PROPOSED REPORT:}

Rast, W.R., Lamon, Conrad, and Slade, R.M., Jr., Assessment of water quality and monitoring program of Lake Travis, Texas: U.S. Geological Survey Water-Resources Investigations Report. 
PROJECT TITLE: Flood-Flow Characteristics for Selected Watersheds in the West Fork Trinity River Basin

PROJECT NUMBER: TX 91-133

STUDY LOCATION: North-central Texas

COOPERATING

AGENCY: Tarrant County Water Control and Improvement District No. 1

PROJECT CHIEF: T.H. Raines, Subdistrict Office, Fort Worth

PROJECT DURATION: October 1990 to September 1994

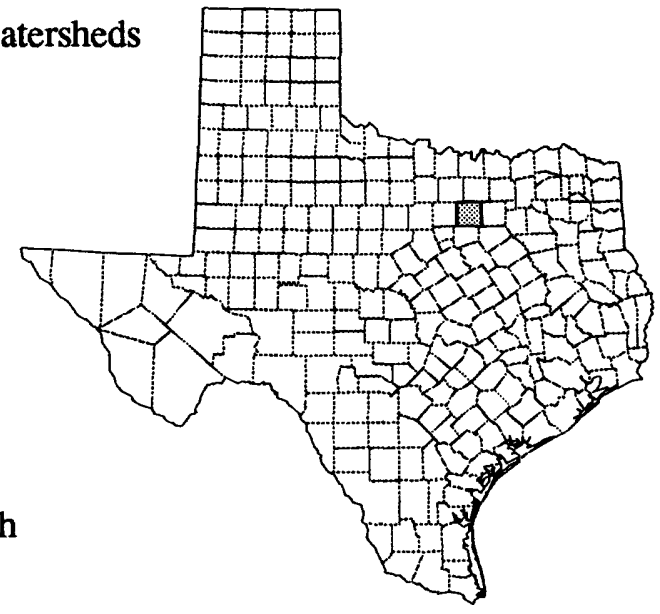

PROBLEM: Recent flooding in the West Fork Trinity River Basin above Lake Worth in Tarrant County, Texas, has caused extensive damage to public and private property, and has resulted in a need for improved flood forecasting in the basin. Accurate estimates of the watershed flows for up to 30 subbasins are required for input into the river channel routing simulation model, operated by the Tarrant County Water Control and Improvement District No. 1.

OBJECTIVE: To develop a watershed flow model that will provide input flow data to the cooperator's channel flood routing model.

APPROACH: To incorporate available knowledge about basin processes into a conceptual model of the system and to compare model-simulated results with observed data, such as streamflow.

PROGRESS: Supplies and equipment have been acquired. The Texas Highway Department will approve shelter design.

PLANS: In early fiscal year (FY) 1992, install two of the five gages. Collect data at the sites and plot and analyze stage-discharge relation. Possibly, later in FY 1992, install the three remaining gages. As hydrologic data are gathered at the newly gaged sites, collect, analyze, and tabulate information on the physical and hydraulic properties of the gaged subbasins. Use data collected in FY 1991 to develop a basinwide rainfall-runoff model that will provide input for the cooperator's main-stem channel routing model.

\section{PROPOSED REPORT:}

Raines, T.H., Characterization and simulation of rainfall-runoff relations for selected watersheds in the West Fork Trinity River Basin, Texas: U.S. Geological Survey Water-Resources Investigations Report. 
PROJECT TITLE: Estimation of Artificial Recharge from Retention Structures in the Edwards Aquifer Recharge Zone near San Antonio

PROJECT NUMBER: TX 91-134

STUDY LOCATION: Fifty miles west-northwest of San Antonio COOPERATING

AGENCY: Edwards Underground Water District

PROJECT CHIEF: Gregory M. Nalley, Subdistrict Office, San Antonio

PROJECT DURATION: April 1991 to September 1994

PROBLEM: The Edwards aquifer is subject to increased stress from a growing population. Methods to increase the availability of water will be determined and reviewed. One such method is to enhance natural recharge by means of retention structures. However, there is little documentation available concerning the overall contribution of enhanced recharge provided by the presence of these retention structures.

OBJECTIVES: (1) To estimate the amount of recharge within a small basin from basin losses and the amount directly attributable to the presence of retention structures, and (2) to estimate recharge at each retention structure for current and pre-dam conditions.

APPROACH: A monitoring network of streamflow gages has been established to determine the discharges above and below retention structures as well as the reservoir stage. Estimated long-term recharge will be determined for the stream reaches above and below each retention structure. Pre-dam conditions will be contrasted with current estimates of recharge. Channel losses will be estimated by determining the current channel losses in the immediate stream reaches. Data pertinent to geology, hydrology, and karst features will be collected. A watershed model will be used to estimate the longterm flows at each retention structure prior to the structure being constructed.

PROGRESS: All gages were installed, and monitoring has begun. Cross sections and levels were run. Rating was made on San Geronimo and Seco Creeks. Four drainage area basins were delineated.

PLANS: Continue data collection. Prepare report outline. Develop capacity curves for all four basins. 
PROJECT TITLE: Evaluation of the Effects of Rangeland Management Practices on Water Quality and Quantity in the Seco Creek Basin near San Antonio

PROJECT NUMBER: TX 91-135

STUDY LOCATION: Fifty miles west-northwest of San Antonio

COOPERATING

AGENCY: Texas State Soil and Water Conservation Board

PROJECT CHIEF: Gregory M. Nalley, Subdistrict Office, San Antonio

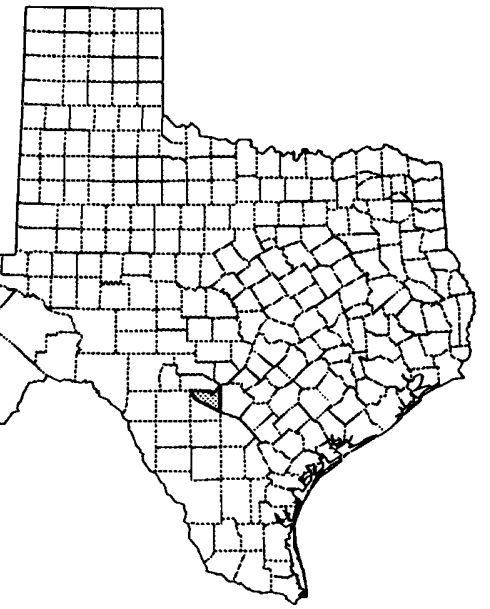

PROJECT DURATION: April 1991 to September 1994

PROBLEM: The Edwards aquifer is subject to increases in use and nonpoint-source contamination from changes in land use or management practices. Methods to maintain or improve the quality or quantity, or both, of water available for recharge to the Edwards aquifer are necessary for future population demands. The U.S. Department of Agriculture, in an effort to identify these relations, established the Seco Creek Demonstration Project.

OBJECTIVE: To assess the impact on water quality, quantity, sediment loading, and recharge rates resulting from the implementation of a Best Management Practices plan conducted within the Seco Creek Basin.

APPROACH: Monitoring stations have been established in order to determine baseline levels of discharge and water quality. As best management practices are implemented, subsequent runoff events will be monitored for changes in water quality, quantity, and sediment loading. The sampling efforts will consist of three sets of water-quality samples and six sediment samples over the hydrograph five times a year. Recharge will be determined from monitoring efforts at the recharge reservoirs and will be evaluated for any changes.

PROGRESS: Thirty-five water-quality and twenty-five sediment samples were collected at four sites. Forty-five stream discharge measurements have been made, and five gage height/discharge relations have been established or redefined. Ninety-five percent of well inventory was completed. Report outline draft has been prepared.

PLANS: Continue data collection. Prepare annotated report outline. Complete well inventory. Develop geographic information system layers. Calibrate model.

\section{PROPOSED REPORT:}

Nalley, G.M., Effect of rangeland management practices on water quality and quantity in the Seco Creek Basin, Texas: U.S. Geological Survey Water-Resources Investigations Report. 
PROJECT TITLE: Trends in Bacteria and Nutrient Concentrations in Tributaries of the North Bosque River, Erath and Hamilton Counties, 1991-94

PROJECT NUMBER: TX 91-136

STUDY LOCATION: North-central Texas

COOPERATING

AGENCY: Texas State Soil and Water Conservation Board

PROJECT CHIEF: Jeffrey T. Sandlin, Subdistrict Office, Fort Worth

PROJECT DURATION: May 1991 to September 1995

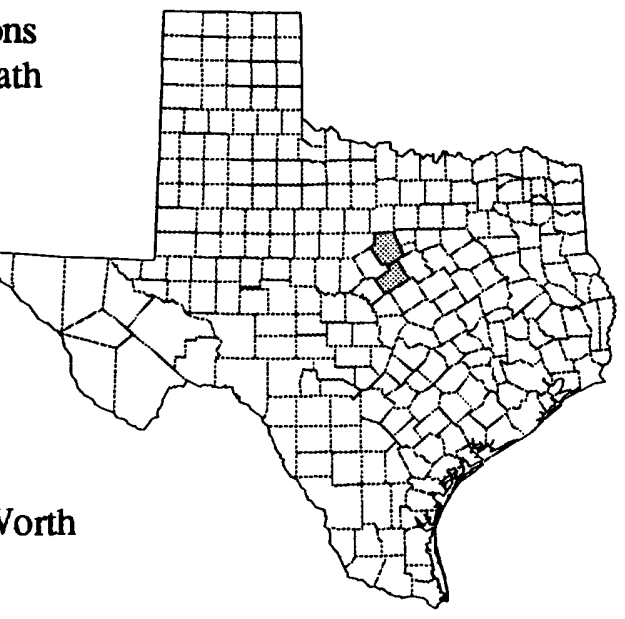

PROBLEM: The potential exists for large-scale nonpoint pollution by fecal bacteria and nutrients from the dairy industry in the upper reaches of the North Bosque River Basin in Erath and Hamilton Counties, Texas.

OBJECTIVE: To determine temporal trends in nonpoint pollutants--specifically, fecal bacteria and nutrients--in surface runoff in tributaries of the North Bosque River drainage basin.

APPROACH: (1) Collect water samples at five sites in small subbasins and on the main stem of the North Bosque River Basin, and (2) conduct trend analysis of the data using various statistical and graphical techniques. The principal statistical techniques to be used for trend analysis will be the qualitative variables in regression analysis and ordinary least squares regression analysis.

PROGRESS: Several samples have been collected at five study sites. Automatic samplers have been installed at two sites.

PLANS: Continue to collect and analyze water-quality data at study sites. Install a third automatic sampler.

\section{PROPOSED REPORT:}

Sandlin, J.T., Trends in bacteria and nutrient concentrations in tributaries of the North Bosque River, north-central Texas, 1991-94: U.S. Geological Survey Water-Resources Investigations Report. 
PROJECT TITLE: Trends in Bacteria and Nutrient Concentrations in Tributaries to Lake Fork Reservoir, Hopkins, Rains, and Wood Counties, 1991-94

PROJECT NUMBER: TX 91-137

STUDY LOCATION: Northeast Texas

COOPERATING

AGENCY: Texas State Soil and Water Conservation Board

PROJECT CHIEF: Glenn A. Rivers, Subdistrict Office, Fort Worth

PROJECT DURATION: March 1991 to September 1995

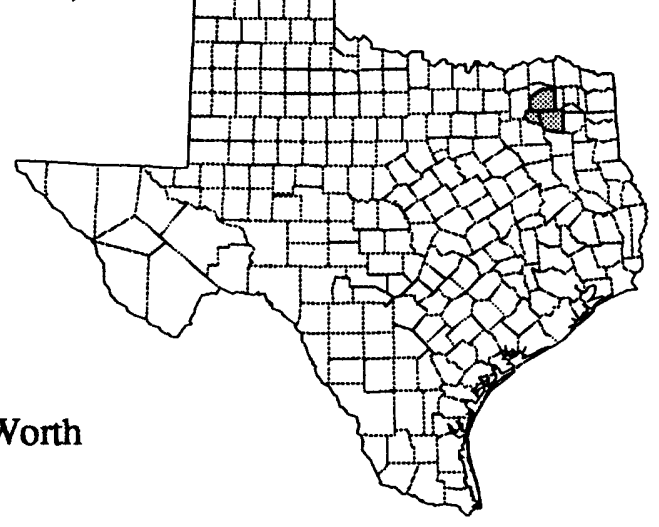

PROBLEM: The potential exists for large-scale nonpoint pollution by fecal bacteria and nutrients from the dairy industry in the Lake Fork Reservoir drainage basin in Hopkins, Rains, and Wood Counties, Texas.

OBJECTIVE: To determine temporal trends in nonpoint pollutants--specifically, fecal bacteria and nutrients--in surface runoff in tributaries to Lake Fork Reservoir.

APPROACH: (1) Collect water samples at the mouths of three small subbasins that drain into Lake Fork Reservoir, and (2) conduct trend analysis of the data using various statistical and graphical techniques. The principal statistical techniques to be used for trend analysis will be the qualitative variables in regression analysis.

PROGRESS: Water-quality samples have been collected at three study sites.

PLANS: Continue to collect and analyze water-quality data at all study sites.

\section{PROPOSED REPORTS:}

Rivers, G.A., Lake Fork water quality: U.S. Geological Survey Water-Resources Investigations Report. Trends in bacteria and nutrient concentrations in tributaries to Lake Fork Reservoir, Hopkins, Rains, and Wood Counties, 1991-94: Water-Resources Investigations Report. 
PROJECT TITLE: Agricultural and Chemical Contamination of a Shallow Aquifer System in North-Central Texas

PROJECT NUMBER: TX 91-138

STUDY LOCATION: Near Gilliland, Knox County, Texas

COOPERATING

AGENCY: Texas State Soil and Water Conservation Board

PROJECT CHIEF: James R. Bartolino, District Office, Austin

PROJECT DURATION: July 1991 to September 1994

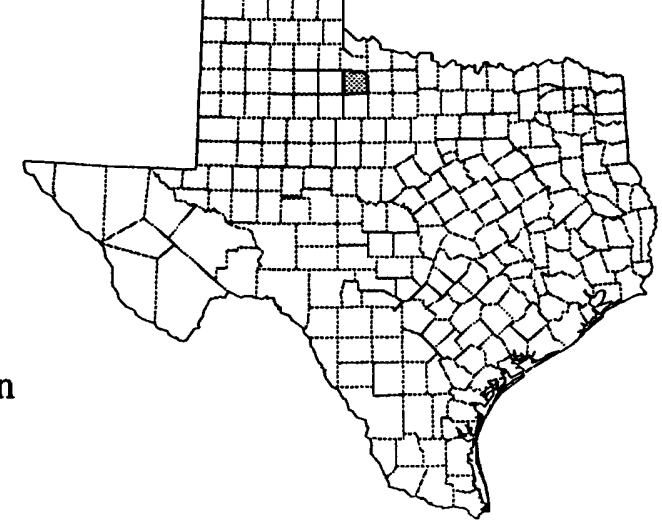

PROBLEM: Residents in and around the community of Gilliland, Texas, expressed concern about the potential contamination by agricultural chemicals of the Seymour aquifer, their sole source of drinking water. This concern is focused on the apparent deterioration of water quality (particularly elevated nitrate concentrations) following periods of high rainfall. Elevated levels of nitrate in the ground water of central Texas are common and have been well documented in literature. Nitrogen isotope chemistry has been applied in several attempts to find the source of the nitrate; however, the complexity of the nitrogen cycle has rendered the conclusions of these studies somewhat ambiguous. It is unknown if the source of the nitrate in the ground water of the shallow Seymour aquifer is fertilizer use, animal or human waste, or naturally occurring soil nitrogen.

OBJECTIVE: To determine if agricultural chemicals, including herbicides, insecticides, and fertilizers are present in the aquifer, and, if present, to document their distribution, movement, and fate.

The U.S. Department of Agriculture-Soil Conservation Service (USDA-SCS) began a project in fiscal year (FY) 1991 on the Haskell-Knox City segment of the Seymour aquifer with the stated goal of developing a Best Management Practices plan to reduce or eliminate existing and potential nonpointsource contamination of the ground-water. The USDA-SCS and the U.S. Geological Survey studies will complement each other as well as contribute to the data needed for the U.S. Environmental Protection Agency DRASTIC computer model, currently being used by the Texas Water Commission to conduct a Statewide assessment of ground water.

APPROACH: The study will consist of three parts: (1) A literature review of agricultural chemicals in the Seymour and similar aquifers, (2) preparation of a hydrogeologic description of the aquifer, and (3) sampling of selected wells for agricultural chemicals as well as for standard water chemistry parameters. The aquifer description will be compiled from existing data as well as from data collected for this study. Several observation/monitoring wells will be installed in the course of this project for lithologic, water quality, and aquifer-test information. Surface geophysical surveys will supplement the borehole data. Water-quality data will include analyses for pesticides currently or formerly used in the area, minor elements, nutrients, and standard water-chemistry parameters. Additionally, a limited number of samples will be collected and analyzed for determining the age of the ground water in the aquifer and for quantifying recharge. Hydrogeologic and land-use factors will be compared in an attempt to determine the source of the nitrate in the ground water, as well as any agricultural chemicals that may be present. Descriptions of the source, movement, and fate of these chemicals will be developed.

PROGRESS: The initial literature review has been completed, and 16 wells have been sampled for the constituents mentioned above. Though none of the samples contained pesticides at or above detection 
limits, nine samples were at or above the maximum contaminant level (MCL) for nitrate, one was at or above the MCL for arsenic, eight were at or above the MCL for selenium, and four were at or above the MCL for cadmium. Five observation/monitoring wells were installed. A preliminary surface electromagnetic survey was conducted to determine if ground-penetrating radar would perform in the area. Quarterly water levels were made, and all information was entered into the ground-water site inventory data base.

PLANS: FY 1993 is the last year of data collection for the project. Conduct the surface geophysical surveys (seismic refraction), sample the five monitoring wells, collect several ground water samples for age-dating, collect quarterly water levels, and continue data interpretation and analysis.

\section{PROPOSED REPORTS:}

Bartolino, J.R., Agricultural chemical contamination of a shallow aquifer system in north-central Texas: U.S. Geological Survey Water-Resources Investigations Report.

Bartolino, J.R., Distribution of radon-222 in ground water associated with a playa-lake basin, Hockley County, Texas: Journal article. 
PROJECT TITLE: Determination of Quality of Urban Storm-Water Runoff in the Dallas-Fort Worth Metroplex

PROJECT NUMBER: TX 91-139

STUDY LOCATION: North-central Texas

COOPERATING

AGENCY: North Central Texas Council of Governments

PROJECT CHIEF: Harry C. McWreath, Subdistrict Office, Fort Worth

PROJECT DURATION: May 1991 to September 1993

PROBLEM: Section 402(P) of the Water Quality Act of 1987 requires that municipalities with a population of 100,000 or more obtain permits to control the quality of their storm runoff. Final rules published in November 1990 by the U.S. Environmental Protection Agency (USEPA) require that municipalities prepare permit applications to include, among other information, the following technical data: (1) Characterization of the quantity and quality of discharge from storm-sewer outfalls during periods of dry weather; (2) characterization of the wet-weather quantity and quality of discharge from five to ten representative outfalls during three or more representative storm events; (3) determination of storm and annual pollutant loadings from each storm-sewer outfall in the reporting area; (4) characterization of rainfall and runoff conditions; and (5) characterization of the quality of water in bodies receiving storm runoff discharges and the impact of pollutants in these discharges on the receiving body, based on existing data.

OBJECTIVES: (1) Install a wet-weather monitoring network and collect quantitative data to characterize storm-water quality for representative urban land uses, (2) estimate region-wide storm event mean concentrations and annual pollutant loads of the cumulative discharges to designated receiving waters, and (3) assist in the design of a monitoring program for the life of the permit for representative data collection.

APPROACH: To undertake the investigative work according to a three-phase wet-weather storm-water monitoring plan, a regional concept for meeting the water-quality and hydrologic informational needs will be followed. The regional concept is based upon the various cities in the metroplex area cooperating in the operation of a 30-site monitoring network. The three-phase plan will provide hydrologic informational needs for: (a) Dallas and Fort Worth by November 1992; (b) Arlington, Garland, and Irving by May 1993; and (c) Plano, Mesquite, and other cities by August 1993.

PROGRESS: As of November 13, 1991, USEPA approval has been granted for 10 National Pollutant Discharge Elimination System sites in Dallas and Fort Worth. A hydraulic analysis for each site was performed and a report was made to the cities. Gage shelters have been installed for 9 of the 10 sites. One flume has been installed at a site in Dallas, with other installations scheduled in the coming weeks. Storm-water sampling instrumentation is being tested at this time, and installation is expected in the near future. Exact drainage areas have been determined for all of the Dallas sites and for two of the five Fort Worth sites. A storm-water response plan and a standard operating procedure plan are being developed at this time. The project instrumentation engineer is researching alternative instrumentation. At this time, the new hydraulic engineer/statistician is on board; the instrumentation engineer is expected. 
PLANS: As of September 3, 1991, sites for wet-weather monitoring in Dallas and Fort Worth are being selected by the respective cities. As prospective sites are chosen, they will be approved separately by the U.S. Geological Survey and the USEPA. Install and operate five wet-weather monitoring sites for each city. Collect samples at the city sites during precipitation events. Prepare samples and send them to the central laboratory in Denver for analysis. As data from analysis is received from the central lab, perform initial statistical analysis, and make estimates of constituent loadings and concentrations. Install and operate 10 additional wet-weather monitoring sites for Arlington, Garland, and Irving beginning in the second quarter of fiscal year 1992.

\section{PROPOSED REPORTS:}

Buszka, P.M., Barber, L.B., II, Schroeder, M.P., and Becker, L.D., Determination of organic compounds downstream from a treated-wastewater discharge near Dallas, Texas: U.S. Geological Survey Water-Resources Investigations Report.

McWreath, H.G., Water quality of urban storm-water runoff in the Dallas-Fort Worth, Texas area, 199192: U.S. Geological Survey Water-Resources Investigations Report. 
PROJECT TITLE: Ground-Water Quality Monitoring Program, Corps of Engineers Channel Work, Shreveport, Louisiana to Daingerfield, Texas

PROJECT NUMBER: TX 91-140

STUDY LOCATION: Big Cypress Bayou, between Caddo and Lake o' the Pines, Texas

COOPERATING

AGENCY: U.S. Department of the Army, Corps of Engineers, Vicksburg , Mississippi

PROJECT CHIEF: James R. Bartolino, District Office, Austin

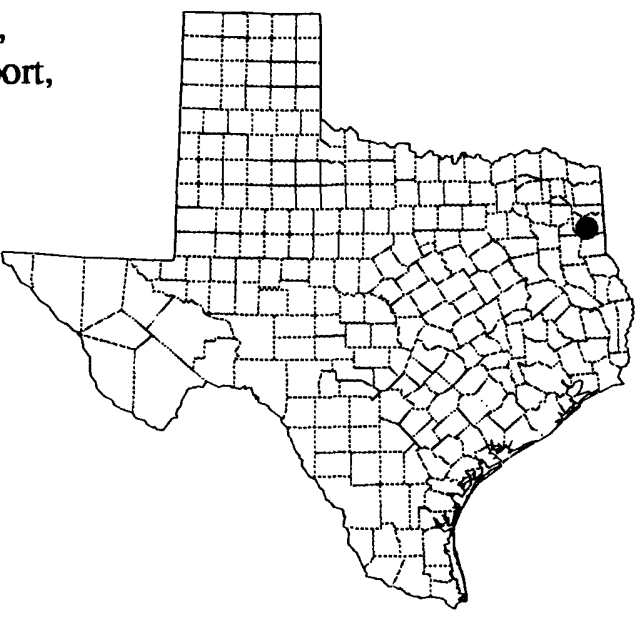

PROJECT DURATION: July 1991 to September 1993

PROBLEM: The Vicksburg, Mississippi, Division of the U.S. Army Corps of Engineers is undertaking a feasibility study for construction of a barge channelway from Shreveport, Louisiana to Daingerfield, Texas. This study will require information on geologic units, ground-water, surface-water, and groundwater quality.

OBJECTIVES: (1) To document the ground-water conditions (both water level and water quality) in and near the Big Cypress Bayou drainageway between the Texas-Louisiana State line and Daingerfield, Texas, and to provide the information to the cooperator in the form of computer data files; (2) to determine Texas regulations regarding well drilling permit requirements; (3) to offer technical advice to the cooperating agency regarding ground water in the study area; and (4) to prepare a summary groundwater quality report.

APPROACH: The U.S. Geological Survey project chief will determine Texas requirements for permitting and drilling piezometer wells. The project chief also will conduct the quarterly water-level measurements, collect the annual water-quality samples, input the data into a computerized data base, and be the chief author of the summary report.

PROGRESS: Quarterly water levels and annual water-quality samples have been collected, and all information has been inputted into the ground-water site inventory (GWSI) data base and furnished to the cooperator. The project budget was reduced by 25 percent this year, so the planned report will be diminished or eliminated, and only data will be reported to the cooperator.

PLANS: Fiscal year (FY) 1993 is the last year of the project. Continue ground-water levels and groundwater sampling. Input all data into the GWSI data base. Evaluate the data and prepare a final report.

\section{PROPOSED REPORT:}

Bartolino, J.R., Ground-water quality monitoring program, Corps of Engineers channel work, Shreveport, Louisiana to Daingerfield, Texas: U.S. Geological Survey Water-Resources Investigations Report. 
PROJECT TITLE: Regionalization of Flood Characteristics in Texas

PROJECT NUMBER: TX 91-141

STUDY LOCATION: Statewide

COOPERATING

AGENCY: Texas Department of Transportation

PROJECT CHIEF: Raymond M. Slade, Jr., District Office, Austin

PROJECT DURATION: June 1991 to September 1996

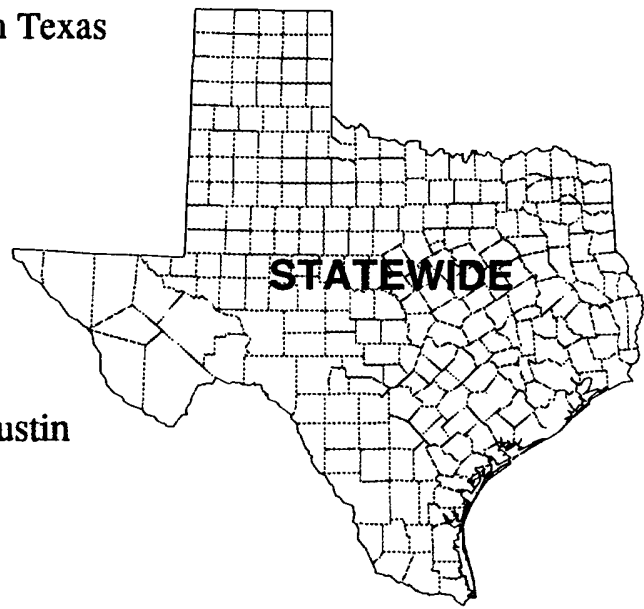

PROBLEM: The Texas Department of Transportation, Bridge Division, uses hydrologic and hydraulic information collected and published by the U.S. Geological Survey (USGS), Texas District. This information is used in the cost-effective planning and design of highway bridge and small-structure stream crossings on a Statewide basis. Information required for such projects includes site and regionalized peak discharge frequency data needed on a timely and periodic basis. There is also an increasing need for regionalized flood-hydrograph information, specific-site hydrology and hydraulics information for use in bridge-replacement planning, and information related to channel scour at bridges. To provide hydrologic and hydraulic information for transportation systems planning and design, the USGS operates a Statewide network of streamflow-gaging stations, which are cofunded by State and local agencies.

In past years, the Bridge Division has cooperated with the USGS in obtaining basic floodcharacteristics data and in providing needed analyses of these data. The work and report on the Statewide flood-frequency analyses ("Technique For Estimating The Magnitude And Frequency Of Floods In Texas," by E.E. Schroeder and B.C. Massey, U.S. Geological Survey Open-File Report 77-110) was performed in association with the Bridge Division utilizing data collected through 1974 . Floodprediction equations from this report have been used by many private and governmental entities to plan and design residential, commercial, and transportation developments throughout the State. Much new data became available in 1991 concerning sites used in the 1977 report. In the 1977 report, large areas of the Panhandle and Valley regions of Texas were noted as undefined flood-frequency regions because of a lack of basic flood information. New flood-crest gaging stations should be established in these areas and flood data should be collected. In addition, new sites are available for analysis, and the statistical techniques for analysis have improved considerably. Regional average standard errors of prediction in the 1977 report range from 35 to 50 percent. With inclusion of new data, new sites, and better statistical techniques, the error probably could be reduced significantly.

OBJECTIVES: (1) To collect flood-peak data to define the regional flood characteristics for the undefined regions in the State, (2) to update USGS files of available flood data and related basin and climatic characteristics and to perform peak discharge and flood-volume frequency analyses at all qualified gages using the best available statistical techniques, (3) to use the updated USGS data files to update general flood-peak skew values Statewide, (4) to use the flood-peak and -volume frequency data with the most pertinent basin and climatic characteristics in order to develop equations to estimate flood peaks and flood volumes for given probabilities in regions of the State, and (5) to perform a Statewide analysis to regionalize average flood-hydrograph ordinates and to prepare predictive relations for basin lag time. 
APPROACH: (1) Establish and operate about 20 flood-crest stations in undefined flood regions of the State; (2) collect rainfall and resulting stream discharge event data for at least 15 flood events at each site; (3) calibrate and verify the USGS rainfall-runoff, record-extension, and watershed simulation model at each site; (4) use calibrated site models together with available long-term rainfall event data to synthesize long-term, annual flood-peak series at each site; (5) perform frequency analysis to obtain T-year flood peaks and volumes; (6) include results in the Statewide analyses; (7) inventory and develop a data base of available flood peak, flood volume, site-generated skew, and hydrograph information for use in floodmagnitude frequency analysis and flood-hydrograph regionalization; (8) prepare updated basin and climatic characteristics for all sites in the flood-data base and perform generalized least squares (GLS) multiple regression analysis to obtain predictive equations for flood peaks, volumes, and skew; (9) determine basin physiographic characteristics with the aid of geographic information system (GIS) technology; (10) in association with the Office of Surface Water, USGS National Research Program and various Texas Universities, explore new methods of flood-frequency regionalization and at-site frequency analysis, including "index flood methods" and generalized extreme value methods with probabilityweighted moments. Comparisons will be made with traditional USGS approaches; (11) test techniques for determining homogeneous regions, including cluster analysis, and for merging index flood methods with GLS; and (12) incorporate Statewide predictive equations for flood peak, volume, and hydrograph characteristics into a microcomputer program compatible with Bridge Division software libraries. Include enhanced climatic and topographic information in the program within a GIS system for greater utility and ease of use of the flood characteristics prediction system.

PLANS: Research statistical methods for flood-frequency analyses. Determine basin and precipitation characteristics for the watersheds of all streamflow gages with at least 10 years of unregulated streamflow. Locate, install, and operate about 20 flood-crest gages in undefined flood regions of Texas. Calculate flood-peak frequencies for all gages. Calculate flood-volume frequencies for all gages.

\section{PROPOSED REPORT:}

Slade, R.M., Jr., Methods to estimate peak-streamflow frequency for floods in Texas: U.S. Geological Survey Water-Resources Investigations Report. 
PROJECT TITLE: Storm-Water Investigations in the San Antonio Metropolitan Area

PROJECT NUMBER: TX 91-142

STUDY LOCATION: Bexar County

COOPERATING

AGENCY: San Antonio Water Systems

PROJECT CHIEF: Ranko S. Pudar, Subdistrict Office, San Antonio

PROJECT DURATION: August 1991 to September 1993

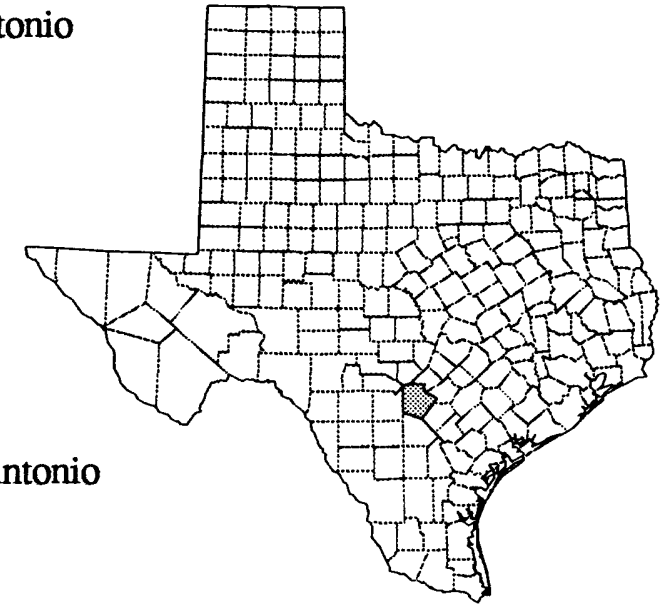

PROBLEM: In compliance with U.S. Environmental Protection Agency regulations, the city of San Antonio is required to submit National Pollution Discharge Elimination System permit applications for monitoring the quality of the urban storm-water runoff. The role of the U.S. Geological Survey in preparing applications includes collection, compilation, analysis, and publication of hydrologic data for the wet-weather conditions.

OBJECTIVES: (1) To determine the pollutant loads from representative watersheds in the San Antonio urban area, (2) to characterize the land-use impacts on water quality, (3) to supply basic information to develop management alternatives for permit compliance, and (4) to complete a final interpretive report at the conclusion of the study.

APPROACH: (1) Complete the wet-weather sample acquisition program, (2) do a detailed hydrologic and hydraulic analysis of observed watersheds, (3) develop a statistical data base for the pollutant load estimate, (4) develop a Geographical Information System data base, (5) apply statistical methods for estimation of concentration and load of 12 pollutants, (6) do a deterministic simulation of the pollutant load on selected urban watersheds, (7) design a long-term watershed monitoring program, and (8) assess and document the study.

PROGRESS: Six gaging stations have been installed. Preliminary characterization of urban basins has been completed. About 15 percent of all required samples have been collected.

PLANS: Write a report assessing the study.

\section{PROPOSED REPORT:}

Pudar, R.S., Water-quality of urban storm runoff in the San Antonio, Texas, metropolitan area: U.S. Geological Survey Water-Resources Investigations Report. 
PROJECT TITLE: Distribution of Mercury in Sediments in Lavaca and Matagorda Bays, Calhoun County

PROJECT NUMBER: TX 92-143

STUDY LOCATION: South-central Texas

COOPERATING

AGENCY: Technical Management Team, Lavaca Bay

PROJECT CHIEF: George B. Ozuna, Subdistrict Office, San Antonio

PROJECT DURATION: May 1992 to December 1992

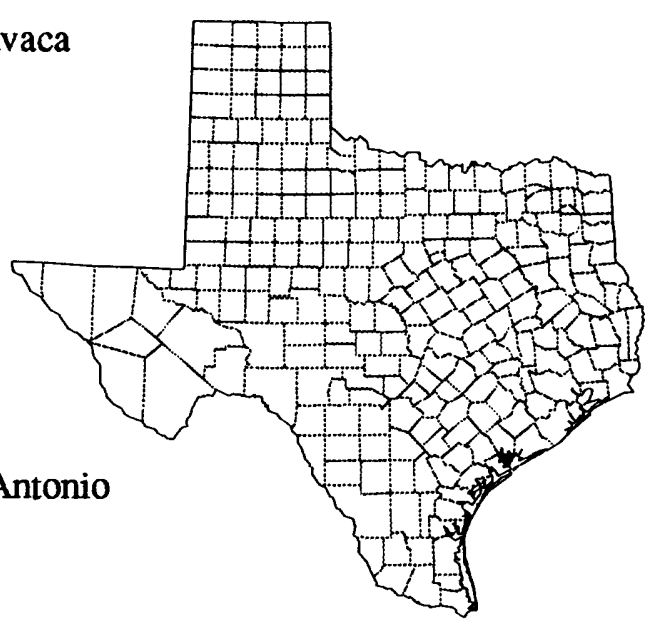

PROBLEM: Lavaca Bay is located along the central Texas Gulf Coast. It is a secondary bay associated with the Matagorda Bay estuarine system. Lavaca Bay and the surrounding area support an important commercial and sport fishing industry. Abnormally large levels of mercury are present in Lavaca Bay and in northwest Matagorda Bay sediments. Fisheries were closed in 1988 in a part of the bay because of high mercury levels in finfish, crabs, and oysters. Government trustees that compose the Technical Management Team are responsible for assessing resource damage; they include the Department of the Interior, Fish and Wildlife Service; the National Oceanic and Atmospheric Administration; the Texas Water Commission; the Texas State Parks and Wildlife Department; and the Texas General Land Office. These trustees have requested that the U.S. Geological Survey determine the present distribution of mercury in the bay sediments.

OBJECTIVE: To determine the three-dimensional mercury distribution in Lavaca and Matagorda Bays sediments.

APPROACH: Assemble and compile available data and reports that relate to the mercury present in the Lavaca Bay study area sediments. The sampling strategy will initially require geographical analysis and a field reconnaissance of the Lavaca Bay study area to define and delineate major estuarine environments that represent a discrete sediment matrix. Sampled environments will include open water, spoil island, dredge channel, reef or oyster bed, and marsh. Systematic and stratified random-sampling methods will be employed to direct the detailed sampling effort of sedimented cores within these environments. Descriptive statistics and geostatistics will be used to determine the optimum allocation of cores and samples for a second stage of effort.

PROGRESS: Sampling was completed in August 1992. All interpretations have be done. Statistics are being compiled. A preliminary report is being compiled for cooperators.

PLANS: The project will be completed.

\section{PROPOSED REPORT:}

Ozuna, G.B., Physical and chemical characteristics of mercury in sediments in Lavaca and Matagorda Bays: U.S. Geological Survey Water-Resources Investigations Report. 


\section{REPORTS PUBLISHED OR APPROVED FOR PUBLICATION IN FISCAL YEARS 1989-92}

Andrews, F.L., 1989, Monthly and annual suspended-sediment loads in the Brazos River at Richmond, Texas, 1966-86 water years: U.S. Geological Survey Water-Resources Investigations Report 884216, 20 p.

Andrews, F.L., Wells, F.C., Shelby, W.J., and McPherson, E.M., 1988, Water quality of Lake Austin and Town Lake, Austin, Texas: U.S. Geological Survey Water-Resources Investigations Report 884233, 322 p.

Ardis, A.F., and Barker, R.A., 1992, Historical saturated thickness of the Edwards-Trinity aquifer system, and selected contiguous hydraulically connected units, west-central Texas: U.S. Geological Survey Water-Resources Investigations Report 92-4125.

Barber, N.L., and Lurry, D.L., 1988, Use of computerized spreadsheets for water-use data manipulations in Proceedings on Water-Use Data for Water Resources Management: Tucson, Arizona, August 28-31, 1988.

Barber, N.L., Lurry, D.L., and Lynn, L.M., 1990, Water supply and use in National Water Summary, 1987--Hydrologic events and water supply and use: U.S. Geological Survey Water-Supply Paper 2350, p. 475-484.

Barbie, D.L., Coplin L.S., and Bonnet, C.W., 1989, Approximate altitude of water levels in wells in the Chicot and Evangeline aquifers in the Houston area, Texas, spring 1989: U.S. Geological Survey Open-File Report 89-237, 2 sheets.

1989, Approximate water-level changes in wells completed in the Chicot and Evangeline aquifers, 1977-89 and 1988-89, and measured compaction, 1973-89, in the Houston-Galveston region, Texas: U.S. Geological Survey Open-File Report 89-057, 7 sheets.

Barbie, D.L., Coplin, L.S., and Locke, G.L., 1990, Approximate water-level changes in wells completed in the Chicot and Evangeline aquifers, 1977-90 and 1989-90, and measured compaction, 1973December 1989, in the Houston-Galveston region, Texas: U.S. Geological Survey Open-File Report 90-132, 7 sheets.

1991, Approximate altitude of water levels in wells in the Chicot and Evangeline aquifers, in the Houston area, Texas, January-February 1990: U.S. Geological Survey Open-File Report 91-240, 2 sheets.

Barbie, D.L., Kasmarek, M.C., and Campodonico, Al, 1991, Approximate water-level changes in wells completed in the Chicot and Evangeline aquifers, 1977-91 and 1990-91, and measured compaction, 1973-90, in the Houston-Galveston region, Texas: U.S. Geological Survey OpenFile Report 91-94, 7 sheets.

Barbie, D.L., and Locke, G.L., 19 , Ground-water resources of the Houston district, Texas, 1985-89: U.S. Geological Survey Water-Resources Investigations Report 92-4180.

Barker, R.A., 1991, The deposition, diagenesis, and hydraulic characteristics of rocks that compose the Edwards-Trinity aquifer system of west-central Texas in Proceedings of the Annual Meeting of the Geological Society of America: San Diego, California, October 21-24, 1991.

Barker, R.A., and Ardis, A.F., 1992, Configuration of the base of the Edwards-Trinity aquifer system and hydrogeology of the underlying pre-Cretaceous rocks, west-central Texas: U.S. Geological Survey Water-Resources Investigations Report 91-4071, 24 p.

Bartolino, J.R., 1991, Radon-222 in the ground water surrounding the Anton lake basin, Hockley County, Southern High Plains of Texas in Proceedings of the Fall Meeting of the Texas State Section, American Water Resources Association: Austin, Texas, November 8, 1991, p. 65.

Brown, D.S., Petri, B.L., and Nalley, G.M., 1992, Compilation of hydrologic data for the Edwards aquifer, San Antonio area, Texas, 1991, with 1934-91 summary: Edwards Underground Water District Bulletin 51, $169 \mathrm{p}$. 
Buckner, H.D., Carrillo, E.R., Davidson, H.J., and Shelby, W.J., 1989, Water resources data, Texas, water year 1988, Volume 1. Arkansas River basin, Red River basin, Sabine River basin, Neches River basin, Trinity River basin, and intervening coastal basins: U.S. Geological Survey WaterData Report TX-88-1, 467 p.

1989, Water resources data, Texas, water year 1988, Volume 2. San Jacinto River basin, Brazos River basin, San Bernard River basin, and intervening coastal basins: U.S. Geological Survey Water-Data Report TX-88-2, 425 p.

1989, Water resources data, Texas, water year 1988, Volume 3. Colorado River basin, Lavaca River basin, Nueces River basin, Rio Grande basin, and intervening coastal basins: U.S. Geological Survey Water-Data Report TX-88-3, 425 p.

Buckner, H.D., Shelby, W.J., and Davidson, H.J., 1990, Water resources data, Texas, water year 1989, Volume 1. Arkansas River basin, Red River basin, Sabine River basin, Neches River basin, Trinity River basin, and intervening coastal basins: U.S. Geological Survey Water-Data Report TX-89-1, $499 \mathrm{p}$.

1990, Water resources data, Texas, water year 1989, Volume 2. San Jacinto River basin, Brazos River basin, San Bernard River basin, and intervening coastal basins: U.S. Geological Survey Water-Data Report TX-89-2, 412 p.

1990, Water resources data, Texas, water year 1989, Volume 3. Colorado River basin, Lavaca River basin, Nueces River basin, Rio Grande basin, and intervening coastal basins: U.S. Geological Survey Water-Data Report TX-89-3, 425 p.

Buckner, H.D., and Shelby, W.J., 1991, Water resources data, Texas, water year 1990, Volume 1. Arkansas River basin, Red River basin, Sabine River basin, Neches River basin, Trinity River basin, and intervening coastal basins: U.S. Geological Survey Water-Data Report TX-90-1, $453 \mathrm{p}$.

1991, Water resources data, Texas, water year 1990, Volume 2. San Jacinto River basin, Brazos River basin, San Bernard River basin, and intervening coastal basins: U.S. Geological Survey Water-Data Report TX-90-2, 367 p.

1991, Water resources data, Texas, water year 1990, Volume 3. Colorado River basin, Lavaca River basin, Nueces River basin, Rio Grande basin, and intervening coastal basins: U.S. Geological Survey Water-Data Report TX-90-3, 443 p.

1992, Water resources data, Texas, water year 1991, Volume 1. Arkansas River Basin, Red River Basin, Sabine River Basin, Neches River Basin, Trinity River Basin, and intervening coastal basins: U.S. Geological Survey Water-Data Report for Texas, TX-91-1, 449 p.

1992, Water resources data, Texas, water year 1991, Volume 2. San Jacinto River Basin, Brazos River Basin, San Bernard River Basin, and intervening coastal basins: U.S. Geological Survey Water-Data Report for Texas, TX-91-2, 355 p.

1992, Water resources data, Texas, water year 1991, Volume 3. Colorado River Basin, Lavaca River Basin, Nueces River Basin, Rio Grande Basin, and intervening coastal basins: U.S. Geological Survey Water-Data Report for Texas, TX-91-3, 451 p.

Busby, J.F., Plummer, L. Niel, Lee, R.W., and Hanshaw, B.B., in press, Geochemical evolution of water in the Madison aquifer in parts of Montana, South Dakota, and Wyoming: U.S. Geological Survey Professional Paper 1273-F.

Bush, P.W., Ardis, A.F., and Wynn, K.H., 1992, Historical potentiometric surface of the Edwards-Trinity aquifer system and contiguous hydraulically connected units, west-central Texas: U.S. Geological Survey Water-Resources Investigations Report 92-4055, 3 map sheets.

Buszka, P.M., Bassett, R.L., and Davidson, G.R., 1991, Use of the stable isotopic ratio of boron as a ground-water tracer near El Paso, Texas in Proceedings of the 1991 Fall Meeting of the American Geophysical Union: San Francisco, California, December 9-13, 1991. 
Buszka, P.M., Zaugg, S.D., and Werner, M.G., 1990, Determinations of trace concentrations of volatile organic compounds in ground water using closed-loop stripping, Edwards aquifer, Texas: Bulletin of Environmental Contamination 45, p. 507-515.

Coplin, L.S. and Campodonico, Al, 1991, Records or wells, drillers' logs water-level measurement, and chemical analyses of ground water in Harris and Galveston Counties, Texas, 1985-89: U.S. Geological Survey Open-File Report 90-598, 168 p.

Dunn, D.D., and Hejl, H.R., Jr., 1992, U.S. Geological Survey bridge scour evaluation program in Texas, in Saving a threatened resource--in search of solutions, Water forum '92, Hydraulic Engineering sessions, Proceedings: Baltimore, Maryland, August 2-5, 1992, American Society of Civil Engineers, p. 82-84.

Fisher, J.C., 1988, Hydrologic data for the Salt Bayou estuary near Sabine Pass, Texas, October 1984 to March 1986: U.S. Geological Survey Open-File Report 88-499, 128 p.

Gabrysch, R.K., 1991, Land-surface subsidence in the Houston-Galveston region, Texas in Guidebook of the Fourth International Symposium on Land Subsidence: Houston, Texas, May 12-17, 1991.

Gabrysch, R.K., and Coplin, L.S., 1990, Land-surface subsidence resulting from ground-water withdrawals, Houston-Galveston region, Texas, through 1987: Harris-Galveston Coastal Subsidence District Report of Investigations 90-01, $53 \mathrm{p}$.

Gain, W.S., 1989, Physical and chemical data from two water-quality surveys of streams in the Lewisville Lake watershed, north-central Texas, 1984 and 1985: U.S. Geological Survey OpenFile Report 89-258, 2 sheets.

1990, Time of travel of solutes in the Trinity River from Dallas to Trinidad, Texas, May and August 1987: U.S. Geological Survey Open-File Report 89-614, 1 sheet.

Gandara, S.C., and Buckner, H.D., 1991, Water resources data, Texas, water year 1991, Volume 4. Ground-water data: U.S. Geological Survey Water-Data Report TX-91-4, 213 p.

Gandara, S.C., Buckner, H.D., and Jones, R.E., 1992, Water resources data, Texas, water year 1992, Volume 4. Ground-water data: U.S. Geological Survey Water-Data Report TX-92-4, 359 p.

Gilbert, J.J., and Myers, D.R., 1989, Analysis of water surface and flow distribution for the design flood at a proposed highway crossing of the Sabine River near Tatum, Texas: U.S. Geological Survey Water-Resources Investigations Report 88-4231, 36 p.

Groschen, G.E., 1990, Factors influencing upconing of saline water toward wells in Proceedings of the Fall Meeting of the Texas State Section, American Water Resources Association: Austin, Texas, November 16, 1990.

1992, Barrier faults control flowpaths within the Edwards aquifer in the Balcones fault zone, San Antonio area, Texas: U.S. Geological Survey Abstract.

in press, Numerical-simulation analysis of the movement of saline water in the Hueco bolson aquifer, El Paso, Texas, and adjacent areas: U.S. Geological Survey Open-File Report (pending Water-Supply Paper) 92-171.

Jennings, M.E., Bush, P.W., and Nalley, G.M., 1992, Generalized hydrologic characteristics of the Edwards aquifer in Proceedings of the Fall Meeting of the Texas State Section, American Water Resources Association: Irving, Texas, December 4, 1992, p. 19.

Jennings, M.E., and Massey, B.C., 1992, Central Texas floods, 1921-1991 in Proceedings of the Spring Meeting of the Texas State Section, American Water Resources Association: Corpus Christi, Texas, May 22, 1992, p. 25.

Jennings, R.B., Raines, T.H., and Colangione, L.G., 1992, USGS urban stormwater investigations in the Dallas-Fort Worth, Texas metroplex in Saving a threatened resource--in search of solutions, Water forum '92, Hydraulic Engineering sessions, Proceedings: Baltimore, Maryland, August 25, 1992, American Society of Civil Engineers, p. 56-61.

Jones, B.D., 1991, Floods and droughts, Texas in National Water Summary, 1988-89--Hydrologic events and floods and droughts: U.S. Geological Survey Water-Supply Paper 2375, p. 512-520. 
Kasmarek, M.C., Barbie, D.L., and Campodonico, Al, 1992, Approximate changes in water levels in wells completed in the Chicot and Evangeline aquifers, 1977-92 and 1991-92, and measured compaction, 1973-91, in the Houston-Galveston region, Texas: U.S. Geological Survey OpenFile Report, 92-66, 7 sheets.

Kuniansky, E.L., 1989, Precipitation, streamflow, and base flow in west-central Texas, December 1974 through March 1977: U.S. Geological Survey Water-Resources Investigations Report 88-4218, 2 sheets.

1990, A finite-element model for simulation of two-dimensional steady state ground-water flow in confined aquifers: U.S. Geological Survey Open-File Report 90-187, 77 p.

1990, Potentiometric surface of the Edwards-Trinity aquifer system and contiguous hydraulically connected units, west-central Texas, winter 1974-75: U.S. Geological Survey Water-Resources Investigations Report 89-4208, 2 sheets.

in press, Estimation of aquifer recharge, Baton Rouge area, Louisiana: Ground Water.

Kuniansky, E.L., and Lowther, R.A., 1990, Finite-element mesh generation using a vector-based geographic information system in Proceedings of the Fall Meeting of the Texas State Section, American Water Resources Association: Austin, Texas, November 16, 1990.

in press, Finite-element mesh generation from mappable features: International Journal of Geographic Information Systems.

Land, L.F., 1990, District program-reporting system (DiPRS) for Texas District office of the U.S. Geological Survey: Abstract to the 1990 National Computer Technology Meeting, San Antonio, Texas, May 7-11, 1990.

1990, The U.S. Geological Survey national water-quality assessment program and Trinity River basin in Proceedings of conference on How Healthy is the Upper Trinity River, Texas Water Resources Institute: Texas A\&M University, College Station, Texas, October 2, 1990, p. 5-10.

1991, National Water-Quality Assessment program--the Trinity River basin study: U.S. Geological Survey Open-File Report 91-158, Fact Sheet, 1 p.

Land, L.F., and Dorsey, M.E., 1989, Summary of hydrologic data for the San Gabriel River basin and Edwards aquifer, Georgetown area, Texas, water year 1988: U.S. Geological Survey Open-File Report 89-226, 1 sheet.

Lee, R.W., 1991, Background aqueous chemistry of shallow ground water in a sewage-contaminated glacial outwash aquifer, Cape Cod, Massachusetts in Proceedings of the 4th Toxic Substances Hydrology Technical Meeting: Monterey, California, March 11-15, 1991, U.S. Geological Survey Open-File Report 91-88, p. 2.

1991, Background aqueous chemistry of shallow ground water in a glacial outwash aquifer, Cape Cod, Massachusetts in Proceedings (EOS) of the 1991 Fall Meeting of the American Geophysical Union: San Francisco, California, December 9-13, 1991.

Locke, G.L., 1990, Ground-water withdrawals, water-level changes, land-surface subsidence, and ground-water quality in Fort Bend County, Texas, 1969-87: U.S. Geological Survey WaterResources Investigations Report 90-4012, $155 \mathrm{p}$.

1991, Records of wells, drillers' logs, water-level measurements, and chemical analyses of ground water in Brazoria, Fort Bend, and Waller Counties, Texas 1985-89: U.S. Geological Survey Open-File Report 90-588, 40 p.

1991, Records of wells, drillers' logs, water-level measurements, and chemical analyses of ground water in Chambers, Liberty, and Montgomery Counties, Texas, 1985-89: U.S. Geological Survey Open-File Report 90-594, 45 p.

Locke, G.L., and Barbie, D.L., 1991, Approximate water-level changes in wells completed in the Chicot and Evangeline aquifers, 1990-91, in Fort Bend County, Texas: U.S. Geological Survey OpenFile Report 91-95, 2 sheets. 
Locke, G.L, and Santos, H.X., 1992, Approximate water-level changes in wells completed in the Chicot and Evangeline aquifers, 1991-92, in Fort Bend County and adjacent areas, Texas: U.S. Geological Survey Open-File Report 92-53, 2 sheets.

Lowther, R.A., and Kuniansky, E.L., 1992, Documentation of finite-element mesh-generation programs using a geographic information system: U.S. Geological Survey Water-Resources Investigations Report 92-4155, 188 p.

Lurry, D.L., and Barber, N.L., 1990, Freshwater withdrawals in Texas, 1985: U.S. Geological Survey Water-Resources Investigations Report 89-4044, 1 sheet.

Lurry, D.L., and Pavlicek, D.J., 1991, Withdrawals from the Edwards-Trinity aquifer system and contiguous hydraulically connected units, west-central Texas, December 1974 through March 1977: U.S. Geological Survey Water-Resources Investigations Report 91-4021, 1 sheet.

Maclay, R.W., and Groschen, G.E., 1992, Barrier faults control flowpaths within the Edwards aquifer in the Balcones fault zone, San Antonio area, Texas in Proceedings of the South-Central Section Meeting of the Geological Society of America: Houston, Texas, February 24-25, 1992.

Maclay, R.W., and Land, L.F., 1989, Simulation of flow in the Edwards aquifer, San Antonio region, Texas, and refinement of storage and flow concepts: U.S. Geological Survey Water-Supply Paper 2336-A, p. A1-A48.

McArthur, K.E., and Jennings, M.E., 1992, Urban storm water-quality analysis using SIMPTM in Proceedings of the Fall Meeting of the Texas State Section, American Water Resources Association: Texas Water Resources Institute, Irving, Texas, December 4, 1992, p. 39.

Nalley, G.M., 1989, Compilation of hydrologic data for the Edwards aquifer, San Antonio area, Texas, 1988, with 1934-88 summary: Edwards Underground Water District Bulletin 48, 157 p.

Nalley, G.M., and Thomas, G.M., 1990, Compilation of hydrologic data for the Edwards aquifer, San Antonio area, Texas, 1989, with 1934-89 summary: Edwards Underground Water District Bulletin 49, 155 p.

1991, Compilation of hydrologic data for the Edwards aquifer, San Antonio area, Texas, 1990, with 1934-90 summary: Edwards Underground Water District Bulletin 50, 169 p.

Ozuna, G.B., and Buszka, P.M., 1990, Installation restoration program, phase II--Confirmation/ quantification stage 3, Kelly Air Force Base, San Antonio, Texas: U.S. Geological Survey Administrative Report to the U.S. Air Force, Installation Restoration Program, 2 v.

Rast, W.R., 1991, Documentation of a data base on lake and reservoir water quality in the United States: U.S. Geological Survey Open-File Report 91-230, 76 p.

Rawson, Jack, Carrillo, E.R., and Buckner, H.D., 1989, Index of surface-water stations in Texas, January 1989: U.S. Geological Survey Open-File Report 89-265, 17 p.

Raymond, L.H., 1990, Use of remote-sensing data to map and calculate the areas of irrigated crops in south-central Texas: Abstract to the 1990 National Computer Technology Meeting, San Antonio, Texas, May 7-11, 1990.

Raymond, L.H., Nalley, G.M., and Rettman, P.L., 1992, Evaluation of the use of remote-sensing data to identify crop types and estimate irrigated acreage, Uvalde and Medina Counties, Texas, 1989:

U.S. Geological Survey Water-Resources Investigations Report 92-4117, 22 p.

Reeves, W.E., and Land, L.F., 1992, Summary of hydrologic data for the San Gabriel River basin and Edwards aquifer, Georgetown area, Texas, water year 1990: U.S. Geological Survey Open-File Report 92-160, 1 sheet.

Rettman, P.L., 1991, World's largest flowing well in Proceedings of the Fall Meeting of the Texas State Section, American Water Resources Association: Austin, Texas, November 8, 1991, p. 64.

Roddy, W.R., 1992, Water quality of the Edwards aquifer and streams recharging the aquifer in the San Antonio region, Texas: U.S. Geological Survey Hydrologic Investigations Atlas 723, 3 sheets.

Ryder, P.D., in press, Ground water atlas of the United States--Chapter E: Oklahoma and Texas: U.S. Geological Survey Hydrologic Investigations Atlas 730-E. 
Ryder, P.D., and Ardis, A.F., in press, Hydrology of the Texas Gulf Coast aquifer system: U.S. Geological Survey Professional Paper 1416-E.

Schertz, T.L., 1990, Trends in water-quality data in Texas: U.S. Geological Survey Water-Resources Investigations Report 89-4178, $177 \mathrm{p}$.

Schertz, T.L., Alexander, R.B., and Ohe, D.J., 1991, The computer program estimate trend (ESTREND), a system for the detection of trends in water-quality data: U.S. Geological Survey WaterResources Investigations Report 91-4040, $63 \mathrm{p}$.

Sisolak, J.K., 1992, Statistical analysis of urban stormwater constituents in the Dallas-Fort Worth metroplex NPDES study in Proceedings of the Fall Meeting of the Texas State Section, American Water Resources Association: Texas Water Resources Institute, Irving, Texas, December 4, 1992, p. 27.

Slade, R.M., Jr., 1989, Potential effects of a proposed recharge-enhancement reservoir on water levels in the Edwards aquifer near Austin, Texas in Proceedings of the 9th Annual North American Lake Management Society Symposium on Lake and Reservoir Management: Austin, Texas, November 7-11, 1989.

1990, Streamflow discharges to the Gulf of Mexico from the United States, [abs.]: America's Sea: U.S. Environmental Protection Agency, The environmental and economic status of the Gulf of Mexico, New Orleans, Louisiana, December 2-5, 1990.

1991, Use of skew coefficients of annual-maximum streamflow to estimate flood frequencies in Texas in Proceedings of the Fall Meeting of the Texas State Section, American Water Resources Association: Austin, Texas, November 8, 1991, p. 32.

1992, Measurement of streamflow discharge by indirect methods in Proceedings of the Spring Meeting of the Texas State Section, American Water Resources Association: Corpus Christi, Texas, May 22, 1992, p. 79.

1992, Potential effects of a proposed recharge-enhancement reservoir on the potentiometric surface of the Edwards aquifer in the Austin area, Texas in Proceedings of the Fall Meeting of the Texas State Section, American Water Resources Association: Texas Water Resources Institute, Irving, Texas, December 4, 1992, p. 8.

19 , Status of the Gulf of Mexico: Preliminary report on streamflow: U.S. Geological Survey Administrative Report to the freshwater inflow subcommittee of the Gulf of Mexico Program, U.S. Environmental Protection Agency.

Slade, R.M., Jr., and De La Garza, Laura, 1989, Increases in concentrations of dissolved solids of inflows to Lake Buchanan, Texas, as a result of releases from Natural Dam Lake, 1986-88 in Proceedings of the 9th Annual North American Lake Management Society Symposium on Lake and Reservoir Management: Austin, Texas, November 7-11, 1989.

Small, Ted, and Ozuna, G.B., 19 , Ground-water conditions in Pecos County, Texas, 1987: U.S. Geological Survey Water-Resources Investigations Report 92-4190.

Stein, W.G., 1991, Hydrogeologic surface characteristics of the Edwards aquifer recharge zone in northern Bexar County, Texas in Proceedings of the Annual Meeting of the Geological Society of America: San Diego, California, October 23, 1991.

Tan, L.L., and Jennings, M.E., 1992, Calculation of urban stormwater quality in the Dallas-Fort Worth, Texas area in Proceedings of the Spring Meeting of the Texas State Section, American Water Resources Association: Corpus Christi, Texas, May 22, 1992, p. 99.

Thornton, J.A., and Rast, W.R., in press, Application of eutrophication modeling techniques to manmade lake in semiarid southern Africa: Joumal of North American Lake Management Society.

Veenhuis, J.E., 1989, Statistical analysis of water quality in stormflow and base flow for streams in the Austin area, Texas in Proceedings of the National Symposium on Water Quality: Orlando, Florida, November 12-17, 1989. 
1991, Statistical characteristics of stormflow and baseflow quality for streams in the Austin area, Texas in Proceedings of the Fall Meeting of the Texas State Section, American Water Resources Association: Austin, Texas, November 8, 1991, p. 4.

in press, Texas stream-water quality, 1990-91 National Water Summary: U.S. Geological Survey Water-Supply Paper 2400.

Veenhuis, J.E., and Slade, R.M., Jr., 1990, Relation between urbanization and water-quality of streams in the Austin area, Texas: U.S. Geological Survey Water-Resources Investigations Report 90-4107, $64 \mathrm{p}$.

Wells, F.C., 1991, Trends in surface-water quality in the Trinity River basin, Texas, 1975-86, in Proceedings of conference on How healthy is the Upper Trinity River, Texas Water Resources Institute: Texas A\&M University, College Station, Texas, October 2, 1990, p. 103-112.

Wells, F.C., Gibbons, W.J., and Dorsey, M.E., 1990, Guidelines for collection and field analysis of water-quality samples from streams in Texas: U.S. Geological Survey Open-File Report 90-127, 79 p.

White, D.E., and Sladek, G.J., 1990, Summary of data from the 1981-83 pilot study and 1985-89 operations of the Hueco bolson recharge project, northeast El Paso, Texas: U.S. Geological Survey Open-File Report 90-175, 38 p.

Williams, J.F., III, Coplin, L.S., Ranzau, C.E., Jr., Lind, W.B., Bonnet, C.W., and Locke, G.L., 1988, Records of wells, drillers' logs, water-level measurements, and chemical analyses of ground water in Harris and Galveston Counties, Texas, 1980-84: Texas Water Development Board Report 310, 247 p.

Woodward, D.G., 1989, Flow patterns in regional aquifers and flow relations between the lower Colorado River valley and regional aquifers in six counties of southeastern Texas: U.S. Geological Survey Water-Resources Investigations Report 88-4154, 24 p. 


\title{
WHERE TO OBTAIN U.S. GEOLOGICAL SURVEY PUBLICATIONS
}

Current releases are described in a monthly catalog, "New Publications of the Geological Survey." You may have your name added to the mailing list and receive the monthly catalog free. Write to:

$$
\begin{aligned}
& \text { Mailing List Unit } \\
& \text { U.S. Geological Survey } \\
& \text { 582 National Center } \\
& \text { Reston, VA } 22092
\end{aligned}
$$

Professional Papers, Bulletins, Water-Supply Papers, Techniques of Water Resources Investigations, Circulars, Earthquake Information Bulletins, and popular leaflets, pamphlets, and booklets may be purchased from:

\author{
U.S. Geological Survey \\ Books and Open-File Reports Section \\ Federal Center \\ Box 25425, Mail Stop 517 \\ Denver, CO 80225-0425
}

Flood-prone area maps may be examined at the District Office. Open-File, Water-Resources Investigations (published after May 1982), and Open-File and Water-Resources Investigations (published before May 1982) reports are available for examination at the office from which the report originated and at the Texas District office in Austin, or they may be purchased through:

U.S. Geological Survey

Books and Open-File Reports Section

Federal Center

Box 25425 Mail Stop 517

Denver, CO 80225-0425

Maps, bench marks (vertical and horizontal), and aerial photographs are available from:

Maps

U.S. Geological Survey

Map Sales

Denver Federal Center

Box 25286, Mail Stop 206

Denver, CO 80225-0286

Bench Marks

U.S. Geological Survey

Geodetic Unit

Box 25046, Mail Stop 506

Denver Federal Center

Denver, CO 80225-0046

Aerial photographs

Earth Science Information Center

U.S. Geological Survey

Box 25046, Mail Stop 504

Denver Federal Center

Denver, CO 80225-0046 
Requests for miscellaneous information on water and on programs in other States may be referred to :

$$
\begin{gathered}
\text { Earth Science Information Center } \\
\text { U.S. Geological Survey } \\
503 \text { National Center } \\
\text { Room 4-A } 100 \\
12201 \text { Sunrise Valley Drive } \\
\text { Reston, VA } 22092
\end{gathered}
$$

The Geological Survey National Center maintains a library with an extensive earth-science collection. Local libraries may obtain books, periodicals, and maps through interlibrary loan by writing to:

$$
\begin{gathered}
\text { U.S. Geological Survey Library } \\
950 \text { National Center } \\
\text { Room 4-A100 } \\
\text { 12201 Sunrise Valley Drive } \\
\text { Reston, VA } 22092
\end{gathered}
$$

Individual topographic quadrangle maps are shown on "State Indexes to Topographic Maps," which are free on application. These indexes also show commercial dealers in each State.

Maps for all areas including Puerto Rico, the Virgin Islands, Alaska, Hawaii, Guam, and American Samoa may be ordered from:

$$
\begin{gathered}
\text { Distribution Branch } \\
\text { U.S. Geological Survey } \\
\text { Denver Federal Center, Box } 25286 \\
\text { Denver, CO } 80225-0286
\end{gathered}
$$

Book reports of the Geological Survey are available over the counter at the following U.S. Geological Survey Office, which is an authorized agent of the Superintendent of Documents:

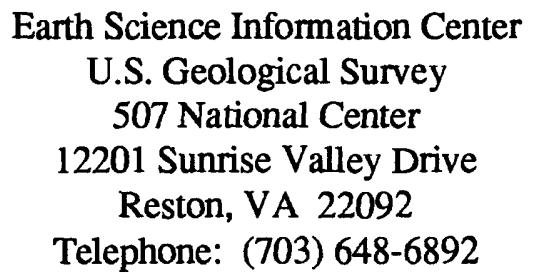

Topographic maps of Texas may be examined at:

$$
\begin{aligned}
& \text { U.S. Geological Survey } \\
& \text { Texas District Office } \\
& 8011 \text { Cameron Road } \\
& \text { Austin, TX 78754-3898 }
\end{aligned}
$$

